\title{
Current and Future Issues in the Development of Spinal Agents for the Management of Pain
}

Tony L. Yaksh", Casey J. Fisher, Tyler M. Hockman and Ashley J. Wiese

University of California, San Diego, Anesthesia Research Lab 0818, 9500 Gilman Dr. LaJolla, CA 92093, USA

\begin{abstract}
Targeting analgesic drugs for spinal delivery reflects the fact that while the conscious experience of pain is mediated supraspinally, input initiated by high intensity stimuli, tissue injury and/or nerve injury is encoded at the level of the spinal dorsal horn and this output informs the brain as to the peripheral environment. This encoding process is subject to strong upregulation resulting in hyperesthetic states and downregulation reducing the ongoing processing of nociceptive stimuli reversing the hyperesthesia and pain processing. The present review addresses the biology of spinal nociceptive processing as relevant to the effects of intrathecally-delivered drugs in altering pain processing following acute stimulation, tissue inflammation/injury and nerve injury. The review covers i) the major classes of spinal agents currently employed as intrathecal analgesics (opioid agonists, alpha 2 agonists; sodium channel blockers; calcium channel blockers; NMDA blockers; GABA A/B agonists; COX inhibitors; ii) ongoing developments in the pharmacology of spinal therapeutics focusing on less studied agents/targets (cholinesterase inhibition; Adenosine agonists; iii) novel intrathecal targeting methodologies including gene-based approaches (viral vectors, plasmids, interfering RNAs); antisense, and toxins (botulinum toxins; resniferatoxin, substance P Saporin); and iv) issues relevant to intrathecal drug delivery (neuraxial drug distribution), infusate delivery profile, drug dosing, formulation and principals involved in the preclinical evaluation of intrathecal drug safety.
\end{abstract}

\section{A R T I C L E H IS T O R Y}

Received: July 22, 2015

Revised: December 02, 2015

Accepted: February 05, 2016

DOI:

10.2174/1570159X14666160307145 542

Keywords: Adenovirus transfection, dorsal horn, neurotoxins, pain pathways, spinal drug delivery, spinal analgesics, toxicity.

\section{RATIONALE}

Targeting analgesic drugs for direct spinal delivery reflects the fact that while the conscious experience of pain is mediated supraspinally, input initiated by high intensity stimuli, tissue injury and/or nerve injury is encoded at the level of the spinal dorsal horn. Thus, high intensity (e.g., nociceptive) stimulation activates populations of small primary afferents, generating an intensity-dependent increase in activity of second order dorsal horn projection neurons. This excitation is transmitted through spinofugal projection pathways to higher centers, such as the somatosensory thalamus - somatosensory cortex, and to the medial thalamus - limbic cortices that are respectively believed to underlie the sensory-discriminative and affectivemotivational components of the pain experience [1-3]. The dorsal horn encoding process reflects a remarkable plasticity wherein the input-output function of the spinal dorsal horn is subject to pronounced regulation by local neuronal and nonneuronal circuits as well as supraspinal (bulbospinal) input. Thus, following tissue or nerve injury there is an enhanced neuronal response to moderate or low intensity stimuli, e.g.,

\footnotetext{
*Address correspondence to this author at the University of California San Diego, Anesthesia Research Lab 0818, 9500 Gilman Dr. LaJolla, CA 92093, USA; Tel: 619-543-3597; Fax: 619-543-6070;

E-mail: tyaksh@ucsd.edu
}

a right shift in the stimulus intensity-neuronal response curve. Accordingly, the spinal outflow generated by a given stimulus of moderate or low intensity following tissue and nerve injury generates an enhanced activation of supraspinal systems [4-6] and an enhanced pain state, e.g., hyperalgesia and allodynia [7], respectively. Accordingly, regulation of the spinal input-output function can alter the supraspinally organized pain experience. The organization of the inputoutput function of the spinal dorsal horn and its associated pharmacology has been the subject of extensive investigation and review [8,9]. The associated pharmacology of this processing as defined by studies of spinal physiology and behavior after spinal drug delivery has permitted targeting drugs at specific components to alter the content of the spinofugal transmission. While many analgesic drugs may be given systemically to exert their spinal action, the specific use of the intrathecal or epidural route for analgesic drug delivery may be employed for three reasons: i) the drug target lies at the spinal level (opiates, baclofen); ii) the agent does not penetrate the blood brain barrier (antisense, toxins); and/or iii) the agent penetrates the blood brain barrier but does so at systemic doses that produce undesirable side effects, so spinal delivery increases the therapeutic index (e.g., baclofen and opiates).

The efficacy of spinal drugs administered for the management of pain syndromes is dependent on the pharmacology of the underlying mechanisms that mediate 
the particular pain state. Pain states can be broadly categorized as those initiated by an acute noninjurious stimulus, those arising from tissue injury and inflammation and those secondary to nerve injury. Although the source of the pain state may be distinguishable, many clinical pain states likely reflect a combination of mechanisms; and, increasing evidence has pointed to overlapping components at the level of the primary afferent and spinal dorsal horn. These mechanisms and their associated pharmacology and biology have been extensively reviewed elsewhere $[10,11]$. In this discussion we will focus on the lumbar intrathecal route of drug delivery and consider: i) ongoing developments in the pharmacology of spinal therapeutics focusing on agents/targets that have been employed and shown to a varying degree to have efficacy in humans, ii) novel targeting methodologies and iii) several issues relevant to intrathecal drug delivery.

\section{SPINAL THERAPEUTIC TARGETS}

Spinal analgesic agents may target the primary afferent, the second order neurons, bulbospinal projections and nonneuronal components. From a practical standpoint, many of these pharmacologic targets lie within the parenchyma of the dorsal horn and emphasize that after intrathecal delivery, the topically delivered agents (such as opiates, alpha2 agonists, targeted toxins, and transfection agents targeting $2^{\text {nd }}$ order neurons) must penetrate from the CSF through the pia and then up to several hundred microns in the parenchyma or more to reach these dorsal horn sites to exert their action. These issues will be discussed further below. In other cases, the agent may target the dorsal root ganglion cell (e.g., antisense, viral vectors). This target lies distal to the dural cuff formed by the meninges $[12,13]$ and is consistent with the fact that the DRG lies outside the blood brain barrier as evidenced by movement of large molecules into the DRG from the blood [14] and by the sympathetic innervation of the DRG vasculature [15]. The necessity to move from the CSF to the DRG for a drug to reach its effect site represents a barrier for spinally administered drugs.

\section{CURRENT SPINAL AGENTS}

In this section, we will review families of agents that have been employed in humans for the management of spinal nociceptive processing. In each case we will consider the preclinical and clinical work with intrathecal delivery, mechanisms, typical molecules, adverse events with an emphasis on the work considering local drug toxicity and finally future areas of target and drug development.

\section{Opioids}

\section{Spinal Opioids}

Intrathecal delivery of opioids in amphibia and in mammals (from mouse to primate) $[16,17]$ reliably attenuate the response to noxious somatic and visceral stimuli that otherwise evoke an organized escape behavior with minimal effects upon light touch or proprioception [18].

\section{Mechanisms of Action}

Agonist action at the mu opioid receptor leads to hyperpolarization of neuronal membranes through activation of inwardly rectifying $\mathrm{K}+$ channels and depression of excitatory neurotransmitter release from the presynaptic nerve terminal by blocking the opening of voltage sensitive $\mathrm{Ca}++$ channels (VSCC), both of which serve to inhibit nociceptor neuronal activation [19]. Receptor autoradiography and histochemistry has shown that mu binding and protein are limited to the substantia gelatinosa, the region in which small afferents show their principal termination, and to small, TRPPV1 $(+)$ dorsal root ganglion cells [20, 21]. The presynaptic action blocking the opening of VSCCs leads to an inhibition of transmitter release from the nociceptive afferents and suppression of excitability in the second order neurons [17, 18]. Local delivery of opiates (delivered systemically in spinal transected animals, or by intrathecal, topical or iontophoretic methods) in the spinal cord selectively depresses discharge of spinal dorsal horn neurons activated by small ( $\mathrm{C}$ high threshold) but not large ( $\mathrm{A} ß$ low threshold) afferents [22-25] and blocks release of substance $P$ from $C$ polymodal nociceptors $[26,27]$. At the spinal level $\mu$ opioids depress the bladder reflex arc, accounting for urinary retention [28]. Other effects such as sedation or depression of the $\mathrm{CO} 2$ response curve accounting for respiratory depression are mediated by a supraspinal action [29, 30]. Chronic spinal infusion of opiates in animal models shows clear loss of effect with continued exposure (e.g., tolerance) $[31,32]$, although the magnitude of this tolerance effect with continuous spinal infusion in man has been debated [33-36].

\section{Drug Molecules}

While morphine is the only FDA-approved drug for intrathecal administration, other opioids have been used for chronic intrathecal infusion including hydromorphone, methadone, and fentanyl/sufentanil [37]. With respect to neuraxial administration, the hydrophilic nature of morphine makes it a particularly useful drug for this route of administration as systemic uptake and thus potential side effects are delayed. As a comparison for these opioids, octanol/water partition co-efficients(cLogP) are morphine: 0.9,hydromorphone: 1.6; Fentanyl: 3.8; Methadone; 4.0; Sufentanil: 4.2. In general higher cLogP values result in more rapid clearance from the intrathecal space (by meningeal and vascular uptake) and correspondingly shorter durations of action [38-40]. The hydrophilic nature of morphine accounts in part for its long residence time in the spinal space and for a comparatively long duration of action thereby making bolus drug delivery a useful means for intrathecal delivery.

\section{Adverse Events}

Following intrathecal opiates, clinically significant sedation, altered mental status, nausea/vomiting, respiratory depression [41, 42] and these end points are considered to represent supraspinal mu opioid receptor activation [43]. Urinary retention is mediated by a spinal effect upon sacral $\mathrm{mu}$ receptors (e.g., produce by mu opiates and reversed by naloxone) of the bladder-spinal bladder reflex secondary to a suppression of small afferent input and increased external sphincter tone [44-46]. Pruritus can be mediated by a peripheral, nonopioid receptor mediated effect on mast cells degranulation (e.g., not naloxone reversible and with a minimal effect of agents such as fentanyl and sufentanil in 
contrast to morphine and hydromorphone [47] and by an action upon mu receptors in a hypothesized brain stem site [48]. From a toxicological perspective, preclinical large animal safety studies have shown no significant effect upon spinal morphology, but has revealed the formation of intrathecal granulomas (e.g., an aseptic space-occupying mass proximal to the catheter tip composed of inflammatory cells that have migrated from the meninges) to be associated with the intrathecal infusion of high concentrations of morphine, hydromorphone and methadone, but not alfentanil or fentanyl) [49-55] but see [56]. Preclinical work has shown that in accord with the lack of an opiate structure activity relationship (e.g., granuloma inducing potency: morphine $>$ fentanyl), the granuloma formation was not prevented by concurrent opiate receptor antagonism [54]. Preclinical work has pointed to the potential role of meningeal mast cell degranulation in granuloma formation [54]. In humans, comparable intrathecal masses have been observed after continuous infusion of high concentrations of most opioids including morphine and hydromorphone, but less so with fentanyl $[53,57]$.

\section{Future Directions for Spinal Opiates}

The pharmacodynamics of mu receptors has proven to be complex and suggest several promising avenues for future development: i) Mu opioid receptors occur as splice variants. Efforts have been made to develop ligands targeted at these splice variants $[58,59]$. ii) $\mathrm{Mu}$ receptors couple through Gi/o protein in a $\beta$ arrestin dependent fashion such that ligand occupancy yields receptor internalization and desensitization of $\mathrm{G}$ protein signaling $[60,61]$. Activation of mu receptors can be achieved separately from $\beta$ arrestin signaling. Such "G protein biased" ligands are believed to yield increased analgesic efficacy compared to other $G$ protein-coupled receptors [62]. iv) Current work suggests that many G protein coupled receptors may form homo- and heterodimers [63]. Bivalent ligands interacting with these hetero-dimers, such as mu and delta receptors, have demonstrated enhanced cellular responses [64]. Thus, a mu agonist and a delta antagonist ligand display enhanced efficacy and a reduced propensity for tolerance [65]. Heterodimers constructed from opioid and nonopioid binding sites, such as bivalent $\mathrm{Mu}$ CB1 (cannabinoid) [66] or $\mu$-mGluR5 (metabotrophic glutamate receptors) $[67,68]$, have potent antihyperalgesic effects in avariety of models. v) Agents with delta opioid preference (e.g., the effects of which are antagonized by naloxone and naltrendole) have been shown to have a spinal analgesic action in preclinical models when given intrathecally as a bolus [69-74]; or an infusion [75, 76]. This work is consistent with the presence of delta opioid receptors presynaptic on subpopulations of small primary afferents which regulate the activity of thermal and/or mechanical nociceptor [77-79] and block of release of small spinal afferent peptides [26, 69, 80-82]. One agent administered intrathecally, DADL (d-ala2-d-leu5 enkephalin), was shown to have efficacy in humans $[83,84]$. These agents have been shown to not display cross-tolerance to mu opiates $[75,76]$. vi) As noted above, one current hypothesis regarding granuloma formation is that it may relate to a concentration dependent degranulation of mast cells that is not mediated by an opiate receptor [54]. This dissociation suggests the possibility that agents that do not result in mast cell degranulation at concentration necessary for opiate receptor activation and have intrathecal kinetics similar to morphine might provide an alternative approach to defining an alternative to the currently available opiates. Potential molecules might for example be potent mu or delta opioid peptides $[85,86]$.

\section{Alpha 2 Agonists \\ Spinal Alpha 2 Agonists}

Alpha $2\left(\alpha_{2}\right)$ agonists administered intrathecally have been shown to have efficacy in a variety of animal pain models including those associated with acute tissue injury and neuropathic pain states $[87,88]$.

\section{Mechanisms of Action}

Three relevant subclasses of $\alpha_{2}$ agonists, $\alpha_{2 \mathrm{~A}}, \alpha_{2 \mathrm{~B}}, \alpha_{2 \mathrm{C}}$, have been shown [89]. In situ studies have shown that subtype messages are present in sensory neurons: $\alpha_{2 \mathrm{C}},>\alpha_{2 \mathrm{~A}}$, $>\alpha_{2 B}$, whereas in spinal dorsal horn the message levels are: $\alpha_{2 \mathrm{~B}}>\alpha_{2 \mathrm{C}}>\alpha_{2 \mathrm{~A}}$ [90]. Interestingly, discrepancies are noted between the $\alpha_{2}$ subtypes as defined by message and immunohistochemistry (see [91]). Spinal $\alpha_{2}$ adrenergic receptors display several characteristics: i) binding is present presynaptically on C-fibers and postsynaptically on spinal neurons; ii) agonists are believed to alter spinal nociceptive processing by preventing opening of voltage-sensitive $\mathrm{Ca}$ channels (blocking release) $[92,93]$ and increasing potassium conductance leading to hyperpolarization of dorsal horn neurons through increased pK conductance [87, 88, 94, 95]. Consistent with their pharmacology, the analgesic activity is reversed by $\alpha_{2}$ antagonists such as atipamezole [96-98]. At the spinal level, $\alpha_{2}$ agonists reduce preganglionic sympathetic outflow, accounting in part for their hypotensive actions, while sedation is mediated supraspinally [99]. A similar mechanism of action to opioids is noted, albeit through distinctly different receptors that are often co-localized. Tolerance with repeated exposure has been reported, but cross-tolerance with mu opioids does not occur $[100,101]$.

\section{Drug Molecules}

Dexmedetomidine, clonidine, and xylazine are $\alpha_{2}$ agonists used systemically in human and veterinary clinical practice, however, clonidine is the only $\alpha_{2}$ agonistwith FDA approval for spinal (epidural) delivery in humans. Perhaps not surprisingly, the addition of clonidine to neuraxial morphine enhances analgesic efficacy $[102,103]$.

\section{Adverse Events}

The use of $\alpha_{2}$ agonists such as clonidine is largely limited by sedation, systemic hypotension, and bradycardia that are likely produced by a central sympatholytic effect and activation of $\alpha_{2 \mathrm{~A}}$ in the medulla. Chronic epidural [104] and limited intrathecal large animal [49] preclinical safety work has shown no evidenceof spinal toxicity.

\section{Future Directions for Spinal Alpha 2 Agonist}

While some work has suggested that analgesia and sedation may be separable if different sub-classes of $\alpha_{2}$ receptors can be targeted $[98,105,106]$, such differentiation 
is not supported by studies in gene-altered mice [107], and the work has not led to definitively distinguishable agents. The cLogP of clonidine (2.6) and dexmedetomidine (3.0) reflect upon the short duration of action and rapid systemic exposure that occurs with these spinal agents suggesting that a more polar $\alpha_{2}$ agonist might have virtue.

\section{Spinal Sodium Channel Blockers}

\section{Spinal Antagonists}

The original drugs employed for spinally directed therapy were cocaine and derivatives $[108,109]$. Those incredibly insightful studies performed over 100 years ago defined the potent anesthetic and motor block produced by intrathecal cocaine and the residual presence of analgesia to pain and temperature [110]. Preclinical studies have typically shown minimal effects upon acute nociception at sub-motor impairing doses of conventional sodium channel blockers given intrathecally. However, they are reported to reliably result in a remarkable analgesic synergy with intrathecal agents such as opiates or alpha 2 agonists with minimal attendant effects upon motor function in animal models [111-114] and in humans [115-117]. There is a clinical literature that suggests that neuraxial local anesthetics may display a tachyphylaxis with chronic exposure that may respond to different local anesthetics [118]. However, systematic clinical evidence of this impression is controversial (see [119]. Nerve block studies do not display such changes, suggesting that if tachyphylaxis does occur it reflects some system level change [120].

\section{Mechanisms of Action}

The common mechanism of all clinically employed "local anesthetics" is to block the voltage-gated sodium channel $\left(\mathrm{Na}_{\mathrm{v}}\right) \cdot \mathrm{Na}_{\mathrm{v}} \mathrm{s}$ consist of an $\alpha$-subunit complex that forms the transmembrane spanning pore and auxiliary $\beta$ subunits [121]. The channel expresses molecular components mediating the voltage sensing and gating elements that result in the voltage-dependent opening and voltage-independent closing of the channel. Importantly, the typical anesthetic with $\mathrm{pKa}>7.4$ is unionized at extracellular physiological $\mathrm{pHs}$, penetrates the membrane, reionizes in the more acidic intracellular environment and in the ionized (protonated) state blocks the channel from the intracellular side. Several general properties of the block are appreciated. The differential block of motor axons and low vs. high threshold sensory afferents reflect the greater sensitivity of small vs. large afferents to block of the conducted action potential. As local anesthetics bind to sodium channels in an activated state, the initiation of blockade is facilitated in neurons discharging at a high frequency (e.g. a state-dependent block [122-124]. Previous speculations [112] have pointed to the role of impedance mismatching at the extensive afferent branch points within the dorsal horn. This would lead to an increased probability of conduction failure in the small (Cfiber) afferents [125] and an increased susceptibility of the terminal depolarization to be blocked by low concentrations of local anesthetics.

Nine isoforms have been identified with distinguishable activation properties and tissue distributions [126]. Of particular note, $\mathrm{Na}_{\mathrm{v}} 1.4$ and $\mathrm{Na}_{\mathrm{v}} 1.5$ are present in skeletal and cardiac myocytes. $\mathrm{Na}_{\mathrm{v}} 1.7, \mathrm{Na}_{\mathrm{v}} 1.8$, and $\mathrm{Na}_{\mathrm{v}} 1.9$ are predominantly expressed in small sensory DRGs/afferents, while $\mathrm{NaV} 1.1$ and 1.6 are found more highly expressed in large DRG/axons [127]. Clinically employed local anesthetics (amide and ester) are essentially non-selective in their blocking of different sodium channels (see [124]). Several sodium channel isoforms are sensitive to the puffer fish toxin, tetrodotoxin (TTX) $\left(\mathrm{Na}_{\mathrm{v}} 1.1, \mathrm{Na}_{\mathrm{v}} 1.2, \mathrm{Na}_{\mathrm{v}} 1.3\right.$, $\mathrm{Na}_{\mathrm{v}} 1.4, \mathrm{Na}_{\mathrm{v}} 1.6$, and $\left.\mathrm{Na}_{\mathrm{v}} 1.7\right)$, while others $\left(\mathrm{Na}_{\mathrm{v}} 1.5, \mathrm{Na}_{\mathrm{v}} 1.8\right.$, and $\left.\mathrm{Na}_{\mathrm{v}} 1.9\right)$ are resistant to TTX [124, 128]. Importantly, following chronic inflammation and peripheral nerve injury, prominent increases in the expression of small afferent $\mathrm{Na}_{\mathrm{v}} \mathrm{S}$ has been noted and such increases appear to be associated with the initiation of ongoing (ectopic) afferent traffic [129]. The use of antisense, siRNA and murine mutations have indicated that impairment of $\mathrm{Na}_{\mathrm{v}} 1.3,1.7,1.8$ and 1.9 expression has varying antihyperpathic effects in models of inflammatory and neuropathic pain states $[127,130,131]$. Specific gain and loss of function mutations in the $\mathrm{Na}_{\mathrm{v}} 1.7$ channels have been identified in humans wherein there is an increased and decreased pain state, respectively $[132,133]$.

\section{Drug Molecules}

Avariety of local anesthetics are employed with two common structural motifs: Hydrophobic (aromatic residue) and hydrophilic (tertiary or secondary amines) domains separated by an ester procaine, 2-chlorprocaine, tetracaine) or amide (lidocaine, bupivacaine, ropivacaine) linkage. The principal differences between drugs being use dependency, effective concentrations and duration of action. Though differences in relative potency with respect to blocking different $\mathrm{Na}_{\mathrm{v}}$ subtypes have been reported, such selectivity remains controversial and in part reflect variation in on and off rates of binding and channel opening and inactivation properties rather than a specific difference in $\mathrm{Na}_{\mathrm{v}}$ affinity $[123,124]$. The properties of local anesthetic actions at the channel have been extensively reviewed elsewhere [134, 135].

\section{Adverse Events}

Adverse events such as motor weakness and anesthesia after intrathecal delivery of currently employed local anesthetics reflect side effects related to the block of the several voltage-gated channels associated with large sensory and motor axons and spread of the block to higher centers (e.g. "total spinals") and to non-neuraxial tissues such as cardiac myocytes. As noted, the large axons are relatively resistant to conduction block. Neurological signs secondary to intrathecal local anesthetics have been identified in patients with uncomplicated spinal anesthesia wherein distal lower extremity pain was reported. Transient neurologic symptoms were reported with relative risk being higher for lidocaine compared to bupivacaine, prilocaine, procaine and mepivacaine [136]. Preclinical safety evaluations with intrathecal local anesthetics such as lidocaine, bupivacaine and ropivacaine have been marked initially by mitochondrial vacuolization, mild focal edema, with evidence of change in the lamellar structure of fibers and Schwann cells in rat and dog models $[137,138]$. The molecular mechanisms of the 
local anesthetic toxicity are not understood. Work with intrathecal TTX has shown that long-lasting sodium channel block itself is not associated with a specific toxicity [139]. Small local anesthetic molecules can have effects on lipid membrane components, which reflect the detergent nature of these amphiphillic molecules [140]. Though the mechanisms are not understood, the afferent toxicity does appear to be associated with increased intracellular calcium in the DRG [141].

\section{Future Directions for Spinal Sodium Channel Blockers}

The current advances in our understanding of the $\mathrm{Na}_{\mathrm{v}}$ subtypes and their differential distribution in the body and particularly in the neuraxis, as well as the upregulation in their expression after injury leading to ectopic activity and increased neuronal excitability, offers evident opportunities for creating drugs that target those elements that might be most altered by the pain states. Several strategies have been employed. As reviewed elsewhere, there has been a great deal of effort to define structures that prefer one channel over another $[142,143]$. Preclinical work with intrathecallydelivered molecules targeted at $\mathrm{Na}_{\mathrm{v}} 1.7$ [144] and 1.8 [145] has shown preclinical efficacy. While much attention has been paid to the TTX-resistant sodium channels in sensory neurons (e.g., $\mathrm{Na}_{\mathrm{v}} 1.8$ and 1.9) an important role for TTX sensitive channels cannot be excluded. Intrathecal TTX has been reported to have mild effects upon acute and inflammatory nociceptive end points [146]. $\mathrm{Na}_{\mathrm{v}} 1.3$ and 1.7 produce TTX-sensitive sodium currents and have been shown to contribute to ectopic firing in injured neurons. As noted above, $\mathrm{Na}_{\mathrm{v}} 1.3$ expression increases with nerve injury. Intrathecal knockdown of these channels with antisense reduced their upregulation in nerve injury and reduced the behaviorally defined tactile allodynia [147-149]. The use of intrathecally-delivered siRNA and antisense targeting these structures clearly offers a direct approach to targeting these membrane proteins $[127,130,131]$. An alternate strategy for selective targeting has been the use of non-selective blockers that are restricted in terms of the cells to which they have access. The quaternary lidocaine molecule (QX314) cannot readily penetrate the cell. However, activating membrane channels such as the TRV1 channel has been reported to allow QX314 entry into the neurons and to block the $\mathrm{Na}_{\mathrm{v}}$ channel from the interior and result in a selective block of the TRPV1 expressing primary afferent [150]. Intrathecal QX316 has been reported to produce significant pain behavior after intrathecal delivery in rodent models and this may reflect upon its ability to concurrently activate the TRPV1 channel [151]. It should be noted that while this section considers the role of sodium channel blockage in reducing axon excitability, it has been shown that conditions leading to an enhanced expression of sodium channels often lead to a reduction in the expression of potassium channels which further contributes to membrane excitability [152]. Increasing potassium conductance with potassium channel agonists or increasing the expression of potassium channels can serve to move the membrane towards a hyperpolarized state and normalize (reduce) otherwise enhanced axon, DRG and terminal excitability, an action associated with an antihyperalgesic action $[153,154]$.

\section{Spinal Calcium Channel Blockers}

\section{Spinal Antagonists}

Ziconotide (Prialt), discovered in the venom of fishkilling marine snails [155], was demonstrated to be a potent antihyperpathic agent in rodents and humans after intrathecal delivery as a bolus or an infusion [156-159]. Ziconotide was observed to be a highly selective ligand blocking the N-type voltage-sensitive calcium channel (VSCC) [160].

\section{Mechanisms of Action}

VSCCs facilitate neurochemical cell signaling through mobilization of presynaptic vesicles for neurotransmitter release. The N-type calcium channel is most important for neurotransmission in sensory neurons. This calcium channel subtype is densely expressed in presynaptic nerve terminals in the spinal cord superficial dorsal horn and dorsal root ganglia. In the presence of nerve injury these channels are upregulated [161] and blocking these channels has shown to produce antinociceptive effects [162] that do not show tachyphylaxis (tolerance) [163].

\section{Drug Molecules}

Ziconotide, an $\omega$-conotoxin derived from the cone snail, is a calcium channel blocker that binds with high affinity and physically blocks the N-type calcium channel. It is a stable, water soluble, large 25 amino acid, polybasic peptide containing three disulfide bridges with a molecular weight of $2639 \mathrm{Da}$. Ziconotide is FDA approved for intrathecal use for chronic, severe pain.

\section{Adverse Events}

In animals, ziconotide produces dose-dependent body shaking and ataxia $[157,164,165]$. A narrow therapeutic index reflecting nonspinally mediated side effects such as dizziness, nausea and somnolence has limited the human clinical utility of ziconotide. Extensive large animal preclinical safety evaluations have emphasized the lack of tissue toxicity of this molecule at clinically useful concentrations [166].

\section{Future Directions for Spinal Calcium Channel Blockers}

i) Currently the only $\mathrm{N}$ type channel blocker approved as a therapeutic is Ziconotide. Considerable work has focused on the development of other conopeptides as well as small molecules [160, 167]. Alternatively, there is considerable interest in altering N-type VSCC function by impeding its membrane trafficking and such strategies have been shown to alter nociceptive processing [168]; ii) VSCCs are broadly divided into two types: high-voltage-activated (HVA) and low-voltage-activated (LVA) channels. HVA channels are further divided into L-, P/Q-, N- and R-type channels. LVA channel include the T-type channel. Each channel locates in a distinct area in the peripheral nerve and $\mathrm{CNS}$ and contributes in different ways to nociceptive transmission (see [169]). Spinal blockade of R- and T-type but not L and P/Q type VSCCs attenuated formalin-induced pain behavior [170-172]. In other work, intrathecal PQ-preferring toxins displayed efficacy in neuropathic pain models [173]. Intrathecal delivery of T-type calcium channel blockers 
(ethosuximide and mibefradil)produce analgesia in rodents $[171,174]$. iii) An alternate therapeutic target thought to involve regulation of VSCCs is the $\alpha_{2}$ delta calcium channel auxiliary subunit. This subunit is the binding site for gabapentinoid drugs in the dorsal horn. In preclinical models, gabapentin and pregabelin have been shown to have potent effect in a variety ofhyperalgesic pain [175-178] Preclinical results indicate adequate spinal $\mathrm{pK}$ with a very hydrophilic $\operatorname{cLogP}(-1.13)$. In a recent study, however, it was unexpectedly reported that intrathecal infusion of gabapentin failed to alter pain assessments in human patients suffering from a variety of neuropathic and non-neuropathic pain states [179].

\section{NMDA Ionophores}

\section{Spinal NMDA Antagonists}

A wide variety of NMDA ionophore antagonists given intrathecally have been reliably shown to have potent attenuating effects upon the hyperpathia resulting from a variety of tissue [99, 180] and nerve injury [181] facilitated pain states in animals and, though not approved, in humans [182].

\section{Mechanisms of Action}

The NMDA receptors are heteromeric protein complexes assembled from three families of NMDA receptor subunits (NR1, NR2 and NR3) each with multiple distinct subunits [181]. When activated it allows the influx of sodium, potassium and calcium. Glutamate, released from afferents and interneurons in response to high threshold noxious input from $\mathrm{C}$ fibers, binds target sites on the NMDA receptor. These receptors are densely expressed in spinal cord dorsal horn on the terminals of the primary afferent, on second order neurons as well as in non-neural cells such as astrocytes and oligodendroglia. Activation of the channel requires the presence of occupied binding sites on the ionophore for glycine and polyamines [183]. At resting membrane potentials a $\mathrm{Mg}++$ ion provides a block in the channel that effectively prevents calcium flux through the channel. In the face of repetitive activation, the membrane displays progressive depolarization, relieves the $\mathrm{Mg}++$ block and allows calcium flux [183], leading to a cascade initially described electrophysiologically, as wind-up [184]. Blocking NMDARs inhibits the wind-up phenomenon of spinal dorsal horn neurons [185, 186]. This increased excitability further results in activation of a variety of protein kinases (Mitogen activated kinases and PKA and PKC) which, respectively, increases protein synthesis, phosphorylates channel and enzymes that lower their thresholds for activation and enhances their ion permeability leading to hyperalgesic states [187-190].

\section{Drug Molecules}

Numerous NMDA antagonists have been employed for preclinical work showing the antihyperpathic effects of intrathecal NMDA antagonists [191-194]. These include channel blockers such as ketamine (cLogP: 3.1), MK-801 (cLogP: 2.7) and memantine $(\mathrm{cLogP} 2.0)$, and competitive antagonists such as 2 amino 5 phosphonovalorate ( $\log \mathrm{P}=-2.32$ ), glycine site blockers such as 7 Chlorothiokynurenic acid
(cLogP: 2.7). No NMDA antagonists have been approved for human neuraxial use.

\section{Adverse Events}

Single intrathecal injections of ketamine did not produce histological alterations in the dog [195] but resulted in spinal cell death in the neonatal rat [196]. After repeated intrathecal delivery in rabbits [197] or continuous infusion in dogs [198], Ketamine and a number of other NMDA channelblocking antagonists including MK-801, dextrorphan, dextromethorphan and memantine and the nonopiate agent D-methadone, and to a lesser degree the glutamate antagonist 2AP5,resulted in prominent spinal pathology reflecting parenchymal necrosis in dogs and/or sheep [198, 199]. These spinal effects, where examined, appear to be concentrationdependent and, with the exception of the neonatal model, the therapeutic ratio (e.g., therapeutic dose/minimum toxicity dose-concentration) has not been defined. It should be noted that a weakness of these studies is that there was no corresponding assessment of the efficacy of the intrathecal infusion was assessed relative to the dose required to produce pathology in these animals models (but see [196]).

\section{Future Directions for Spinal NMDA Antagonists}

i) Preclinical work and anecdotal clinical data clearly indicate the efficacy of spinal NMDA antagonism. However, in light of the controversy related to the intrathecal toxicity of NMDA antagonists (see above), characterization of the intrathecal therapeutic ratio for the NMDA antagonist is necessary to define the relative safety of these agents. While their ability to produce untoward histopathology is evident, it is not clear how close the toxicity is in the adult, continuously infused animal to the dose-producing beneficial consequences. ii) The NMDA ionophore is constituted of a variety of subunits. Ionophores constituted of different subunits have different binding profiles and are differentially distributed [200, 201]. One such subtype is the NR2B subunit. Specific antagonists such as Ifenprodil [202], Ro 256981 [202, 203] and Conantokin G [204] has antihyperpathic effects in models of spinal injury and facilitated processing. Other NMDA ionophore-associated targets for which ligands have been shown to produce analgesia include the glycine binding site and the polyamine binding site [201, 205]; iii) Magnesium sulphate is a noncompetitive antagonist of the $\mathrm{N}$ methyl-d-aspartate (NMDA) receptor and thus can modify nociceptive modulation [206-207]. Limited preclinical safety studies have been performed examine the effects of bolus delivery in several species. At least one preclinical paper has reported evidence of neurotoxicity after intrathecal delivery [208]. Chronic spinal exposures have not been examined. A variety of reports have noted activity in humans after intrathecal and epidural delivery [209]. iv) Agmatine is an endogenous neuromodulator present in the brain and spinal cord that has both NMDA receptor antagonist and nitric oxide synthase inhibitor activities. It has been reported to have antihyperalgesic properties after systemic and intrathecal delivery [210]. v) The primary focus of glutamate ionotrophic receptors has been on the NMDA. However, the AMPA receptor plays a prominent role in acute dorsal horn evoked excitation as a sodium selective ionophore [211]. 
Agents such as Tezampanil ( $L Y-293558, N G X-424)$ given spinally in preclinical studies has effect upon postoperative pain and spasticity $[212,213]$ and its action were associated with changes in motor function, a fact consistent with the prominent role of AMPA in motor neuron excitation. In humans oral dosing has indicated some effects upon afferent evoked hyperalgesia [214]. vi) The AMPA receptor is composed of GluR1-GluR4 subunits. In the face of injury, there is a change in subunit trafficking and ionophore composition such that the ionophore becomes calcium permeable. Intrathecal antagonists selective for the calcium permeable AMPA site, such as joro spider toxin, reduces the development of secondary mechanical allodynia evoked in tissue injury models [215-216].

\section{GABA-A}

\section{Spinal GABA-A Activation}

Preclinically, intrathecal GABA-A agonists such as muscimol or isoguavacine have been reported to display efficacy in neuropathic pain models [217-221]. Intrathecal benzodiazepines and neurosteroids have been shown precliincally in rodent models to attenuate tissue and nerve injury hyperpathic states [218, 222-226]. In dogs, intrathecal benzodiazepines have been shown to depress nociceptive reflexes [227]. In humans, bolus intrathecal Midazolam was reported to display efficacy after bolus deliveryin postoperative, low back and labor pain [228-231].

\section{Mechanisms of Action}

The GABA-A receptor is a GABA gated chloride ionophore composed of five subunits, each with four transmembrane spanning domains. With multiple subunits, not surprisingly, several different pharmacological and functional phenotypes of the receptor have been identified [232]. GABA binds at an $\alpha$ and a $\beta$ subunit [233] to activate the $\mathrm{Cl}$ conductance. Importantly, numerous agents interact with specific sites on the GABA-A ionophore to serve as positive allosteric modulators. Thus, benzodiazepines (e.g., midazolam, diazepam) bind to specific populations of GABA-A ionophores that possess both an $\alpha$ and a $\gamma$ subunit. This binding forces a conformation where GABA displays a higher affinity increasing the frequency of opening of the ion channel [234]. Similarly, several neurosteroids such as allopregnanolone will bind to the GABA-A ionophore and force conformational changes enhancing GABA effects $[235,236]$. Immunohistochemical studies have shown dense staining in spinal Rexed laminae for several alpha, beta and gamma subunits likely corresponding to primary afferents $[237,238]$ presumably localized on primary afferent terminals. Electrophysiological studies have indeed shown GABA-A receptors to be present on both large and small afferents [239] and such studies have emphasized the potent regulation by benzodiazepines of the excitability of small, nociceptive, primary afferents through their associated GABA-A receptors [240]. There is not enough space here to review the differential distribution of functionally distinct GABA-A receptor phenotypes, but electrophysiological and knockout studies have shown considerable phenotype diversity in the neuraxis [241, 242].

\section{Drug Molecules}

As noted above, the common agonists employed in pharmacological studies of the GABA-A receptor are muscimol $(\mathrm{c} \log \mathrm{P}=-0.7)$. Agents serving as allosteric modulators include benzodiazepines (midazolam; $\operatorname{cLogP}=3.16$ ) and neurosteroids (allopregnanolone; $\operatorname{cLog} \mathrm{P}=3.7$ ).

\section{Adverse Events}

Activation of nonspinal GABA-A ionophores has prominent sedative, anxiolytic and amnestic effects. At the spinal level enhanced GABA-Aactivity has been shown to have effects upon motor function [243]. The use of intrathecal midazolam in man has been reported as noted above. However, there has been concern about the potential for spinal toxicity [243, 244]. While several systematic assessments of toxicity have shown distinct deleterious reactions $[245,246]$, others have failed to observed toxicity [56]. The origin of the preclinical toxicity is not known, but the acidic $\mathrm{pH}$ required by the formulation of midazolam may be a contributing issue (see for review [244]. In our opinion, concern over its potential for toxicity remains. Barbiturates act through the GABA A ionophore, but their spinal action may be associated with a cauda equine syndrome. Such has been the case after inadvertent intrathecal injection of sodium thiopental [247].

\section{Future Directions for Spinal GABA-A Agonists}

As noted above, a high degree of heterogeneity of the GABA-A receptor structure/subtype has been observed, which raises the possibility of defining specific structures targeting these subtypes [242, 248-250]. Activation of spinal GABA-A ionophores either directly through agonist activation or by positive allosteric modulators has significant preclinical support for further development as reviewed above with benzodiazepines and neurosteroids. Interestingly agent such as Etifoxine may act by stimulating allopregnanolone synthesis in the spinal cord [251]. Current work has shown that subtype specificity may be achieved and that they may have different effects upon neuronal inhibition in different systems [252].

\section{GABA-B Receptors}

\section{Spinal GABA-B Agonists}

Baclofen, the clinically approved GABA-B agonist, has potent stereospecific suppressive effects upon motor tone [253] and is widely used clinically to regulate motor tone in the case of spasticity [254-256]; but it has also been implicated in having suppressive effects upon nociceptive processing after intrathecal delivery in preclinical models of facilitated processing [217] and hyperpathia in mono and polyneuropathies and spinal injury [220-221, 257-259] and in humans $[260,261]$.

\section{Mechanisms of Action}

The GABA-B receptor is a metabotrophic receptor coupled to intracellular signaling through Gi and Go proteins that, when stimulated, activate $\mathrm{K}+$ and inhibit $\mathrm{Ca} 2+$ channels via the $\beta \gamma$ complex, with the $\alpha$ subunit regulating adenylate 
cyclase [262]. They are dense in laminae I and II in the dorsal horn on small afferent terminals and on $2^{\text {nd }}$ order neurons [263]. DRG neurons of various diameters also express GABA-B immunoreactivity. At the electron microscopic level, the immunoreactivity is present on myelinated and unmyelinated fibers and on the dendrites of dorsal horn neurons. Electrophysiological studies show that GABA-B agonists initiate hyperpolarization through an increase in $\mathrm{K}$ conductance through $\mathrm{G}$ protein coupling and attenuation of evoked primary afferent transmitter release through block of opening of voltage gated $\mathrm{Ca}$ channels. GABA-B receptors are present on motor neurons and serve to reduce their excitability leading to flaccidity at doses that are similar to those yielding antinociception.

\section{Drug Molecules}

The common GABA-B agonist is baclofen $(\mathrm{cLog} P=1.3)$, which exerts its effects in a stereospecific fashion [253, 264]. GABA-B selective antagonists, such as saclofen [265], block the effects of these agents.

\section{Adverse Events}

Intrathecal baclofen produces a prominent dosedependent motor weakness in animal models and humans [253]. In humans, this effect has a particular therapeutic benefit in managing clinically relevant spasticity (see [256]). Intrathecal baclofen has undergone one published systematic toxicology evaluation in dogs involving a 28-day continuous infusion without evidence of toxicity [55, 266]. Intrathecal baclofen has been reported to result in intrathecal spaceoccupying masses, but this has proven to be controversial [267, 268].

\section{Future Directions for $G A B A-B$ Receptor Targeting}

Other GABA-B agonists have been identified and include agents such asCGP35024 and the more potent CGP 44532, which were reported to induce antinociceptive responses at doses below those that cause sedation [257, 269]. It has become clear that regulation of GABA-B activity is associated with a role for positive allosteric modulators to potentially reduce unwanted drug effects. These agents interact with discrete domains of the GABA-B receptor stabilizing it in the active state involved in G-protein coupling. Such agents have been found to modulate the GABA-B receptor analgesic activity [270].

\section{Spinal Cholinesterase Inhibitors \\ Spinal Cholinesterase Inhibitors}

Neostigmine is a cholinesterase inhibitor that yields antinociceptive effects in a variety of preclinical models [106, 271-275] in several species such as rodents and sheep [276]. Bolus intrathecal delivery of neostigmine has been reported in humans to have significant effects upon postoperative pain [277-279].

\section{Mechanisms}

Intrathecal cholinesterase inhibitors are considered to increase the local extracellular levels of acetylcholine. Spinal delivery of a variety of cholinergic antagonists has indicated the importance of muscarinic receptors and in particular several $M$ subtypes in mediating these antinociceptive actions [280]. These findings are consistent with the antinociceptive effects of intrathecal muscarinic agonists [281]. Spinal muscarinic receptors in the spinal cord are strongly expressed in the superficial dorsal horn [282].There are five subtypes (M1-5) [283, 284] divided into two broad groups: $\mathrm{M} 1 / \mathrm{M} 3 / \mathrm{M} 5$ coupled to $\mathrm{G}_{\mathrm{q} / 11}$ proteins, activating phospholipase C - IP3-diacylglycerol (DAG) cascade yielding increased $\mathrm{Ca}^{2+}$ and activation of protein kinase $\mathrm{C}$ and mitogen-activated protein kinases. M2 and M4 receptors (M2-class) coupling to $\mathrm{G}_{\mathrm{i} / \mathrm{o}}$ proteins and inhibiting opening of voltage-gated calcium channels [284]. M1/3/5 receptors induce membrane depolarization by enhancing cation currents and inhibiting potassium channels [285, 286], while M2 and M4 channels activate potassium channels and inhibit some voltage-gated $\mathrm{Ca}$ channels (especially $\mathrm{Ca}_{\mathrm{v} 2.2}$ ), leading to hyperpolarization and block of transmitter release [287]. $\mathrm{M}_{2}$ and $\mathrm{M}_{4}$ knockout animals show a robust attenuation of the analgesic effects produced by muscarinic agonists [165, 288, 289] Interestingly, stimulation of $\mathrm{M}_{2}$ and $\mathrm{M}_{4}$ receptors inhibit spinal glycinergic function which might lead to a paradoxical hyperpathia, whereas stimulation of the M3 activation potentiates synaptic glycine release [290]. The events underlying the effects upon spinal nociceptive processing have been proposed to reflect several mechanisms.1) effect of muscarinic receptor subtypes in reducing afferent terminal excitability (reducing glutamate release) [289]; and, 2) activation of muscarinic receptors on glycinergic and GABAergic interneurons enhancing dorsal horn inhibitory amino acid release through muscarinic subtypes, such as the M2 and M4 receptors [290, 291].

\section{Adverse Events}

The safety of intrathecal neostigmine has been examined systematically in rats after multiple bolus deliveries and after chronic infusion in the $\operatorname{dog}$ [292] and no apparent tissue toxicity was noted. In humans, intrathecal neostigmine has been shown to provoke nausea and vomiting [277].

\section{Future Directions}

Considerable work has focused on the development of novel muscarinic agonists and cholinesterase inhibitors [293]. As noted above, there is considerable evidence that subtypes of muscarinic receptors may be involved in the spinal antinociceptive actions and anticholinesterase targeted agents.

\section{Adenosine}

\section{Intrathecal Adenosine}

Delivery of adenosine and associated ligands can have potent antihyperalgesic effects in models of acute nociceptive processing [294], neuropathy [294-298] and inflammatory pain [299]. In humans, intrathecal adenosine has been shown to reduce allodynia in experimental pain models [300, 301] and in patients with neuropathic pain [302,303]. Negative results with intrathecal adenosine have also been reported [304]. 


\section{Mechanisms}

Adenosine can activate four G-protein-coupled receptors: $A_{1}, A_{2 A}, A_{2 B}, A_{3}$ [305]. $A_{1}$ receptors are expressed on smallto-medium-diameter neurons of the DRG and on dorsal horn neurons [306-309] and serve to inhibit synaptic transmission through presynaptic inhibition of neurotransmitter release and on postsynaptic inhibition of excitatory transmission [309, 310].

\section{Adverse Events}

In preclinical studies, $A_{1}$, agonists and $A_{2 A}$ antagonists reversibly depressed the volume-evoked micturition reflex $[311,312]$ and produced motor weakness. An unexpected observation was that chronic exposure of spinal systems to $\mathrm{A}_{1}$ agonists led to a hyperalgesic state [313]. The safety of intrathecal adenosine has been examined systematically in rats after multiple bolus deliveries and after chronic infusion in the $\operatorname{dog}[300,314]$ with no adverse signs or histopathology. Studies with intrathecal delivery of the $\mathrm{A}_{1}$ agonistR-phenylisopropyl adenosine (R-PIA) also failed to show histopathology [315].

\section{Future Directions}

It has been reported that $\mathrm{A}_{2 \mathrm{~A}}$ receptor agonists may produce a long-term reversal of allodynia in mononeuropathies [316]. It has been proposed that the mechanisms of this long-term effect may reflect the effects of $\mathrm{A}_{2 \mathrm{~A}}$ agonists as potential glial inhibitors. The complexity of this possible drug effect is also reflected by the observation that $\mathrm{A}_{2 \mathrm{~A}}$ receptors may serve to stimulate glutamate release and that $\mathrm{A}_{2 \mathrm{~A}}$ antagonists may have protective effects by reducing that excitatory effect [317].

\section{Cyclooxygenase Inhibitors}

\section{Cyclooxygenase Inhibitors}

Considerable work has shown that in the face of persistent small afferent input there is an increase in the release of cyclooxygenase products such as PGE2 [318-320]. This increase results from activity in constitutively expressedCOX-2 in spinal dorsal horn neurons and glia [321]. The role of these PGs in the development of a sensitized dorsal horn state of processing is mediated by several mechanisms including enhanced opening of voltagegated calcium channels [322] and the loss of intrinsic inhibition by an inhibitory effect upon dorsal horn glycine receptor function [323]. Intrathecal delivery of COX-1/2 or COX-2 selective inhibitors has been shown to have antihyperalgesic effects in a variety of models producing central sensitization [318, 324-326]. Spinal COX-1 inhibition has attenuating effects upon postoperative pain [327] and Ketorolac is a mixed COX-1/2 inhibitor. Preclinical work has shown no evidence of toxicity in repeated bolus injections in the rat and continuous intrathecal infusion in the $\operatorname{dog}[328,329]$ and was well tolerated in humans [330]. In human studies, intrathecal ketorolac delivered as a bolus had modest effects in human experimental pain models [331], enhanced morphine analgesia after total knee replacement [332], but had no effects on postoperative pain [333] or hip arthroplasty [334].

\section{Other Potential Pharmacological Spinal Targets}

In this section, we will briefly consider the role of several pharmacological targets that have been shown to play a role in spinal nociceptive processing. It should be stressed that virtually all of the mechanistic studies defining pain processing have shown the importance of spinal systems. Accordingly, future pharmaceutical targets may likely arise from one or more of systems that have been shown to have actions on the behaviorally defined pain end point after intrathecal delivery in one of more preclinical models (see [10-11]). Several of these will be summarized below. Importantly, most of these agents and their associated targets have not undergone any systematic assessments of toxicity and may carry with them unexpected/off-target membrane effects.

\section{Metabotrophic Glutamate Receptors (mGluR)}

Eight mGluRs (mGluR1-8) have been identified and these are divided into three groups [335]: Group I (mGluR1 and mGluR5) stimulates phospholipase C (PLC); Group II (mGluR2 and mGluR3) and Group III (mGluR4 - mGluR8) inhibit adenylate cyclase $[335,336]$. In the brain and spinal cord, nGluRs have been identified on primary afferents, neurons and glia $[337,338]$. Group I is localized postsynaptically, whereas Group II and Group III are present largely on the presynaptic terminal [339]. Activation of Group I mGluRs have been implicated in the processes of central sensitization and persistent nociception, whereas activation of Group II mGluRs has been shown to suppress facilitated states [340]. Accordingly, antagonists of Group I mGluRs and agonists of Groups II and III mGluRs have shown analgesic activity in neuropathic or inflammatory pain states [341-348] and accordingly represent a promising target for the development of future spinally-targeted agents $[349,350]$.

\section{Toll Receptors}

Toll-like receptors (TLRs) are a family of pattern recognition receptors that recognize a variety of injuryassociated molecular structures. They are located on neuronal and non-neuronal cells in the spinal cord and signal through downstream pathways that often lead to anelaboration of a variety of proalgesic/inflammatory cytokines(DRG) $[351,352]$. Intrathecal delivery of TLR4 antagonists has been shown to have ameliorating effects upon inflammatory and neuropathic pain states [353] and has been implicated in the phenomena of opiate-induced hyperalgesia [354]. Novel structures for blocking TLR activation through an interaction with the TLR4 ligand or targeting downstream signaling have been of therapeutic interest [355-357].

\section{Cannabinoids}

Cannabinoid receptors (CB1r and $\mathrm{CB} 2 \mathrm{r}$ ) are 7 transmembrane, G-protein- coupled receptors that negatively couple through Gi/o proteins [358]. Spinally, CB1 receptors are expressed in neurons while $\mathrm{CB} 2$ receptors are expressed on microglia, where the $\mathrm{CB} 1$ agonists reduce excitatory transmitter release and $\mathrm{CB} 2$ receptors attenuate microglial activation $[359,360]$. Intrathecal delivery of both $\mathrm{CB} 1$ and $\mathrm{CB} 2$ preferring ligands reduced facilitated states such as the 
formalin model, hyperpathia in neuropathy models and in tumor bone pain in rodents [361-363]. As many of these ligands have very high $\mathrm{cLogPs}$, appropriate formulation in spinally compatible vehicles is an important consideration in their development for spinal use.

\section{Purine Agonist/Antagonists}

Adenosine triphosphate is widely released in the nervous system [364] and has been shown to interact with the P2 receptor family, which is divided into $\mathrm{P} 2 \mathrm{X}$ ligand-gated ionotropic receptors (further divided into 7 subtypes) and $\mathrm{P} 2 \mathrm{Y} \backslash \mathrm{G}$-protein-coupled receptors divided into 8 subtypes). The P2Y receptors may couple through either $G_{q} / G_{11}$ to activate the phospholipase $\mathrm{C} /$ inositol triphosphate $\left(\mathrm{InsP}_{3}\right)$ endoplasmic reticulum $\mathrm{Ca}^{2+}$-release pathway (the $\mathrm{P}_{2} \mathrm{Y}_{1}$, $\mathrm{P} 2 \mathrm{Y}_{2}, \mathrm{P}_{2} \mathrm{Y}_{4}, \mathrm{P} 2 \mathrm{Y}_{6}$, and $\mathrm{P} 2 \mathrm{Y}_{11}$ receptors) or through to $\mathrm{G}_{\mathrm{i} / \mathrm{o}}$, which inhibits adenylyl cyclase and serves to modulate ion channel function [365]. Both P2X and P2Y receptors are widely distributed in spinal dorsal root ganglia and in spinal neurons and glia [366]. A large persuasive literature has implicated these receptors as primary activators of glia, particularly microglia, leading to the spinal release of a plethora of proinflammatory proteins and cytokines relevant to initiating facilitated pain states [367-371]. Intrathecal delivery of a variety of $\mathrm{P} 2 \mathrm{X}$ and $\mathrm{P} 2 \mathrm{Y}$ inhibitors results in a temporary reversal of hyperpathia after nerve injury [372375]. Studies with a variety of approaches have strongly implicated the P2X4 subtype in spinal facilitation initiated by tissue and nerve injury [376]. Intrathecal administration of a P2X4R antisense oligodeoxynucleotide prevented the increase in $\mathrm{P} 2 \mathrm{X} 4 \mathrm{R}$ protein expression and suppressed the development of mechanical allodynia [372].

\section{Anti-Inflammatory Cytokines (IL-10)}

Activation of a variety of glial signaling cascades will lead to the release of a variety of cytokines including activation of $\mathrm{NF}-\kappa \mathrm{B}$ and results in the production of proinflammatory mediators such as TNF, IL-6, and IL-1 $\beta$ that activate pro-algesic cascades [377]. Conversely, these cascades can lead to the release of so-called anti-inflammatory products that may bind the soluble product (IL-1 ra) and cytokines such as, IL-4, IL-6, IL-10, IL-11, IL-13, TGF- $\beta$, and various soluble cytokine receptors [378], which can regulate the inflammatory cascade [379]. As an example, intrathecal delivery of IL-10 has been shown in animal models to have therapeutic efficacy in a variety of pain models [380].

\section{Future Targeting}

An exciting component of pain modulation has been the implementation of several novel approaches to modify the function of systems that process nociceptive information. A brief note on these approaches will be given below.

\section{Targeted Toxins}

This approach takes advantage of toxin delivery to specific cell systems. Several examples can be considered.

\section{$\underline{T R P V 1 \text { Receptors }}$}

These TRPV1 channels are present on the terminals of small high threshold primary afferents and when activated by ligands such as capsaicin [381] and analogues [382] will yield activation, desensitization and loss of terminals expressing the channel after spinal delivery [383]. Intrathecal resiniferatoxin, a potent TRPV1 agonist, has been shown to have a potent antihyperalgesic effect in canine persistent pain models [384] and is currently in human clinical trials (http://clinicaltrials.gov/show/NCT00804154). A further modality for targeting TRPV1- bearing neurons takes advantage of the fact that when activated TRPV1 forms a pore that is able to pass large charged molecules. Protonated local anesthetics (e.g., QX314), which cannot normally enter the axon, can pass through TRPV1 channels that have been opened by TRPV1 agonists such as capsaicin and produce a selective block of sodium channel function in the TRPV1 (+) afferent axon [385].

\section{Toxins Coupled to Agonists for G-Protein-Coupled $\underline{\text { Receptors }}$}

G-protein-coupled receptors when occupied by their agonists will undergo internalization [386]. Composite molecules composed of the ligand and a toxin will bind to the respective GPCR. Such binding leads to an internalization of the agonists and the coupled toxin into the cell expressing the particular receptors [387]. Such GPCRs thus far intensely studied include those for the neurokinin 1 for $\mathrm{sP}$. These receptors are present on cells within the spinal pain pathway. The spinal neurokinin 1 receptor is located on postsynaptic second order neurons [388]. The majority of work at present has focused on the NK1-r. However, other G-protein receptors that are likely ligands are the mu receptors. As reviewed above, mu opiate receptors located in the spinal cord are primarily located in Laminae I and II on the nerve terminals of primary afferent C-fibers and interneurons in Lamina II. Agonist binding to these receptors leads to their internalization [19].

i) Saporin, a protein derived from the plant Saponaria officinalis, has been coupled to a variety of ligands including dermorphin, a ligand for the mu opiate receptor, and $\mathrm{sP}$, the ligand for the neurokinin 1 receptor. The internalized saporin is cleaved in endosomes within the cell and serves to block ribosylation thereby preventing protein synthesis and leading to death of the targeted cells. Intrathecal sP-saporin has been shown to lead to a robust change in a variety of pain states in several species including the rodent [389] and dog [261]. Large animal safety studies have shown target engagement after intrathecal delivery showing local knockdown of spinal NK1-r protein and message [390]. Importantly, at high concentrations motor dysfunction was observed that reflected upon the presence of NK1-r in motor neurons in the dog. Intrathecal sP-Saporin is currently in human clinical trials (http://clinicaltrials.gov/show/NCT02036281).

ii) Botulinum toxin. Botulinum toxin is constructed of a heavy chain (HC) and a light chain (LC). The HC enables the uptake of the complex into the cell. Once in the cell, the complex is cleaved freeing the LC, which is the active enzyme cleaving SNARES [391]. SNAREs play an important role in mobilizing vesicles for transmitter release and in enabling movement of certain proteins to the membrane, such as the GLUA1 AMPA receptor subunits [392]. By cleaving SNAREs, transmitter release is blocked 
and intracellular trafficking may be diminished. Intrathecal BoNTs have been shown to produce antihyperalgesic effects in a number of preclinical models of inflammatory and neuropathic hyperpathia [393-396]. The BoNT uptake is considered to be ubiquitous and the potent effects upon transmitter release may include inhibitory interneurons and motor neurons [397, 398]. A single human experience has emphasized the potential of producing an enhanced pain state, perhaps through block of inhibitory amino acid release [399]. An approach to achieving specificity has employed the GPCR coupling motif described above. Here sP coupled to the LC may be delivered IT and the coupled molecule uptake is restricted to cells that express the NK1 receptor [400]. Such an approach is reversible and may find utility in long-lasting but non-terminal pathophysiological pain states.

\section{Gene-Based Approaches}

Targeting specific proteins that play a role in nociceptive processing has been accomplished with several methodologies including intrathecally-delivered antisense and viral and nonviral transfection [401-403].

i) Intrathecal antisense has been employed to reduce expression of a variety of proalgesic mediators, including growth factor cellular matrix proteins (thrombospondin) [404] and receptors relevant to nociceptive processing, including the NK1 receptor for substance $\mathrm{P}$ [405], purines [372]; GFR $\alpha 1$, receptor for GDNF [406], NMDA receptors [407]; glutamate metabotrophic receptors [408-410], P2X3 [411, 412], TrpV1 receptors [413], TrpV1 receptors [413], CCR2 (canonical receptor for MCP-1) [414], synaptic scaffolding proteins [415], a variety of kinases such as P38 MAPK [416, 417], phospholipases [418], and a variety of channels including sodium $\left(\mathrm{Na}_{\mathrm{v}} 1.8\right.$ : $[419,420]$ and calcium channels (T-type: [421, 422]). Inactivating transcription factors by employing an oligonucleotide decoy protein represents an alternate approach to prevent activation otherwise initiated by a pain state [423].

ii) Transfection by intrathecal delivery of viral vectors encoding a given protein or the use of nonviral methods such as nanoparticles or permeabilizing systems [403] can enhance the targeted protein expression in vivo. Several examples may be noted. i) Dorsal root ganglion neurons virally transduced with a vector coding for glutamic acid decarboxylase (QHGAD67) increase the release of spinal GABA to produce an analgesic effect [424-425]. ii) Animals displayed increased expression of endomorphin-2, an opioid peptide [426], or the preprohormone for enkephalin [427] or $\beta$ endorphin [428] after intrathecal vector transfection elevated thresholds. iii) The use of intrathecal viral vectors or plasmid delivery to increase appropriate antihyperalgesic targets has been shown to have utility. Thus, increased spinal expression of IL-10 (anti-inflammatory cytokine)or plasmid delivery was anti-hyperalgesic [424, 429-431]. Increasing MAPK (Mitogen activated protein kinase) phosphatase-1 reduces activation of $\mathrm{P} 38$ MAPKs and this resulted in reduced nerve injury-evoked increases in inflammatory cytokines and chemokines and hyperalgesia [432]. Increased expression of the $\mathrm{Ca}^{2+}$ channel-binding domain 3 (CBD3) peptide blocks function of Ntype calcium channels and block nerve injury-induced hyperpathia [433]. Increased expression of the potassium channel Kv1.2 reduced nerve injuryinduced hyperpathia [434]. Transfecting small interfering RNAs can be used to reduce $\mathrm{Na}_{\mathrm{v}} 1.7 \mathrm{RNA}$ and protein in DRG and reduce hyperpathia in diabetic rats [435]. An important issue is the ability of various viral vectors to transefect dorsal root ganglion cells vs.spinal parencyhma. After intrathecal delivery, DRG neurons are readily transfected wheras the transfection of spinal neurons appears restricted at best [436]. Issues related to the ability of viral particles to move into the parechnyma have been consideredas well as the use of direct intraparenchymal injections [437]. Here the potential role of the pia mater in establishing such a barrier to particulates and larger molecules in the CSF has been noted in humans and dogs [438-440]. Techniques to increasethat movement have been proposed,including the use of hypertonic solutions [441].

\section{Future Issues of Intrathecal Delivery}

\section{Intrathecal Drug Distribution}

The effect of intrathecal local anesthetics upon sensory input reflects their interaction with sodium channels on the sensory root (or upon superficial long tracts). Other agents exerting their action at specific receptors or certain channels, such as those for the mu opiate, GABA-B agonist, the Ntype calcium channel, or agents such as substance $\mathrm{P}$ saporin targeting NK1 receptor-bearing cell bodies, must reach the appropriate sites to regulate the input from the root innervating a given dermatome. This required targeting poses several issues. 1) As reviewed above, these targeted sites lie largely on the terminal of the primary afferent and/or upon cells postsynaptic to the afferent input. Accordingly, at the least, we can appreciate that if these agents remain in the intrathecal sac, they, unlike local anesthetics, have an action upon coupled receptors that are present on the terminals of the axon or postsynaptic neurons. 2) Pain arising from a specific dermatome, myotome or sclerotome reflects afferent input from defined dorsal root ganglion cells. Importantly, after entry into the dorsal horn, the sensory afferent axon sends collaterals rostrally and caudally as far as 4-6 spinal segments [442, 443]. Thus, current thinking is that the input arising from any given dermatome represents an excitatory drive that is mediated in the dorsal horn not just at the spinal segment of entry, but also at levels up to several spinal segments in distance.3) Terminals of small sensory axons lie within the parenchyma (substantia gelatinosa) at depths ranging from $10-20 \mu$ (mouse and rat) to $200-300 \mathrm{mu}$ in the dog and $500 \mathrm{mu}$ in humans. Intrathecal (superficially applied) agents must diffuse into the parenchyma to reach these target sites. As diffusion from the surface to the presumed site of action is a time-dependent process that is proportional to distance, it is interesting to note that all things being equal for a given drug such as morphine, the time of onset is fastest in the mouse (2-3min) [444] and proportionally more delayed in larger animals (30 $\mathrm{min}$ in cat and dog) [445-447] to $>1 \mathrm{hr}$ in humans [448, 449]. Importantly, several variables define the ability of a drug to diffuse into tissue. Further, movement through lipid rich tissues is delayed for agents with $\operatorname{low} \log \mathrm{P}$ than for those with higher values. Thus, recording from deep dorsal horn (Lamina V) neurons in cat spinal dorsal horn, it was 
demonstrated that time to onset of suppression of cell activity was greatest from morphine and least for fentanyl $[450,451]$, a finding that corresponds to the behavioral time course effects of these agents in preclinical models [446, 447] and clinical experience [452]. A second variable reflects on the pathways for extracellular drug movement, referred to as tortuosity and based on diffusional studies. Large molecules typically display a more restricted movement than small molecules [453, 454].

Accordingly, it is believed that for these membranetargeted agents to produce a change in spinal nociceptive processing generated by a peripheral stimulus or spasticity, the intrathecally infused drug must move rostrally and caudally a distance of several segments and must then diffuse into the parenchyma to reach the membrane targets. Modeling of the CSF space has emphasized that spinal CSF does not undergo major flow $[455,456]$ and, thus, intrathecal agents delivered at a low rate, such as $10-20 \mu \mathrm{L} / \mathrm{hr}$ (as required by implanted pumps of limited reservoir volumes), undergo limited redistribution. This limited redistribution of low volume infusions has been emphasized in large animal models [38, 457-459] and to some degree inhumans [460].

\section{Drug Dosing}

A consequence of the intrinsically poor intrathecal redistribution of low volume injectates is the need to increase drug concentration to drive rostrocaudal movement. This use of high concentrations in human pumps has led to local toxicity. For opiates, the manifestation of this toxicity is the intrathecal granuloma [37, 116, 461-463]. Our group showed that the primary determinant for intrathecal opiate granulomas is the local concentration to which the tissue adjacent to the catheter tip is exposed [49, 51, 52]. Even baclofen, which has no strong evidence of granuloma formation in humans, may have limitations in that regard if concentrations higher than the currently available formulation $(2 \mathrm{mg} / \mathrm{mL})$ is employed ([464] but see [267]).

\section{Formulation}

An important issue characteristic for neuraxial delivery are the formulation requirements. Typically, neuraxial formulations are water-based products with a $\mathrm{pH}$ between 5-7 and osmolarity in the range of $300 \mathrm{mOsM}$ with minimal adjuvants (e.g., surfactants, antioxidants or antimicrobial constituents) (see: $[465,466])$. Few are generally regarded as safe vehicles. Surfactant/detergents (Tween, polyethylene glycol) or common solubilizing agents such as dimethylformamide or dimethylsulfoxide cannot be routinely considered as "safe" and evaluation of the safety of a spinal therapeutic employing such products must consider the potential direct tissue effects of the formulation at the specific concentrations being employed. It should also be appreciated that DMSO and other solvents can interact and solubilize various plastic-based hardware (e.g. catheters, syringes, tubing and plastics) used to administer the drug. The family of cyclodextrins has been widely employed preclinically for producing increased solubility and altered distribution of otherwise water insoluble agents [467-470]. Other formulation strategies, including liposome, microsphere and nanoparticle compounds, to enhance the duration of action and reduce peak concentrations of intrathecally-delivered agents have been proposed to permit single long-lasting drug delivery paradigms. Such systems have been described in ex vivo and in vivo work for baclofen [471, 472] (see [466] for review).

\section{Infusate Delivery Profile}

Enhancement of redistribution may minimize the risk of local intrathecal drug concentration-based toxicity. Strategies for enhancing redistribution and, accordingly, reducing the concentration at the catheter tip can been proposed. A solution to this issue by changing delivery of the total daily infused to multiple bolus dosing may enhance the efficacy and reduce the potential toxicity associated with intrathecal therapeutics. In previous work in the dog, continuous delivery of a given dose of morphine at a high concentration yielded granulomas. Continuous infusion of the same dose at a lower concentration did not result in a granuloma [51]. Daily bolus delivery of the same total dose of morphine had no effect [49, 447]. Other strategies that may possess at least theoretical interest is the use of repetitive microboluses instead of a truly continuous infusion and the use of multiport small orifice catheters that would evenly distribute injectate over the length of the catheter rather than from a single port at the catheter tip.

\section{Device Compatibility}

Implantable pumps require appropriate solution stability for the 4-6 weeks the pump is delivering. Stability of the solutions at body temperature and in the pump reservoir must be defined in the course of drug development. Further, formulations for continuous infusion require delivery by existing pump systems. High concentration solutions, extreme $\mathrm{pH}($ e.g., $<3)$ and formulations or drug combinations may exert effects upon pumping mechanisms. Each manufacturer may have compatibility protocols that require consideration for drugs to be delivered by such devices and literature exists for some agents and agent combinations (see, for example: $[473,474]$. Given the different mechanics of each pump (e.g., valved vs. peristaltic), compatibility in one pumping system dose not guarantee compatibility in another.

\section{Preclinical Assessments in Spinal Analgesic Drug Development}

The rodent models have been useful in defining the pharmacology of spinal nociceptive processing. As noted above, however, the use of neuraxial drug delivery poses issues related to scaling of the volumes and kinetics of the intrathecal space. The issue of whether an intrathecal molecule can make its way to the target site in the parenchyma of humans is not readily defined in the much smaller rodent cords. This raises the need to define effects upon behavior and target engagement in a large spinal cord. Further, the FDA requirements for a drug progressing to approval mandates safety to be demonstrated in a large animal preclinical model in addition to small animal (rodent) models. Particularly with regard to pharmacokinetic profiles, large animal models such as dogs, sheep, and primates offer similar metabolic functions [458, 475]. Experimental 
threshold models have been described for these species (see, for example, in dog [476-478] and in sheep [479, 480]. Such models, while useful, may not capture the complexities of the inflammatory/nerve injury pain states. Models of experimental injury such as joint injury in models of osteoarthritis are well described [481-485]. Of particular interest has been the growing implementation of clinical studies in companion animals and sheep suffering from natural pathologic processes accompanied by a pain condition. Such conditions in dogs include fore and hind limb osteosarcoma and osteoarthritis [486] and osteosarcoma [487]. Numerous scoring systems and scales are available for assessment of pain in animals, which range from simple descriptive scales, visual analogue scales, subjective verbal scales, numeric rating scale, and composite pain scales. Owner-completed questionnaires have been validated to assess the severity and impact of chronic pain syndromes in dogs with bone cancer and osteoarthritis [488]. Such inventories have been shown to be useful in defining the efficacy of a variety of spinal and [261, 384] systemic [489] therapies (see [490]. Strengths of such tools include its incorporation of animal behavior over a period of time as opposed to assessment once under the influence of an abnormal environment. Appropriate study design is essential in preclinical therapeutic assessment to ensure studies are carried out in a humane fashion with the effort to minimize the severity and duration of pain to that which is necessary for the information sought. Appropriate rescue therapeutics are incorporated into the study design as in human clinical trials to provide pre-emptive analgesia when at all possible, analgesia once the study endpoint is met or to provide rescue analgesia if pain is beyond the acceptable severity as determined by the study guidelines when pain is sustained in a study.

\section{Intrathecal Drug Safety Evaluation}

A final issue to consider in developing a spinal agent is the need for specific preclinical safety evaluations employing this route of delivery. Issues of such safety evaluations have been extensively discussed [243, 244, 462, 491]. Several specific guidelines will be outlined here.

i) At a minimum, drugs for neuraxial delivery must undergo preclinical safety assessments for the appropriate route (epidural/intrathecal) with the delivery motif proposed (e.g., bolus vs. continuous infusion) in functionally relevant large animal models (dog, sheep, primate), which have been shown to display drug responses in previous work. The use of large animals vs. small animals (e.g., rodent) reflects upon the issue of scaling of intrathecal volumes and kinetics across species particularly at the extremes.

ii) Study design must incorporate drug concentrations that meet or exceed those to be developed for human use and employ the respective formulation proposed for approval. Where feasible, the drug dosing should be shown to have appropriate target engagement (e.g., behavioral endpoints, CSF concentrations, and knock-out of target marker (e.g., receptor or enzyme protein). The development of such data is important not only because it demonstrates confirmatory effects in another species, it has the practical benefit of being able to show the safety data studies to be constructed so as to define safety as multiples of a therapeutically effective dose in a large spinal cord (see, for example [390]).

iii) In the development of chronically delivered agents, the minimum length of exposure profiles should be 1-3 months to ensure that long-term safety is demonstrated.

iv) Systemic safety must also be demonstrated for drugs or compounds administered spinally. Neuraxially delivered drugs undergo local distribution into the CSF. Flow patterns are largely influenced by respiratory and cardiovascular cycles (respirations and pulsations, respectively) with drug uptake into spinal cord tissue or into the meninges ultimately occurring. Elimination of spinally-administered drugs eventually occurs through the systemic circulation, thus systemic effects and plasma concentrations must be measured to demonstrate systemic safety.

v) The principle characteristic separating pharmacological investigation from one defining safety study is the implementation of systematic histopathology of the target tissues (see [492]). An important implication of the above commentary is that because of the peculiar nature of the intrathecal space as regards local and persistent exposure is that changes in drug delivery profile (bolus vs. infusion), volume or rate of drug delivery and most certainly formulation (pH/osmolarity/ionic or additive content) and most certainly concentration must be considered as defining variables for the characterization of potential toxicity. Our experience with alterations in these variables for intrathecally delivered drugs (e.g., opiates and local anesthetics) emphasizes that such changes can have clear impacts upon the assertion of safety of the formulation.

vi) Adult versus neonate. Finally, it has long been appreciated that neuraxial anesthesia and pain management therapies are relevant to the neonatal and pediatric population. The current concerns over the effects of general anesthetics on neural development in the young population has increased the focus on the neuraxial route. Yet, there has been a paucity of data to indicate the relative safety of neuraxial anesthetics in the same population (see [196, 493-496]. Given issues of pathway development and synaptic connectivity, assessment of the effects of neuraxial agents on concurrent and future spinal function must be considered in further application of analgesics and analgesic agents to this space [491].

\section{SUMMARY}

In summary, the spinal delivery of therapeutic agents reflects upon the role played by the spinal cord in a number of sensory and motor functions and the diverse pharmacological components that are associated with these systems. The initial demonstration of spinal catheterization in the rodent provided a robust model to assess the effects of drugs with an action limited to the spinal cord on behavioral function [497, 498]. The robust and selective effects of spinal opiates on pain behavior first shown in this rodent model (and the growing understanding of the complex algorithms that encode the input-output relationships in the spinal dorsal horn has resulted in exciting advances in the management of these adverse sensations, which, upon arrival at higher centers, initiate the pain experience. 


\section{CONFLICT OF INTEREST}

The authors confirm that this article content has no conflict of interest.

\section{ACKNOWLEDGEMENTS}

Declared none.

\section{REFERENCES}

[1] Price, D.D. Psychological and neural mechanisms of the affective dimension of pain. Science, 2000, 288(5472), 1769-1772. [http:// dx.doi.org/10.1126/science.288.5472.1769] [PMID: 10846154]

[2] Tracey, I.; Mantyh, P.W. The cerebral signature for pain perception and its modulation. Neuron, 2007, 55(3), 377-391. [http://dx.doi. org/10.1016/j.neuron.2007.07.012] [PMID: 17678852]

[3] Vierck, C.J.; Whitsel, B.L.; Favorov, O.V.; Brown, A.W.; Tommerdahl, M. Role of primary somatosensory cortex in the coding of pain. Pain, 2013, 154(3), 334-344. [http://dx.doi.org/ 10.1016/j.pain.2012.10.021] [PMID: 23245864]

[4] Peyron, R.; Laurent, B.; Garcia-Larrea, L. Functional imaging of brain responses to pain. A review and meta-analysis. Clin. Neurophysiol., 2000, 30(5), 263-288. [http://dx.doi.org/10.1016/ S0987-7053(00)00227-6]

[5] Asghar, M.S.; Pereira, M.P.; Werner, M.U.; Mårtensson, J.; Larsson, H.B.; Dahl, J.B. Correction: Secondary Hyperalgesia Phenotypes Exhibit Differences in Brain Activation during Noxious Stimulation. PLoS One, 2015, 10(5), e0128640. [http://dx. doi.org/10.1371/journal.pone.0128640] [PMID: 25978430]

[6] Benson, S.; Rebernik, L.; Wegner, A.; Kleine-Borgmann, J.; Engler, H.; Schlamann, M.; Forsting, M.; Schedlowski, M.; Elsenbruch, S. Neural circuitry mediating inflammation-induced central pain amplification in human experimental endotoxemia. Brain Behav. Immun., 2015, 48, 222-231. [http://dx.doi.org/10.1016/j.bbi.2015. 03.017] [PMID: 25882910]

[7] Treede, R.D.; Meyer, R.A.; Raja, S.N.; Campbell, J.N. Peripheral and central mechanisms of cutaneous hyperalgesia. Prog. Neurobiol., 1992, 38(4), 397-421. [http://dx.doi.org/10.1016/0301-0082(92) 90027-C] [PMID: 1574584]

[8] Kuner, R. Central mechanisms of pathological pain. Nat. Med., 2010, 16(11), 1258-1266. [http://dx.doi.org/10.1038/nm.2231] [PMID: 20948531]

[9] West, S.J.; Bannister, K.; Dickenson, A.H.; Bennett, D.L. Circuitry and plasticity of the dorsal horntoward a better understanding of neuropathic pain. Neuroscience, 2015, 300, 254-275. [http://dx.doi. org/10.1016/j.neuroscience.2015.05.020] [PMID: 25987204]

[10] Yaksh, T.L.; Woller, S.A.; Ramachandran, R.; Sorkin, L.S. The search for novel analgesics: targets and mechanisms. F1000Prime Rep., 2015, 7, 56. [http://dx.doi.org/10.12703/P7-56] [PMID: 26097729]

[11] Ji, R.R.; Xu, Z.Z.; Gao, Y.J. Emerging targets in neuroinflammation-driven chronic pain. Nat. Rev. Drug Discov., 2014, 13(7), 533-548. [http://dx.doi.org/10.1038/nrd4334] [PMID: 24948120]

[12] Reina, M.A.; Villanueva, M.C.; Machés, F.; Carrera, A.; López, A.; De Andrés, J.A. The ultrastructure of the human spinal nerve root cuff in the lumbar spine. Anesth. Analg., 2008, 106(1), 339-344. [table of contents.]. [http://dx.doi.org/10.1213/01.ane.0000295803. 31074.dc] [PMID: 18165601]

[13] Pollay, M. The function and structure of the cerebrospinal fluid outflow system. Cerebrospinal Fluid Res., 2010, 7, 9. [http://dx.doi.org/10.1186/1743-8454-7-9] [PMID: 20565964]

[14] Tonra, J.R.; Mendell, L.M. Rabbit IgG distribution in skin, spinal cord and DRG following systemic injection in rat. J. Neuroimmunol., 1997, 80(1-2), 97-105. [http://dx.doi.org/10.1016/S0165-5728(97) 00140-9] [PMID: 9413264]

[15] McLachlan, E.M.; Jänig, W.; Devor, M.; Michaelis, M. Peripheral nerve injury triggers noradrenergic sprouting within dorsal root ganglia. Nature, 1993, 363(6429), 543-546. [http://dx.doi.org/ 10.1038/363543a0] [PMID: 8505981]

[16] Stevens, C.W. Opioid research in amphibians: an alternative pain model yielding insights on the evolution of opioid receptors. Brain Res. Brain Res. Rev., 2004, 46(2), 204-215. [http://dx.doi.org/ 10.1016/j.brainresrev.2004.07.003] [PMID: 15464208]
[17] Yaksh, T.L. Pharmacology and mechanisms of opioid analgesic activity. Acta Anaesthesiol. Scand., 1997, 41(1 Pt 2), 94-111. [http:// dx.doi.org/10.1111/j.1399-6576.1997.tb04623.x] [PMID: 9061092]

[18] Yaksh, T.L. Spinal opiate analgesia: characteristics and principles of action. Pain, 1981, 11(3), 293-346. [http://dx.doi.org/10.1016/ 0304-3959(81)90633-3] [PMID: 6276842]

[19] Williams, J.T.; Ingram, S.L.; Henderson, G.; Chavkin, C.; von Zastrow, M.; Schulz, S.; Koch, T.; Evans, C.J.; Christie, M.J. Regulation of $\mu$-opioid receptors: desensitization, phosphorylation, internalization, and tolerance. Pharmacol. Rev., 2013, 65(1), 223254. [http://dx.doi.org/10.1124/pr.112.005942] [PMID: 23321159]

[20] Laduron, P.M. Axonal transport of opiate receptors in capsaicinsensitive neurones. Brain Res., 1984, 294(1), 157-160. [http://dx. doi.org/10.1016/0006-8993(84)91322-2] [PMID: 6199089]

[21] Zhang, Q.; Schäffer, M.; Elde, R.; Stein, C. Effects of neurotoxins and hindpaw inflammation on opioid receptor immunoreactivities in dorsal root ganglia. Neuroscience, 1998, 85(1), 281-291. [http:// dx.doi.org/10.1016/S0306-4522(97)00647-7] [PMID: 9607719]

[22] Le Bars, D.; Menétrey, D.; Conseiller, C.; Besson, J.M. Depressive effects of morphine upon lamina $\mathrm{V}$ cells activities in the dorsal horn of the spinal cat. Brain Res., 1975, 98(2), 261-277. [http://dx.doi. org/10.1016/0006-8993(75)90005-0] [PMID: 171029]

[23] Duggan, A.W.; Hall, J.G.; Headley, P.M. Suppression of transmission of nociceptive impulses by morphine: selective effects of morphine administered in the region of the substantia gelatinosa. Br. J. Pharmacol., 1977, 61(1), 65-76. [http://dx.doi.org/10.1111/ j.1476-5381.1977.tb09740.x] [PMID: 199311]

[24] Yaksh, T.L. Inhibition by etorphine of the discharge of dorsal horn neurons: effects on the neuronal response to both high- and lowthreshold sensory input in the decerebrate spinal cat. Exp. Neurol., 1978, 60(1), 23-40. [http://dx.doi.org/10.1016/0014-4886(78)901668] [PMID: 658193]

[25] Dickenson, A.H.; Sullivan, A.F. Electrophysiological studies on the effects of intrathecal morphine on nociceptive neurones in the rat dorsal horn. Pain, 1986, 24(2), 211-222. [http://dx.doi.org/10.1016/ 0304-3959(86)90044-8] [PMID: 3754322]

[26] Kondo, I.; Marvizon, J.C.; Song, B.; Salgado, F.; Codeluppi, S.; Hua, X.Y.; Yaksh, T.L. Inhibition by spinal mu- and delta-opioid agonists of afferent-evoked substance P release. J. Neurosci., 2005, 25(14), 3651-3660. [http://dx.doi.org/10.1523/JNEUROSCI.025205.2005] [PMID: 15814796]

[27] Yaksh, T.L.; Jessell, T.M.; Gamse, R.; Mudge, A.W.; Leeman, S.E. Intrathecal morphine inhibits substance $\mathrm{P}$ release from mammalian spinal cord in vivo. Nature, 1980, 286(5769), 155-157. [http://dx. doi.org/10.1038/286155a0] [PMID: 6157098]

[28] McQuay, H.J.; Moore, R.A. Urinary retention following spinal opiates. Anesthesiology, 1988, 69(3), 441-442. [http://dx.doi.org/ 10.1097/00000542-198809000-00042] [PMID: 2901241]

[29] Atchison, S.R.; Durant, P.A.; Yaksh, T.L. Cardiorespiratory effects and kinetics of intrathecally injected D-Ala2-D-Leu5-enkephalin and morphine in unanesthetized dogs. Anesthesiology, 1986, 65(6), 609-616. [http://dx.doi.org/10.1097/00000542-198612000-00008] [PMID: 3098139]

[30] Sultan, P.; Gutierrez, M.C.; Carvalho, B. Neuraxial morphine and respiratory depression: finding the right balance. Drugs, 2011, 71(14), 1807-1819. [http://dx.doi.org/10.2165/11596250-00000000000000] [PMID: 21942973]

[31] Stevens, C.W.; Yaksh, T.L. Time course characteristics of tolerance development to continuously infused antinociceptive agents in rat spinal cord. J. Pharmacol. Exp. Ther., 1989, 251(1), 216-223. [PMID: 2795458]

[32] Gu, G.; Kondo, I.; Hua, X.Y.; Yaksh, T.L. Resting and evoked spinal substance $\mathrm{P}$ release during chronic intrathecal morphine infusion: parallels with tolerance and dependence. J. Pharmacol. Exp. Ther., 2005, 314(3), 1362-1369. [http://dx.doi.org/10.1124/ jpet.105.087718] [PMID: 15908510]

[33] Yaksh, T.L.; Onofrio, B.M. Retrospective consideration of the doses of morphine given intrathecally by chronic infusion in 163 patients by 19 physicians. Pain, 1987, 31(2), 211-223. [http://dx. doi.org/10.1016/0304-3959(87)90037-6] [PMID: 3431881]

[34] Anderson, V.C.; Burchiel, K.J. A prospective study of long-term intrathecal morphine in the management of chronic nonmalignant pain. Neurosurgery, 1999, 44(2), 289-300. [http://dx.doi.org/ 10.1097/00006123-199902000-00026] [PMID: 9932882] 
[35] Shaladi, A.; Saltari, M.R.; Piva, B.; Crestani, F.; Tartari, S.; Pinato, P.; Micheletto, G.; DallAra, R. Continuous intrathecal morphine infusion in patients with vertebral fractures due to osteoporosis. Clin. J. Pain, 2007, 23(6), 511-517. [http://dx.doi.org/10.1097/AJP. 0b013e31806a23d4] [PMID: 17575491]

[36] Duarte, R.V.; Raphael, J.H.; Haque, M.S.; Southall, J.L.; Ashford, R.L. A predictive model for intrathecal opioid dose escalation for chronic non-cancer pain. Pain Phys., 2012, 15(5), 363-369. [PMID: 22996848]

[37] Prager, J.; Deer, T.; Levy, R.; Bruel, B.; Buchser, E.; Caraway, D.; Cousins, M.; Jacobs, M.; McGlothlen, G.; Rauck, R.; Staats, P.; Stearns, L. Best practices for intrathecal drug delivery for pain. Neuromodulation, 2014, 17(4), 354-372.

[38] Ummenhofer, W.C.; Arends, R.H.; Shen, D.D.; Bernards, C.M. Comparative spinal distribution and clearance kinetics of intrathecally administered morphine, fentanyl, alfentanil, and sufentanil. Anesthesiology, 2000, 92(3), 739-753. [http://dx.doi.org/10.1097/ 00000542-200003000-00018] [PMID: 10719953]

[39] Bernards, C.M. Understanding the physiology and pharmacology of epidural and intrathecal opioids. Best Pract. Res. Clin. Anaesthesiol., 2002, 16(4), 489-505. [http://dx.doi.org/10.1053/bean.2002.0255] [PMID: 12516887]

[40] Bernards, C.M. Recent insights into the pharmacokinetics of spinal opioids and the relevance to opioid selection. Curr. Opin. Anaesthesiol., 2004, 17(5), 441-447. [http://dx.doi.org/10.1097/ 00001503-200410000-00015] [PMID: 17023903]

[41] Ruan, X. Drug-related side effects of long-term intrathecal morphine therapy. Pain Phys., 2007, 10(2), 357-366. [PMID: 17387357]

[42] Deer, T. R.; Levy, R.; Prager, J.; Buchser, E.; Burton, A.; Caraway, D.; Cousins, M.; De Andres, J.; Diwan, S.; Erdek, M.; Grigsby, E.; Huntoon, M.; Jacobs, M. S.; Kim, P.; Kumar, K.; Leong, M.; Liem, L.; McDowell, G. C., 2nd; Panchal, S.; Rauck, R.; Saulino, M.; Sitzman, B. T.; Staats, P.; Stanton-Hicks, M.; Stearns, L.; Wallace, M.; Willis, K. D.; Witt, W.; Yaksh, T.; Mekhail, N. Polyanalgesic Consensus Conference--2012: recommendations to reduce morbidity and mortality in intrathecal drug delivery in the treatment of chronic pain. Neuromodulation, 2012, 15(5), 467-482.

[43] Yaksh, T.; Wallace, M.S. Opioids, analgesia, and pain management. In: Goodman \& Gilman's The Pharmacological Basis of Therapeutics; Brunton, L.; Chabner, B.; Knollman, B., Eds.; McGraw -Hill Medical: New York, 2011; pp. 481-526.

[44] de Groat, W.C. Anatomy of the central neural pathways controlling the lower urinary tract. Eur. Urol., 1998, 34(Suppl. 1), 2-5. [http:// dx.doi.org/10.1159/000052265] [PMID: 9705544]

[45] Durant, P.A.; Yaksh, T.L. Drug effects on urinary bladder tone during spinal morphine-induced inhibition of the micturition reflex in unanesthetized rats. Anesthesiology, 1988, 68(3), 325-334. [http:// dx.doi.org/10.1097/00000542-198803000-00002] [PMID: 3344988]

[46] Herman, R.M.; Wainberg, M.C.; delGiudice, P.F.; Willscher, M.K. The effect of a low dose of intrathecal morphine on impaired micturition reflexes in human subjects with spinal cord lesions. Anesthesiology, 1988, 69(3), 313-318. [http://dx.doi.org/10.1097/ 00000542-198809000-00005] [PMID: 3415012]

[47] Levy, J.H.; Brister, N.W.; Shearin, A.; Ziegler, J.; Hug, C.C., Jr; Adelson, D.M.; Walker, B.F. Wheal and flare responses to opioids in humans. Anesthesiology, 1989, 70(5), 756-760. [http://dx.doi. org/10.1097/00000542-198905000-00008] [PMID: 2470272]

[48] Kumar, K.; Singh, S.I. Neuraxial opioid-induced pruritus: An update. J. Anaesthesiol. Clin. Pharmacol., 2013, 29(3), 303-307. [http://dx.doi.org/10.4103/0970-9185.117045] [PMID: 24106351]

[49] Yaksh, T.L.; Horais, K.A.; Tozier, N.A.; Allen, J.W.; Rathbun, M.; Rossi, S.S.; Sommer, C.; Meschter, C.; Richter, P.J.; Hildebrand, K.R. Chronically infused intrathecal morphine in dogs. Anesthesiology, 2003, 99(1), 174-187. [http://dx.doi.org/10.1097/ 00000542-200307000-00028] [PMID: 12826858]

[50] Gradert, T.L.; Baze, W.B.; Satterfield, W.C.; Hildebrand, K.R.; Johansen, M.J.; Hassenbusch, S.J. Safety of chronic intrathecal morphine infusion in a sheep model. Anesthesiology, 2003, 99(1), 188-198. [http://dx.doi.org/10.1097/00000542-200307000-00029] [PMID: 12826859]

[51] Allen, J.W.; Horais, K.A.; Tozier, N.A.; Wegner, K.; Corbeil, J.A.; Mattrey, R.F.; Rossi, S.S.; Yaksh, T.L. Time course and role of morphine dose and concentration in intrathecal granuloma formation in dogs: a combined magnetic resonance imaging and histopathology investigation. Anesthesiology, 2006, 105(3), 581589. [http://dx.doi.org/10.1097/00000542-200609000-00024] [PMID: 16931993]

[52] Allen, J.W.; Horais, K.A.; Tozier, N.A.; Yaksh, T.L. Opiate pharmacology of intrathecal granulomas. Anesthesiology, 2006, 105(3), 590-598. [http://dx.doi.org/10.1097/00000542-20060900000025] [PMID: 16931994]

[53] Yaksh, T. L.; Steinauer, J. J.; Veesart, S. L.; Malkmus, S. A. Alfentanil: Correlations Between Absence of Effect Upon Subcutaneous Mast Cells and Absence of Granuloma Formation After Intrathecal Infusion in the Dog. Neuromodulation, 2013 16(5), 459-466.

[54] Yaksh, T.L.; Allen, J.W.; Veesart, S.L.; Horais, K.A.; Malkmus, S.A.; Scadeng, M.; Steinauer, J.J.; Rossi, S.S. Role of meningeal mast cells in intrathecal morphine-evoked granuloma formation. Anesthesiology, 2013, 118(3), 664-678. [http://dx.doi.org/10.1097/ ALN.0b013e31828351aa] [PMID: 23426209]

[55] Michael, A.; Buffen, E.; Rauck, R.; Anderson, W.; McGirt, M.; Mendenhall, H.V. An in vivo canine study to assess granulomatous responses in the MedStream Programmable Infusion System (TM) and the SynchroMed II Infusion System ${ }^{\circledR}$. Pain Med., 2012, 13(2), 175-184. [http://dx.doi.org/10.1111/j.1526-4637.2011.01308.x] [PMID: 22239738]

[56] Johansen, M.J.; Satterfield, W.C.; Baze, W.B.; Hildebrand, K.R.; Gradert, T.L.; Hassenbusch, S.J. Continuous intrathecal infusion of hydromorphone: safety in the sheep model and clinical implications. Pain Med., 2004, 5(1), 14-25. [http://dx.doi.org/10.1111/j.15264637.2004.04010.x] [PMID: 14996233]

[57] Deer, T. R.; Prager, J.; Levy, R.; Rathmell, J.; Buchser, E.; Burton, A.; Caraway, D.; Cousins, M.; De Andres, J.; Diwan, S.; Erdek, M.; Grigsby, E.; Huntoon, M.; Jacobs, M. S.; Kim, P.; Kumar, K.; Leong, M.; Liem, L.; McDowell, G. C., 2nd; Panchal, S.; Rauck, R.; Saulino, M.; Sitzman, B. T.; Staats, P.; Stanton-Hicks, M.; Stearns, L.; Wallace, M.; Willis, K. D.; Witt, W.; Yaksh, T.; Mekhail, N. Polyanalgesic Consensus Conference--2012: consensus on diagnosis, detection, and treatment of catheter-tip granulomas (inflammatory masses). Neuromodulation, 2012, 15(5), 483-495.

[58] Law, P.Y.; Reggio, P.H.; Loh, H.H. Opioid receptors: toward separation of analgesic from undesirable effects. Trends Biochem. Sci., 2013, 38(6), 275-282. [http://dx.doi.org/10.1016/j.tibs.2013. 03.003] [PMID: 23598157]

[59] Pasternak, G.W. Opioids and their receptors: Are we there yet? Neuropharmacology, 2014, 76(Pt B), 198-203. [http://dx.doi.org/ 10.1016/j.neuropharm.2013.03.039] [PMID: 23624289]

[60] Lamberts, J.T.; Traynor, J.R. Opioid receptor interacting proteins and the control of opioid signaling. Curr. Pharm. Des., 2013, 19(42), 7333-7347. [http://dx.doi.org/10.2174/138161281942140105160625] [PMID: 23448476]

[61] Raehal, K.M.; Bohn, L.M. $\beta$-arrestins: regulatory role and therapeutic potential in opioid and cannabinoid receptor-mediated analgesia. Handbook Exp. Pharmacol., 2014, 219, 427-443. [http:// dx.doi.org/10.1007/978-3-642-41199-1_22] [PMID: 24292843]

[62] Violin, J.D.; Crombie, A.L.; Soergel, D.G.; Lark, M.W. Biased ligands at $\mathrm{G}$ protein-coupled receptors: promise and progress (vol 35, pg 308, 2014). Trends Pharmacol. Sci., 2014, 35(9), 489-489. [http://dx.doi.org/10.1016/j.tips.2014.07.005]

[63] Alfaras-Melainis, K.; Gomes, I.; Rozenfeld, R.; Zachariou, V.; Devi, L. Modulation of opioid receptor function by protein-protein interactions. Front. Biosci. (Landmark Ed.), 2009, 14, 3594-3607. [http://dx.doi.org/10.2741/3474] [PMID: 19273296]

[64] Fujita, W.; Gomes, I.; Devi, L.A. Heteromers of $\mu-\delta$ opioid receptors: new pharmacology and novel therapeutic possibilities. Br. J. Pharmacol., 2015, 172(2), 375-387. [http://dx.doi.org/10. 1111/bph.12663] [PMID: 24571499]

[65] Bird, M.F.; Lambert, D.G. Simultaneous targeting of multiple opioid receptor types. Curr. Opin. Support. Palliat. Care, 2015, 9(2), 98-102. [http://dx.doi.org/10.1097/SPC.0000000000000129] [PMID: 25872121]

[66] Le Naour, M.; Akgün, E.; Yekkirala, A.; Lunzer, M.M.; Powers, M.D.; Kalyuzhny, A.E.; Portoghese, P.S. Bivalent ligands that target $\mu$ opioid (MOP) and cannabinoid1 (CB1) receptors are potent analgesics devoid of tolerance. J. Med. Chem., 2013, 56(13), 55055513. [http://dx.doi.org/10.1021/jm4005219] [PMID: 23734559]

[67] Smeester, B.A.; Lunzer, M.M.; Akgün, E.; Beitz, A.J.; Portoghese, P.S. Targeting putative $\mathrm{mu}$ opioid/metabotropic glutamate receptor- 
5 heteromers produces potent antinociception in a chronic murine bone cancer model. Eur. J. Pharmacol., 2014, 743, 48-52. [http:// dx.doi.org/10.1016/j.ejphar.2014.09.008] [PMID: 25239072]

[68] Akgün, E.; Javed, M.I.; Lunzer, M.M.; Smeester, B.A.; Beitz, A.J.; Portoghese, P.S. Ligands that interact with putative MOR-mGluR5 heteromer in mice with inflammatory pain produce potent antinociception. Proc. Natl. Acad. Sci. USA, 2013, 110(28), 11595-11599. [http://dx.doi.org/10.1073/pnas.1305461110] [PMID: 23798416]

[69] Normandin, A.; Luccarini, P.; Molat, J.L.; Gendron, L.; Dallel, R. Spinal $\mu$ and $\delta$ opioids inhibit both thermal and mechanical pain in rats. J. Neurosci., 2013, 33(28), 11703-11714. [http://dx.doi.org/ 10.1523/JNEUROSCI.1631-13.2013] [PMID: 23843537]

[70] Tung, A.S.; Yaksh, T.L. In vivo evidence for multiple opiate receptors mediating analgesia in the rat spinal cord. Brain Res., 1982, 247(1), 75-83. [http://dx.doi.org/10.1016/0006-8993(82)910290] [PMID: 6127147]

[71] Porreca, F.; Heyman, J.S.; Mosberg, H.I.; Omnaas, J.R.; Vaught, J.L. Role of mu and delta receptors in the supraspinal and spinal analgesic effects of [D-Pen2, D-Pen5] enkephalin in the mouse. $J$. Pharmacol. Exp. Ther., 1987, 241(2), 393-400. [PMID: 3033214]

[72] Stewart, P.E.; Hammond, D.L. Activation of spinal delta-1 or delta2 opioid receptors reduces carrageenan-induced hyperalgesia in the rat. J. Pharmacol. Exp. Ther., 1994, 268(2), 701-708. [PMID: 8113981]

[73] Nagasaka, H.; Yaksh, T.L. Effects of intrathecal mu, delta, and kappa agonists on thermally evoked cardiovascular and nociceptive reflexes in halothane-anesthetized rats. Anesth. Analg., 1995, 80(3), 437-443. [PMID: 7864404]

[74] Kouchek, M.; Takasusuki, T.; Terashima, T.; Yaksh, T.L.; Xu, Q. Effects of intrathecal SNC80, a delta receptor ligand, on nociceptive threshold and dorsal horn substance p release. J. Pharmacol. Exp. Ther., 2013, 347(2), 258-264. [http://dx.doi.org/10.1124/jpet.113. 206573] [PMID: 23978562]

[75] Russell, R.D.; Leslie, J.B.; Su, Y.F.; Watkins, W.D.; Chang, K.J. Continuous intrathecal opioid analgesia: tolerance and crosstolerance of $\mathrm{mu}$ and delta spinal opioid receptors. J. Pharmacol. Exp. Ther., 1987, 240(1), 150-158. [PMID: 3027302]

[76] Stevens, C.W.; Yaksh, T.L. Studies of morphine and D-ala2D-leu5-enkephalin (DADLE) cross-tolerance after continuous intrathecal infusion in the rat. Anesthesiology, 1992, 76(4), 596603. [http://dx.doi.org/10.1097/00000542-199204000-00017] [PMID: 1550284]

[77] Joseph, E.K.; Levine, J.D. Mu and delta opioid receptors on nociceptors attenuate mechanical hyperalgesia in rat. Neuroscience, 2010, 171(1), 344-350. [http://dx.doi.org/10.1016/j.neuroscience. 2010.08.035] [PMID: 20736053]

[78] Scherrer, G.; Imamachi, N.; Cao, Y.Q.; Contet, C.; Mennicken, F.; ODonnell, D.; Kieffer, B.L.; Basbaum, A.I. Dissociation of the opioid receptor mechanisms that control mechanical and heat pain. Cell, 2009, 137(6), 1148-1159. [http://dx.doi.org/10.1016/j.cell. 2009.04.019] [PMID: 19524516]

[79] Bardoni, R.; Tawfik, V.L.; Wang, D.; François, A.; Solorzano, C.; Shuster, S.A.; Choudhury, P.; Betelli, C.; Cassidy, C.; Smith, K.; de Nooij, J.C.; Mennicken, F.; ODonnell, D.; Kieffer, B.L.; Woodbury, C.J.; Basbaum, A.I.; MacDermott, A.B.; Scherrer, G. Delta opioid receptors presynaptically regulate cutaneous mechanosensory neuron input to the spinal cord dorsal horn. Neuron, 2014, 81(6), 1312-1327. [http://dx.doi.org/10.1016/j. neuron.2014.01.044] [PMID: 24583022]

[80] Yaksh, T.L. Substance P release from knee joint afferent terminals: modulation by opioids. Brain Res., 1988, 458(2), 319-324. [http:// dx.doi.org/10.1016/0006-8993(88)90474-X] [PMID: 2463049]

[81] Aimone, L.D.; Yaksh, T.L. Opioid modulation of capsaicin-evoked release of substance $\mathrm{P}$ from rat spinal cord in vivo. Peptides, 1989, 10(6), 1127-1131. [http://dx.doi.org/10.1016/0196-9781(89)90003X] [PMID: 2482963]

[82] Beaudry, H.; Dubois, D.; Gendron, L. Activation of spinal muand delta-opioid receptors potently inhibits substance $\mathrm{P}$ release induced by peripheral noxious stimuli. J. Neurosci., 2011, 31(37), 13068-13077. [http://dx.doi.org/10.1523/JNEUROSCI.1817-11.2011] [PMID: 21917790]

[83] Onofrio, B.M.; Yaksh, T.L. Intrathecal delta-receptor ligand produces analgesia in man. Lancet, 1983, 1(8338), 1386-1387. [http://dx.doi. org/10.1016/S0140-6736(83)92170-0] [PMID: 6134164]
[84] Moulin, D.E.; Max, M.B.; Kaiko, R.F.; Inturrisi, C.E.; Maggard, J.; Yaksh, T.L.; Foley, K.M. The analgesic efficacy of intrathecal DAla2-D-Leu5-enkephalin in cancer patients with chronic pain. Pain, 1985, 23(3), 213-221. [http://dx.doi.org/10.1016/03043959(85)90099-5] [PMID: 3906516]

[85] Shimoyama, M.; Shimoyama, N.; Zhao, G.M.; Schiller, P.W.; Szeto, H.H. Antinociceptive and respiratory effects of intrathecal H-Tyr-D-Arg-Phe-Lys-NH2 (DALDA) and [Dmt1] DALDA. $J$. Pharmacol. Exp. Ther., 2001, 297(1), 364-371. [PMID: 11259564]

[86] Svensson, C.I.; Rew, Y.; Malkmus, S.; Schiller, P.W.; Taulane, J.P.; Goodman, M.; Yaksh, T.L. Systemic and spinal analgesic activity of a delta-opioid-selective lanthionine enkephalin analog. J. Pharmacol. Exp. Ther., 2003, 304(2), 827-832. [http://dx.doi. org/10.1124/jpet.102.039750] [PMID: 12538839]

[87] Yaksh, T.L. Pharmacology of spinal adrenergic systems which modulate spinal nociceptive processing. Pharmacol. Biochem. Behav., 1985, 22(5), 845-858. [http://dx.doi.org/10.1016/00913057(85)90537-4] [PMID: 2861606]

[88] Pertovaara, A. The noradrenergic pain regulation system: a potential target for pain therapy. Eur. J. Pharmacol., 2013, 716(1-3), 2-7. [http://dx.doi.org/10.1016/j.ejphar.2013.01.067] [PMID: 23500194]

[89] Ruffolo, R.R., Jr; Hieble, J.P. Alpha-adrenoceptors. Pharmacol. Ther., 1994, 61(1-2), 1-64. [http://dx.doi.org/10.1016/0163-7258 (94)90058-2] [PMID: 7938167]

[90] Nicholson, R.; Dixon, A.K.; Spanswick, D.; Lee, K. Noradrenergic receptor mRNA expression in adult rat superficial dorsal horn and dorsal root ganglion neurons. Neurosci. Lett., 2005, 380(3), 316-321. [http://dx.doi.org/10.1016/j.neulet.2005.01.079] [PMID: 15862909]

[91] Stone, L.S.; Broberger, C.; Vulchanova, L.; Wilcox, G.L.; Hökfelt, T.; Riedl, M.S.; Elde, R. Differential distribution of alpha2A and alpha2C adrenergic receptor immunoreactivity in the rat spinal cord. J. Neurosci., 1998, 18(15), 5928-5937. [PMID: 9671679]

[92] Pan, Y.Z.; Li, D.P.; Pan, H.L. Inhibition of glutamatergic synaptic input to spinal lamina II(o) neurons by presynaptic alpha(2)adrenergic receptors. J. Neurophysiol., 2002, 87(4), 1938-1947. [http://dx.doi.org/10.1152/jn.00575.2001] [PMID: 11929913]

[93] Kawasaki, Y.; Kumamoto, E.; Furue, H.; Yoshimura, M. Alpha 2 adrenoceptor-mediated presynaptic inhibition of primary afferent glutamatergic transmission in rat substantia gelatinosa neurons. Anesthesiology, 2003, 98(3), 682-689. [http://dx.doi.org/10.1097/ 00000542-200303000-00016] [PMID: 12606912]

[94] Sonohata, M.; Furue, H.; Katafuchi, T.; Yasaka, T.; Doi, A.; Kumamoto, E.; Yoshimura, M. Actions of noradrenaline on substantia gelatinosa neurones in the rat spinal cord revealed by in vivo patch recording. J. Physiol., 2004, 555(Pt 2), 515-526. [http:// dx.doi.org/10.1113/jphysiol.2003.054932] [PMID: 14673188]

[95] Millan, M.J. Descending control of pain. Prog. Neurobiol., 2002, 66(6), 355-474. [http://dx.doi.org/10.1016/S0301-0082(02)000096] [PMID: 12034378]

[96] Nazarian, A.; Christianson, C.A.; Hua, X.Y.; Yaksh, T.L. Dexmedetomidine and ST-91 analgesia in the formalin model is mediated by alpha2A-adrenoceptors: a mechanism of action distinct from morphine. Br. J. Pharmacol., 2008, 155(7), $1117-$ 1126. [http://dx.doi.org/10.1038/bjp.2008.341] [PMID: 18846040]

[97] Yaksh, T.L.; Pogrel, J.W.; Lee, Y.W.; Chaplan, S.R. Reversal of nerve ligation-induced allodynia by spinal alpha-2 adrenoceptor agonists. J. Pharmacol. Exp. Ther., 1995, 272(1), 207-214. [PMID: 7815335]

[98] Takano, Y.; Yaksh, T.L. Characterization of the pharmacology of intrathecally administered alpha- 2 agonists and antagonists in rats. $J$. Pharmacol. Exp. Ther., 1992, 261(2), 764-772. [PMID: 1349648]

[99] Yaksh, T.L.; Hua, X.Y.; Kalcheva, I.; Nozaki-Taguchi, N.; Marsala, M. The spinal biology in humans and animals of pain states generated by persistent small afferent input. Proc. Natl. Acad. Sci. USA, 1999, 96(14), 7680-7686. [http://dx.doi.org/10.1073/pnas.96. 14.7680] [PMID: 10393880]

[100] Levy, R.; Leiphart, J.; Dills, C. Analgesic action of acute and chronic intraspinally administered opiate and alpha 2-adrenergic agonists in chronic neuropathic pain. Stereotact. Funct. Neurosurg., 1994, 62(1-4), 279-289. [http://dx.doi.org/10.1159/000098633] [PMID: 7631082]

[101] Stevens, C.W.; Monasky, M.S.; Yaksh, T.L. Spinal infusion of opiate and alpha-2 agonists in rats: tolerance and cross-tolerance 
studies. J. Pharmacol. Exp. Ther., 1988, 244(1), 63-70. [PMID: 2891846]

[102] Capogna, G.; Celleno, D.; Zangrillo, A.; Costantino, P.; Foresta, S. Addition of clonidine to epidural morphine enhances postoperative analgesia after cesarean delivery. Reg. Anesth., 1995, 20(1), 57-61. [PMID: 7727330]

[103] Engelman, E.; Marsala, C. Efficacy of adding clonidine to intrathecal morphine in acute postoperative pain: meta-analysis. $\mathrm{Br}$. J. Anaesth., 2013, 110(1), 21-27. [http://dx.doi.org/10.1093/bja/ aes344] [PMID: 23002167]

[104] Yaksh, T.L.; Rathbun, M.; Jage, J.; Mirzai, T.; Grafe, M.; Hiles, R.A. Pharmacology and toxicology of chronically infused epidural clonidine. $\mathrm{HCl}$ in dogs. Fundam. App. Toxicol., 1994, 23(3), 319-335.

[105] Dowlatshahi, P.; Yaksh, T.L. Differential effects of two intraventricularly injected alpha 2 agonists, ST-91 and dexmedetomidine, on electroencephalogram, feeding, and electromyogram. Anesth. Analg., 1997, 84(1), 133-138. [http://dx.doi.org/10.1213/00000539199701000-00025] [PMID: 8989014]

[106] Buerkle, H.; Boschin, M.; Marcus, M.A.; Brodner, G.; Wüsten, R.; Van Aken, H. Central and peripheral analgesia mediated by the acetylcholinesterase-inhibitor neostigmine in the rat inflamed knee joint model. Anesth. Analg., 1998, 86(5), 1027-1032. [http://dx. doi.org/10.1213/00000539-199805000-00023] [PMID: 9585291]

[107] Knaus, A.E.; Muthig, V.; Schickinger, S.; Moura, E.; Beetz, N.; Gilsbach, R.; Hein, L. Alpha2-adrenoceptor subtypesunexpected functions for receptors and ligands derived from gene-targeted mouse models. Neurochem. Int., 2007, 51(5), 277-281. [http://dx. doi.org/10.1016/j.neuint.2007.06.036] [PMID: 17664025]

[108] Bier, A. Experiments regarding the cocainization of the spinal cord. Dtsch Z Chir, 1899, 51, 361-369. [http://dx.doi.org/10.1007/ BF02792160]

[109] Matas, R. Local and regional anesthesiawith cocaine and other analgesic drugs, including the subarachnoid method, as applied in the general surgical practice. Phil. Med. J., 1900, 6, 820-843.

[110] Vandam, L.D. On the origins of intrathecal anesthesia. Reg. Anesth. Pain Med., 1998, 23(4), 335-339. [PMID: 9690581]

[111] Akerman, B.; Arweström, E.; Post, C. Local anesthetics potentiate spinal morphine antinociception. Anesth. Analg., 1988, 67(10), 943-948. [PMID: 3421498]

[112] Penning, J.P.; Yaksh, T.L. Interaction of intrathecal morphine with bupivacaine and lidocaine in the rat. Anesthesiology, 1992, 77(6), 1186-2000. [http://dx.doi.org/10.1097/00000542-199212000-00021] [PMID: 1466469]

[113] Saito, Y.; Kaneko, M.; Kirihara, Y.; Sakura, S.; Kosaka, Y. Interaction of intrathecally infused morphine and lidocaine in rats (part I): synergistic antinociceptive effects. Anesthesiology, 1998, 89(6), 1455-1463. [http://dx.doi.org/10.1097/00000542-19981200000023] [PMID: 9856720]

[114] Wu, H.H.; Yin, J.B.; Zhang, T.; Cui, Y.Y.; Dong, Y.L.; Chen, G.Z.; Wang, W. Inhibiting spinal neuron-astrocytic activation correlates with synergistic analgesia of dexmedetomidine and ropivacaine. PLoS One, 2014, 9(3), e92374. [http://dx.doi.org/10.1371/journal. pone.0092374] [PMID: 24658263]

[115] Stocks, G.M.; Hallworth, S.P.; Fernando, R.; England, A.J.; Columb, M.O.; Lyons, G. Minimum local analgesic dose of intrathecal bupivacaine in labor and the effect of intrathecal fentanyl. Anesthesiology, 2001, 94(4), 593-598. [http://dx.doi.org/ 10.1097/00000542-200104000-00011]

[116] Deer, T.; Krames, E.S.; Hassenbusch, S.J.; Burton, A.; Caraway, D.; Dupen, S.; Eisenach, J.; Erdek, M.; Grigsby, E.; Kim, P.; Levy, R.; McDowell, G.; Mekhail, N.; Panchal, S.; Prager, J.; Rauck, R.; Saulino, M.; Sitzman, T.; Staats, P.; Stanton-Hicks, M.; Stearns, L.; Willis, K.D.; Witt, W.; Follett, K.; Huntoon, M.; Liem, L.; Rathmell, J.; Wallace, M.; Buchser, E.; Cousins, M. Polyanalgesic consensus conference 2007: recommendations for the management of pain by intrathecal (intraspinal) drug delivery: report of an interdisciplinary expert panel. Neuromodulation, 2007, 10(4), 300-328.

[117] Veizi, I.E.; Hayek, S.M.; Narouze, S.; Pope, J.E.; Mekhail, N. Combination of intrathecal opioids with bupivacaine attenuates opioid dose escalation in chronic noncancer pain patients. Pain Med., 2011, 12(10), 1481-1489. [http://dx.doi.org/10.1111/j.15264637.2011.01232.x] [PMID: 21943351]

[118] Mercadante, S.; Villari, P.; Ferrera, P.; Arcuri, E. Local anesthetic switching for intrathecal tachyphylaxis in cancer patients with pain.
Anesth. Analg., 2003, 97(1), 187-189. [http://dx.doi.org/10.1213/ 01.ANE.0000067403.15926.BD] [PMID: 12818964]

[119] Kongsgaard, U.E.; Werner, M.U. Tachyphylaxis to local anaesthetics. What is the clinical evidence? A systematic review. Acta Anaesthesiol. Scand., 2015. [PMID: 26358179]

[120] Strichartz, G.R. Neural Physiology and Local Anesthetic Action. In: Neural Blockade in Clinical Anesthesia and Management of Pain, CMaB, P.; Lippincot-Raven: Philadelphia, PA, 1998.

[121] Catterall, W.A.; Goldin, A.L.; Waxman, S.G. International Union of Pharmacology. XLVII. Nomenclature and structure-function relationships of voltage-gated sodium channels. Pharmacol. Rev., 2005, 57(4), 397-409. [http://dx.doi.org/10.1124/pr.57.4.4] [PMID: 16382098]

[122] Gokin, A.P.; Philip, B.; Strichartz, G.R. Preferential block of small myelinated sensory and motor fibers by lidocaine: in vivo electrophysiology in the rat sciatic nerve. Anesthesiology, 2001, 95(6), 1441-1454. [http://dx.doi.org/10.1097/00000542-20011200000025] [PMID: 11748404]

[123] Scholz, A. Mechanisms of (local) anaesthetics on voltage-gated sodium and other ion channels. Br. J. Anaesth., 2002, 89(1), 52-61. [http://dx.doi.org/10.1093/bja/aef163] [PMID: 12173241]

[124] Docherty, R.J.; Farmer, C.E. The pharmacology of voltage-gated sodium channels in sensory neurones. Handbook Exp. Pharmacol., 2009, 194(194), 519-561. [http://dx.doi.org/10.1007/978-3-540-790907 15] [PMID: 19655117]

[125] Stoney, S.D., Jr Limitations on impulse conduction at the branch point of afferent axons in frog dorsal root ganglion. Exp. Brain Res., 1990, 80(3), 512-524. [http://dx.doi.org/10.1007/ BF00227992] [PMID: 2387351]

[126] Theile, J.W.; Cummins, T.R. Recent developments regarding voltage-gated sodium channel blockers for the treatment of inherited and acquired neuropathic pain syndromes. Front. Pharmacol., 2011, 2, 54. [http://dx.doi.org/10.3389/fphar.2011. 00054] [PMID: 22007172]

[127] Wang, W.; Gu, J.; Li, Y.Q.; Tao, Y.X. Are voltage-gated sodium channels on the dorsal root ganglion involved in the development of neuropathic pain? Mol. Pain, 2011, 7, 16. [http://dx.doi.org/ 10.1186/1744-8069-7-16] [PMID: 21345196]

[128] Nieto, F.R.; Cobos, E.J.; Tejada, M.A.; Sánchez-Fernández, C.; González-Cano, R.; Cendán, C.M. Tetrodotoxin (TTX) as a therapeutic agent for pain. Mar. Drugs, 2012, 10(2), 281-305. [http://dx.doi.org/10.3390/md10020281] [PMID: 22412801]

[129] Aurilio, C.; Pota, V.; Pace, M.C.; Passavanti, M.B.; Barbarisi, M. Ionic channels and neuropathic pain: physiopathology and applications. J. Cell. Physiol., 2008, 215(1), 8-14. [http://dx.doi. org/10.1002/jcp.21280] [PMID: 18205177]

[130] Liu, M.; Wood, J.N. The roles of sodium channels in nociception: implications for mechanisms of neuropathic pain. Pain Med., 2011, 12(Suppl. 3), S93-S99. [http://dx.doi.org/10.1111/j.1526-4637. 2011.01158.x] [PMID: 21752183]

[131] Kharatmal, S.B.; Singh, J.N.; Sharma, S.S. Voltage-Gated Sodium Channels as Therapeutic Targets for Treatment of Painful Diabetic Neuropathy. Mini Rev. Med. Chem., 2015, 15(14), 1134-1147. [http://dx.doi.org/10.2174/1389557515666150722112621] [PMID 26202189]

[132] Waxman, S.G. Painful Na-channelopathies: an expanding universe Trends Mol. Med., 2013, 19(7), 406-409. [http://dx.doi.org/10 1016/j.molmed.2013.04.003] [PMID: 23664154]

[133] Brouwer, B.A.; Merkies, I.S.; Gerrits, M.M.; Waxman, S.G.; Hoeijmakers, J.G.; Faber, C.G. Painful neuropathies: the emerging role of sodium channelopathies. J. Peripher. Nerv. Syst., 2014, 19(2), 53-65. [http://dx.doi.org/10.1111/jns5.12071] [PMID: 25250524]

[134] Yanagidate, F.; Strichartz, G.R. Local anesthetics. Handbook Exp. Pharmacol., 2007, (177), 95-127. [PMID: 17087121]

[135] Lirk, P.; Picardi, S.; Hollmann, M.W. Local anaesthetics: 10 essentials. Eur. J. Anaesthesiol., 2014, 31(11), 575-585. [http://dx. doi.org/10.1097/EJA.0000000000000137] [PMID: 25192265]

[136] Zaric, D.; Christiansen, C.; Pace, N.L.; Punjasawadwong, Y. Transient neurologic symptoms after spinal anesthesia with lidocaine versus other local anesthetics: a systematic review of randomized, controlled trials. Anesth. Analg., 2005, 100(6), 18111816. [http://dx.doi.org/10.1213/01.ANE.0000136844.87857.78] [PMID: 15920219]

[137] Yamashita, A.; Matsumoto, M.; Matsumoto, S.; Itoh, M.; Kawai, K.; Sakabe, T. A comparison of the neurotoxic effects on the spinal 
cord of tetracaine, lidocaine, bupivacaine, and ropivacaine administered intrathecally in rabbits. Anesth. Analg., 2003, 97(2), 512-519. [table of contents.]. [http://dx.doi.org/10.1213/01.ANE. 0000068885.78816.5B] [PMID: 12873946]

[138] Guo, J.; Lv, N.; Su, Y.; Liu, Y.; Zhang, J.; Yang, D. Effects of intrathecal anesthesia with different concentrations and doses on spinal cord, nerve roots and cerebrospinal fluid in dogs. Int. J. Clin. Exp. Med., 2014, 7(12), 5376-5384. [PMID: 25664046]

[139] Sakura, S.; Bollen, A.W.; Ciriales, R.; Drasner, K. Local anesthetic neurotoxicity does not result from blockade of voltage-gated sodium channels. Anesth. Analg., 1995, 81(2), 338-346. [PMID: 7618726]

[140] Kitagawa, N.; Oda, M.; Nobutaka, I.; Satoh, H.; Totoki, T.; Morimoto, M. A proposed mechanism for amitriptyline neurotoxicity based on its detergent nature. Toxicol. Appl. Pharmacol., 2006, 217(1), 100-106. [http://dx.doi.org/10.1016/j.taap.2006.08.003] [PMID: $16978678]$

[141] Gold, M.S.; Reichling, D.B.; Hampl, K.F.; Drasner, K.; Levine, J.D. Lidocaine toxicity in primary afferent neurons from the rat. $J$. Pharmacol. Exp. Ther., 1998, 285(2), 413-421. [PMID: 9580578]

[142] England, S.; de Groot, M.J. Subtype-selective targeting of voltagegated sodium channels. Br. J. Pharmacol., 2009, 158(6), 14131425. [http://dx.doi.org/10.1111/j.1476-5381.2009.00437.x] [PMID: 19845672]

[143] Clare, J.J. Targeting voltage-gated sodium channels for pain therapy. Expert Opin. Investig. Drugs, 2010, 19(1), 45-62. [http://dx.doi. org/10.1517/13543780903435340] [PMID: 20001554]

[144] Schmalhofer, W.A.; Calhoun, J.; Burrows, R.; Bailey, T.; Kohler, M.G.; Weinglass, A.B.; Kaczorowski, G.J.; Garcia, M.L.; Koltzenburg, M.; Priest, B.T. ProTx-II, a selective inhibitor of NaV1.7 sodium channels, blocks action potential propagation in nociceptors. Mol. Pharmacol., 2008, 74(5), 1476-1484. [http://dx. doi.org/10.1124/mol.108.047670] [PMID: 18728100]

[145] Moon, J.Y.; Song, S.; Yoon, S.Y.; Roh, D.H.; Kang, S.Y.; Park, J.H.; Beitz, A.J.; Lee, J.H. The differential effect of intrathecal Nav1.8 blockers on the induction and maintenance of capsaicinand peripheral ischemia-induced mechanical allodynia and thermal hyperalgesia. Anesth. Analg., 2012, 114(1), 215-223. [http://dx.doi. org/10.1213/ANE.0b013e318238002e] [PMID: 22127815]

[146] Iwamoto, T.; Takasugi, Y.; Higashino, H.; Ito, H.; Koga, Y.; Nakao, S. Antinociceptive action of carbamazepine on thermal hypersensitive pain at spinal level in a rat model of adjuvantinduced chronic inflammation. J. Anesth., 2011, 25(1), 78-86. [http://dx.doi.org/10.1007/s00540-010-1046-7] [PMID: 21113631]

[147] Tan, A.M.; Samad, O.A.; Dib-Hajj, S.D.; Waxman, S.G. Virusmediated knockdown of Nav1.3 in dorsal root ganglia of STZinduced diabetic rats alleviates tactile allodynia. Mol. Med., 2015, 21, 544-552. [http://dx.doi.org/10.2119/molmed.2015.00063] [PMID: 26101954]

[148] Pan, J.; Lin, X.J.; Ling, Z.H.; Cai, Y.Z. Effect of down-regulation of voltage-gated sodium channel Nav1.7 on activation of astrocytes and microglia in DRG in rats with cancer pain. Asian Pac. J. Trop. Med., 2015, 8(5), 405-411. [http://dx.doi.org/10.1016/S19957645(14)60352-7] [PMID: 26003602]

[149] Yin, R.; Liu, D.; Chhoa, M.; Li, C.M.; Luo, Y.; Zhang, M.; Lehto, S.G.; Immke, D.C.; Moyer, B.D. Voltage-gated sodium channel function and expression in injured and uninjured rat dorsal root ganglia neurons. Int. J. Neurosci., 2015. [PMID: 25562420]

[150] Roberson, D.P.; Binshtok, A.M.; Blasl, F.; Bean, B.P.; Woolf, C.J. Targeting of sodium channel blockers into nociceptors to produce long-duration analgesia: a systematic study and review. $\mathrm{Br} . \mathrm{J}$. Pharmacol., 2011, 164(1), 48-58. [http://dx.doi.org/10.1111/j. 1476-5381.2011.01391.x] [PMID: 21457220]

[151] Schwarz, S.K.; Cheung, H.M.; Ries, C.R.; Lee, S.M.; Wang, J.T.; MacLeod, B.A. Lumbar intrathecal administration of the quaternary lidocaine derivative, QX-314, produces irritation and death in mice. Anesthesiology, 2010, 113(2), 438-444. [http://dx. doi.org/10.1097/ALN.0b013e3181dfd31b] [PMID: 20613478]

[152] Takeda, M.; Tsuboi, Y.; Kitagawa, J.; Nakagawa, K.; Iwata, K.; Matsumoto, S. Potassium channels as a potential therapeutic target for trigeminal neuropathic and inflammatory pain. Mol. Pain, 2011, 7, 5. [http://dx.doi.org/10.1186/1744-8069-7-5] [PMID: 21219657]

[153] Du, X.; Gamper, N. Potassium channels in peripheral pain pathways: expression, function and therapeutic potential. Curr. Neuropharmacol., 2013, 11(6), 621-640. [http://dx.doi.org/10.2174/ 1570159X113119990042] [PMID: 24396338]
[154] Tsantoulas, C.; McMahon, S.B. Opening paths to novel analgesics: the role of potassium channels in chronic pain. Trends Neurosci., 2014, 37(3), 146-158. [http://dx.doi.org/10.1016/j.tins.2013.12.002] [PMID: 24461875]

[155] Olivera, B.M.; Miljanich, G.P.; Ramachandran, J.; Adams, M.E. Calcium channel diversity and neurotransmitter release: the omegaconotoxins and omega-agatoxins. Annu. Rev. Biochem., 1994, 63, 823-867. [http://dx.doi.org/10.1146/annurev.bi.63.070194.004135] [PMID: 7979255]

[156] Chaplan, S.R.; Pogrel, J.W.; Yaksh, T.L. Role of voltagedependent calcium channel subtypes in experimental tactile allodynia. J. Pharmacol. Exp. Ther., 1994, 269(3), 1117-1123. [PMID: 8014856]

[157] Malmberg, A.B.; Yaksh, T.L. Voltage-sensitive calcium channels in spinal nociceptive processing: blockade of $\mathrm{N}$ - and P-type channels inhibits formalin-induced nociception. J. Neurosci., 1994, 14(8), 4882-4890. [PMID: 8046458]

[158] Scott, D.A.; Wright, C.E.; Angus, J.A. Actions of intrathecal omega-conotoxins CVID, GVIA, MVIIA, and morphine in acute and neuropathic pain in the rat. Eur. J. Pharmacol., 2002, 451(3), 279-286. [http://dx.doi.org/10.1016/S0014-2999(02)02247-1] [PMID: 12242089]

[159] Snutch, T.P. Targeting chronic and neuropathic pain: the N-type calcium channel comes of age. NeuroRx: J. Am. Soc. Exper. NeuroTherapeutics, 2005, 2(4), 662-670.

[160] Adams, D.J.; Callaghan, B.; Berecki, G. Analgesic conotoxins: block and $\mathrm{G}$ protein-coupled receptor modulation of $\mathrm{N}$-type $(\mathrm{Ca}(\mathrm{V})$ 2.2) calcium channels. Br. J. Pharmacol., 2012, 166(2), 486-500. [http://dx.doi.org/10.1111/j.1476-5381.2011.01781.x] [PMID: 22091786]

[161] Murali, S.S.; Napier, I.A.; Mohammadi, S.A.; Alewood, P.F.; Lewis, R.J.; Christie, M.J. High-voltage-activated calcium current subtypes in mouse DRG neurons adapt in a subpopulation-specific manner after nerve injury. $J$. Neurophysiol., 2015, 113(5), 1511-1519. [http://dx.doi.org/10.1152/jn.00608.2014] [PMID: 25505111]

[162] Schroeder, C.I.; Doering, C.J.; Zamponi, G.W.; Lewis, R.J. N-type calcium channel blockers: novel therapeutics for the treatment of pain. Med. Chem., 2006, 2(5), 535-543. [http://dx.doi.org/10.2174/ 157340606778250216] [PMID: 17017994]

[163] Malmberg, A.B.; Yaksh, T.L. Effect of continuous intrathecal infusion of omega-conopeptides, N-type calcium-channel blockers, on behavior and antinociception in the formalin and hot-plate tests in rats. Pain, 1995, 60(1), 83-90. [http://dx.doi.org/10.1016/03043959(94)00094-U] [PMID: 7715945]

[164] Hama, A.; Sagen, J. Antinociceptive effects of the marine snail peptides conantokin-G and conotoxin MVIIA alone and in combination in rat models of pain. Neuropharmacology, 2009, 56(2), 556-563. [http://dx.doi.org/10.1016/j.neuropharm.2008.10. 008] [PMID: 19010337]

[165] Chen, S.R.; Wess, J.; Pan, H.L. Functional activity of the M2 and M4 receptor subtypes in the spinal cord studied with muscarinic acetylcholine receptor knockout mice. J. Pharmacol. Exp. Ther., 2005, 313(2), 765-770. [http://dx.doi.org/10.1124/jpet.104.082537] [PMID: 15665136]

[166] Skov, M.J.; Beck, J.C.; de Kater, A.W.; Shopp, G.M. Nonclinical safety of ziconotide: an intrathecal analgesic of a new pharmaceutical class. Int. J. Toxicol., 2007, 26(5), 411-421. [http://dx.doi.org/ 10.1080/10915810701582970] [PMID: 17963128]

[167] Chu, Y.X.; Zhang, Y.; Zhang, Y.Q.; Zhao, Z.Q. Involvement of microglial P2X7 receptors and downstream signaling pathways in long-term potentiation of spinal nociceptive responses. Brain Behav. Immun., 2010, 24(7), 1176-1189. [http://dx.doi.org/10.1016/ j.bbi.2010.06.001] [PMID: 20554014]

[168] Feldman, P.; Khanna, R. Challenging the catechism of therapeutics for chronic neuropathic pain: Targeting CaV2.2 interactions with CRMP2 peptides. Neurosci. Lett., 2013, 557 Pt A, 27-36.

[169] Bourinet, E.; Altier, C.; Hildebrand, M.E.; Trang, T.; Salter, M.W.; Zamponi, G.W. Calcium-permeable ion channels in pain signaling. Physiol. Rev., 2014, 94(1), 81-140. [http://dx.doi.org/10.1152/ physrev.00023.2013] [PMID: 24382884]

[170] Terashima, T.; Xu, Q.; Yamaguchi, S.; Yaksh, T.L. Intrathecal $\mathrm{P} / \mathrm{Q}-$ and R-type calcium channel blockade of spinal substance $\mathrm{P}$ release and c-Fos expression. Neuropharmacology, 2013, 75, 1-8. [http://dx.doi.org/10.1016/j.neuropharm.2013.06.018] [PMID: 23810829] 
[171] Cheng, J.K.; Lin, C.S.; Chen, C.C.; Yang, J.R.; Chiou, L.C. Effects of intrathecal injection of T-type calcium channel blockers in the rat formalin test. Behav. Pharmacol., 2007, 18(1), 1-8. [http://dx. doi.org/10.1097/FBP.0b013e3280141375] [PMID: 17218792]

[172] Takasusuki, T.; Yaksh, T.L. Regulation of spinal substance $p$ release by intrathecal calcium channel blockade. Anesthesiology, 2011, 115(1), 153-164. [http://dx.doi.org/10.1097/ALN.0b013 e31821950c2] [PMID: 21577088]

[173] Dalmolin, G.D.; Silva, C.R.; Rigo, F.K.; Gomes, G.M.; Cordeiro, Mdo.N.; Richardson, M.; Silva, M.A.; Prado, M.A.; Gomez, M.V.; Ferreira, J. Antinociceptive effect of Brazilian armed spider venom toxin Tx33 in animal models of neuropathic pain. Pain, 2011, 152(10), 2224-2232. [http://dx.doi.org/10.1016/j.pain.2011.04.015] [PMID: 21570770]

[174] Dogrul, A.; Gardell, L.R.; Ossipov, M.H.; Tulunay, F.C.; Lai, J.; Porreca, F. Reversal of experimental neuropathic pain by T-type calcium channel blockers. Pain, 2003, 105(1-2), 159-168. [http:// dx.doi.org/10.1016/S0304-3959(03)00177-5] [PMID: 14499432]

[175] Partridge, B.J.; Chaplan, S.R.; Sakamoto, E.; Yaksh, T.L. Characterization of the effects of gabapentin and 3-isobutylgamma-aminobutyric acid on substance P-induced thermal hyperalgesia. Anesthesiology, 1998, 88(1), 196-205. [http://dx.doi.org/ 10.1097/00000542-199801000-00028] [PMID: 9447873]

[176] Jun, J.H.; Yaksh, T.L. The effect of intrathecal gabapentin and 3isobutyl gamma-aminobutyric acid on the hyperalgesia observed after thermal injury in the rat. Anesth. Analg., 1998, 86(2), 348354. [PMID: 9459247]

[177] Chu, L.C.; Tsaur, M.L.; Lin, C.S.; Hung, Y.C.; Wang, T.Y.; Chen, C.C.; Cheng, J.K. Chronic intrathecal infusion of gabapentin prevents nerve ligation-induced pain in rats. Br. J. Anaesth., 2011, 106(5), 699-705. [http://dx.doi.org/10.1093/bja/aer063] [PMID: 21441243]

[178] Dong, L.; Crosby, N.D.; Winkelstein, B.A. Gabapentin alleviates facet-mediated pain in the rat through reduced neuronal hyperexcitability and astrocytic activation in the spinal cord. $J$. Pain, 2013, 14(12), 1564-1572. [http://dx.doi.org/10.1016/j.jpain. 2013.07.016] [PMID: 24094695]

[179] Rauck, R.; Coffey, R.J.; Schultz, D.M.; Wallace, M.S.; Webster, L.R.; McCarville, S.E.; Grigsby, E.J.; Page, L.M. Intrathecal gabapentin to treat chronic intractable noncancer pain. Anesthesiology, 2013, 119(3), 675-686. [http://dx.doi.org/10.1097/ALN.0b013e3182a10fbf] [PMID: 23835590]

[180] Sluka, K.A. Pain mechanisms involved in musculoskeletal disorders. J. Orthop. Sports Phys. Ther., 1996, 24(4), 240-254. [http://dx.doi. org/10.2519/jospt.1996.24.4.240] [PMID: 8892139]

[181] Zhou, H.Y.; Chen, S.R.; Pan, H.L. Targeting N-methyl-D-aspartate receptors for treatment of neuropathic pain. Expert Rev. Clin. Pharmacol., 2011, 4(3), 379-388. [http://dx.doi.org/10.1586/ecp. 11.17] [PMID: 21686074]

[182] Benrath, J.; Scharbert, G.; Gustorff, B.; Adams, H.A.; Kress, H.G. Long-term intrathecal $\mathrm{S}(+)$-ketamine in a patient with cancerrelated neuropathic pain. Br. J. Anaesth., 2005, 95(2), 247-249. [http://dx.doi.org/10.1093/bja/aei158] [PMID: 15951328]

[183] Glasgow, N.G.; Siegler Retchless, B.; Johnson, J.W. Molecular bases of NMDA receptor subtype-dependent properties. J. Physiol., 2015, 593(1), 83-95. [http://dx.doi.org/10.1113/jphysiol.2014.273763] [PMID: 25556790]

[184] Mendell, L.M. Physiological properties of unmyelinated fiber projection to the spinal cord. Exp. Neurol., 1966, 16(3), 316-332. [http://dx.doi.org/10.1016/0014-4886(66)90068-9] [PMID: 5928985]

[185] Davies, S.N.; Lodge, D. Evidence for involvement of Nmethylaspartate receptors in wind-up of class 2 neurones in the dorsal horn of the rat. Brain Res., 1987, 424(2), 402-406. [http://dx. doi.org/10.1016/0006-8993(87)91487-9] [PMID: 2823998]

[186] Dickenson, A.H.; Sullivan, A.F. Evidence for a role of the NMDA receptor in the frequency dependent potentiation of deep rat dorsal horn nociceptive neurones following $\mathrm{C}$ fibre stimulation. Neuropharmacology, 1987, 26(8), 1235-1238. [http://dx.doi.org/ 10.1016/0028-3908(87)90275-9] [PMID: 2821443]

[187] Price, T.J.; Ghosh, S. ZIPping to pain relief: the role (or not) of PKM $\zeta$ in chronic pain. Mol. Pain, 2013, 9, 6. [http://dx.doi.org/ 10.1186/1744-8069-9-6] [PMID: 23433248]

[188] Edelmayer, R.M.; Brederson, J.D.; Jarvis, M.F.; Bitner, R.S. Biochemical and pharmacological assessment of MAP-kinase signaling along pain pathways in experimental rodent models: a potential tool for the discovery of novel antinociceptive therapeutics. Biochem. Pharmacol., 2014, 87(3), 390-398. [http://dx.doi.org/ 10.1016/j.bcp.2013.11.019] [PMID: 24300134]

[189] Chahine, M.; OLeary, M.E. Regulation/modulation of sensory neuron sodium channels. Handbook Exp. Pharmacol., 2014, 221, 111-135. [http://dx.doi.org/10.1007/978-3-642-41588-3_6] [PMID: 24737234]

[190] Luo, X.Q.; Cai, Q.Y.; Chen, Y.; Guo, L.X.; Chen, A.Q.; Wu, Z.Q.; Lin, C. Tyrosine phosphorylation of the NR2B subunit of the NMDA receptor in the spinal cord contributes to chronic visceral pain in rats. Brain Res., 2014, 1542, 167-175. [http://dx.doi.org/ 10.1016/j.brainres.2013.10.008] [PMID: 24125810]

[191] Chaplan, S.R.; Malmberg, A.B.; Yaksh, T.L. Efficacy of spinal NMDA receptor antagonism in formalin hyperalgesia and nerve injury evoked allodynia in the rat. J. Pharmacol. Exp. Ther., 1997, 280(2), 829-838. [PMID: 9023297]

[192] Yamamoto, T.; Yaksh, T.L. Spinal pharmacology of thermal hyperesthesia induced by constriction injury of sciatic nerve. Excitatory amino acid antagonists. Pain, 1992, 49(1), 121-128. [http://dx.doi.org/10.1016/0304-3959(92)90198-K] [PMID: 1594273]

[193] Coderre, T.J. Potent analgesia induced in rats by combined action at PCP and polyamine recognition sites of the NMDA receptor complex. Eur. J. Neurosci., 1993, 5(4), 390-393. [http://dx.doi.org/ 10.1111/j.1460-9568.1993.tb00506.x] [PMID: 7903188]

[194] Coderre, T.J.; Vanempel, I. (Eaa) Antagonists as Analgesic Agents 2. Assessment of the Antinociceptive Activity of Combinations of Competitive and Noncompetitive NMDA Antagonists with Agents Acting at Allosteric-Glycine and Polyamine Receptor-Sites. Pain, 1994, 59(3), 353-359. [http://dx.doi.org/10.1016/0304-3959(94)900213] [PMID: 7708409]

[195] Rojas, A.C.; Alves, J.G.; Moreira, E.; Lima, R.; Esther Alencar Marques, M.; Moreira de Barros, G.A.; Fukushima, F.B.; Modolo, N.S.; Ganem, E.M. The effects of subarachnoid administration of preservative-free $\mathrm{S}(+)$-ketamine on spinal cord and meninges in dogs. Anesth. Analg., 2012, 114(2), 450-455. [http://dx.doi.org/ 10.1213/ANE.0b013e31823a5d1b] [PMID: 22167772]

[196] Walker, S.M.; Westin, B.D.; Deumens, R.; Grafe, M.; Yaksh, T.L. Effects of intrathecal ketamine in the neonatal rat: evaluation of apoptosis and long-term functional outcome. Anesthesiology, 2010, 113(1), 147-159. [http://dx.doi.org/10.1097/ALN.0b013e3181dcd71c] [PMID: 20526188]

[197] Vranken, J.H.; Troost, D.; de Haan, P.; Pennings, F.A.; van der Vegt, M.H.; Dijkgraaf, M.G.; Hollmann, M.W. Severe toxic damage to the rabbit spinal cord after intrathecal administration of preservative-free S(+)-ketamine. Anesthesiology, 2006, 105(4), 813-818. [http://dx.doi.org/10.1097/00000542-200610000-00028] [PMID: 17006081]

[198] Yaksh, T.L.; Tozier, N.; Horais, K.A.; Malkmus, S.; Rathbun, M Lafranco, L.; Eisenach, J. Toxicology profile of N-methyl-Daspartate antagonists delivered by intrathecal infusion in the canine model. Anesthesiology, 2008, 108(5), 938-949. [http://dx.doi.org/ 10.1097/ALN.0b013e31816c902a] [PMID: 18431131]

[199] Hassenbusch, S.J.; Satterfield, W.C.; Gradert, T.L.; Binhazim, A.W.; Ahad, G.; Mokhtarzadeh, M.; Schapiro, S.J.; Payne, R. Preclinical toxicity study of intrathecal administration of the pain relievers dextrorphan, dextromethorphan, and memantine in the sheep model. Neuromodulation: J. Int. Soc., 1999, 2(4), 230-240.

[200] Paoletti, P. Molecular basis of NMDA receptor functional diversity. Eur. J. Neurosci., 2011, 33(8), 1351-1365. [http://dx.doi. org/10.1111/j.1460-9568.2011.07628.x] [PMID: 21395862]

[201] Santangelo, R.M.; Acker, T.M.; Zimmerman, S.S.; Katzman, B.M.; Strong, K.L.; Traynelis, S.F.; Liotta, D.C. Novel NMDA receptor modulators: an update. Expert Opin. Ther. Pat., 2012, 22(11), 1337-1352. [http://dx.doi.org/10.1517/13543776.2012.728587] [PMID: 23009122]

[202] Kim, Y.; Cho, H.Y.; Ahn, Y.J.; Kim, J.; Yoon, Y.W. Effect of NMDA NR2B antagonist on neuropathic pain in two spinal cord injury models. Pain, 2012, 153(5), 1022-1029. [http://dx.doi.org/ 10.1016/j.pain.2012.02.003] [PMID: 22424878]

[203] Pedersen, L.M.; Gjerstad, J. Spinal cord long-term potentiation is attenuated by the NMDA-2B receptor antagonist Ro 256981. Acto Physiol. (Oxf.), 2008, 192(3), 421-427. [http://dx.doi.org/10.1111/ j.1748-1716.2007.01756.x] [PMID: 17970830] 
[204] Malmberg, A.B.; Gilbert, H.; McCabe, R.T.; Basbaum, A.I. Powerful antinociceptive effects of the cone snail venom-derived subtype-selective NMDA receptor antagonists conantokins $\mathrm{G}$ and T. Pain, 2003, 101(1-2), 109-116. [http://dx.doi.org/10.1016/S03043959(02)00303-2] [PMID: 12507705]

[205] Kolhekar, R.; Meller, S.T.; Gebhart, G.F. N-methyl-D-aspartate receptor-mediated changes in thermal nociception: allosteric modulation at glycine and polyamine recognition sites. Neuroscience, 1994, 63(4), 925-936. [http://dx.doi.org/10.1016/03064522(94)90560-6] [PMID: 7535397]

[206] Wallace, M.S.; Lam, V.; Schettler, J. NGX426, an oral AMPAkainate antagonist, is effective in human capsaicin-induced pain and hyperalgesia. Pain Med., 2012, 13(12), 1601-1610. [http://dx. doi.org/10.1111/j.1526-4637.2012.01509.x] [PMID: 23110368]

[207] Takano, Y.; Sato, E.; Kaneko, T.; Sato, I. Antihyperalgesic effects of intrathecally administered magnesium sulfate in rats. Pain, 2000, 84(2-3), 175-179. [http://dx.doi.org/10.1016/S0304-3959(99)002079] [PMID: 10666522]

[208] Chanimov, M.; Cohen, M.L.; Grinspun, Y.; Herbert, M.; Reif, R.; Kaufman, I.; Bahar, M. Neurotoxicity after spinal anaesthesia induced by serial intrathecal injections of magnesium sulphate. An experimental study in a rat model. Anaesthesia, 1997, 52(3), 223-228. [http://dx.doi.org/10.1111/j.1365-2044.1997.034-az0057.x] [PMID: 9124662]

[209] Mebazaa, M.S.; Ouerghi, S.; Frikha, N.; Moncer, K.; Mestiri, T.; James, M.F.; Ben Ammar, M.S. Is magnesium sulfate by the intrathecal route efficient and safe? Ann. Fr. Anesth. Reanim., 2011, 30(1), 47-50. [http://dx.doi.org/10.1016/j.annfar.2010.12.005] [PMID: 21236623]

[210] Roberts, J.C.; Grocholski, B.M.; Kitto, K.F.; Fairbanks, C.A. Pharmacodynamic and pharmacokinetic studies of agmatine after spinal administration in the mouse. J. Pharmacol. Exp. Ther., 2005, 314(3), 1226-1233. [http://dx.doi.org/10.1124/jpet.105.086173] [PMID: 15933157]

[211] Tong, C.K.; MacDermott, A.B. Both $\mathrm{Ca}^{2+}$-permeable and impermeable AMPA receptors contribute to primary synaptic drive onto rat dorsal horn neurons. (vol 575, pg 133, 2006). J. Physiol., 2006, 575(2), 685-685.

[212] Jin, H.C.; Keller, A.J.; Jung, J.K.; Subieta, A.; Brennan, T.J. Epidural tezampanel, an AMPA/kainate receptor antagonist, produces postoperative analgesia in rats. Anesth. Analg., 2007, 105(4), 1152-1159. [http://dx.doi.org/10.1213/01.ane.0000281435. 58012.e3] [PMID: 17898404]

[213] Oshiro, M.; Hefferan, M.P.; Kakinohana, O.; Lukacova, N.; Sugahara, K.; Yaksh, T.L.; Marsala, M. Suppression of stretch reflex activity after spinal or systemic treatment with AMPA receptor antagonist NGX424 in rats with developed baclofen tolerance. Br. J. Pharmacol., 2010, 161(5), 976-985. [http://dx.doi.org/ 10.1111/j.1476-5381.2010.00954.x] [PMID: 20977450]

[214] Sang, C.N.; Hostetter, M.P.; Gracely, R.H.; Chappell, A.S.; Schoepp, D.D.; Lee, G.; Whitcup, S.; Caruso, R.; Max, M.B. AMPA/ kainate antagonist LY293558 reduces capsaicin-evoked hyperalgesia but not pain in normal skin in humans. Anesthesiology, 1998, 89(5), 1060-1067. [http://dx.doi.org/10.1097/00000542-199811000-00005] [PMID: 9821993]

[215] Sorkin, L.S.; Yaksh, T.L.; Doom, C.M. Mechanical allodynia in rats is blocked by a $\mathrm{Ca}^{2+}$ permeable AMPA receptor antagonist. Neuroreport, 1999, 10(17), 3523-3526. [http://dx.doi.org/10.1097/ 00001756-199911260-00011] [PMID: 10619637]

[216] Jones, T.L.; Sorkin, L.S. Calcium-permeable alpha-amino-3-hydroxy5-methyl-4-isoxazolepropionic acid/kainate receptors mediate development, but not maintenance, of secondary allodynia evoked by first-degree burn in the rat. J. Pharmacol. Exp. Ther., 2004, 310(1), 223-229. [http://dx.doi.org/10.1124/jpet.103.064741] [PMID: 15007101]

[217] Dirig, D.M.; Yaksh, T.L. Intrathecal baclofen and muscimol, but not midazolam, are antinociceptive using the rat-formalin model. $J$. Pharmacol. Exp. Ther., 1995, 275(1), 219-227. [PMID: 7562553]

[218] Nadeson, R.; Guo, Z.; Porter, V.; Gent, J.P.; Goodchild, C.S. gamma-Aminobutyric acidA receptors and spinally mediated antinociception in rats. J. Pharmacol. Exp. Ther., 1996, 278(2), 620-626. [PMID: 8768712]

[219] Hwang, J.H.; Yaksh, T.L. The effect of spinal GABA receptor agonists on tactile allodynia in a surgically-induced neuropathic pain model in the rat. Pain, 1997, 70(1), 15-22. [http://dx.doi.org/ 10.1016/S0304-3959(96)03249-6] [PMID: 9106805]
[220] Malan, T.P.; Mata, H.P.; Porreca, F. Spinal GABA(A) and GABA(B) receptor pharmacology in a rat model of neuropathic pain. Anesthesiology, 2002, 96(5), 1161-1167. [http://dx.doi.org/ 10.1097/00000542-200205000-00020] [PMID: 11981157]

[221] Gwak, Y.S.; Tan, H.Y.; Nam, T.S.; Paik, K.S.; Hulsebosch, C.E.; Leem, J.W. Activation of spinal GABA receptors attenuates chronic central neuropathic pain after spinal cord injury. J. Neurotrauma, 2006, 23(7), 1111-1124. [http://dx.doi.org/10.1089/neu. 2006.23.1111] [PMID: 16866624]

[222] Roberts, L.A.; Beyer, C.; Komisaruk, B.R. Nociceptive responses to altered GABAergic activity at the spinal cord. Life Sci., $\mathbf{1 9 8 6}$, 39(18), 1667-1674. [http://dx.doi.org/10.1016/0024-3205(86)901645] [PMID: 3022091]

[223] Di Lio, A.; Benke, D.; Besson, M.; Desmeules, J.; Daali, Y.; Wang, Z.J.; Edwankar, R.; Cook, J.M.; Zeilhofer, H.U. HZ166, a novel GABAA receptor subtype-selective benzodiazepine site ligand, is antihyperalgesic in mouse models of inflammatory and neuropathic pain. Neuropharmacology, 2011, 60(4), 626-632. [http://dx.doi.org/ 10.1016/j.neuropharm.2010.11.026] [PMID: 21145329]

[224] Reichl, S.; Augustin, M.; Zahn, P.K.; Pogatzki-Zahn, E.M. Peripheral and spinal GABAergic regulation of incisional pain in rats. Pain, 2012, 153(1), 129-141. [http://dx.doi.org/10.1016/j.pain.2011.09.028] [PMID: 22054599]

[225] Svensson, E.; Persson, J.; Fitzsimmons, B.; Yaksh, T.L. Intrathecal neurosteroids and a neurosteroid antagonist: effects on inflammation-evoked thermal hyperalgesia and tactile allodynia. Neurosci. Lett., 2013, 548, 27-32. [http://dx.doi.org/10.1016/ j.neulet.2013.05.027] [PMID: 23707652]

[226] Juif, P.E.; Melchior, M.; Poisbeau, P. Characterization of the fast GABAergic inhibitory action of etifoxine during spinal nociceptive processing in male rats. Neuropharmacology, 2015, 91, 117-122. [http://dx.doi.org/10.1016/j.neuropharm.2014.12.022] [PMID: 25545681]

[227] Whitwam, J.G.; Niv, D.; Loh, L.; Jack, R.D. Depression of nociceptive reflexes by intrathecal benzodiazepine in dogs. Lancet, 1982, 2(8313), 1465. [http://dx.doi.org/10.1016/S0140-6736(82) 91368-X] [PMID: 6129540]

[228] Serrao, J.M.; Marks, R.L.; Morley, S.J.; Goodchild, C.S. Intrathecal midazolam for the treatment of chronic mechanical low back pain: a controlled comparison with epidural steroid in a pilot study. Pain, 1992, 48(1), 5-12. [http://dx.doi.org/10.1016/0304-3959(92)90125U] [PMID: 1531383]

[229] Tucker, A.P.; Lai, C.; Nadeson, R.; Goodchild, C.S. Intrathecal midazolam I: a cohort study investigating safety. Anesth. Analg., 2004, 98(6), 1512-1520. [http://dx.doi.org/10.1213/01.ANE.0000087075. 14589.F5] [PMID: 15155299]

[230] Tucker, A.P.; Mezzatesta, J.; Nadeson, R.; Goodchild, C.S. Intrathecal midazolam II: combination with intrathecal fentanyl for labor pain. Anesth. Analg., 2004, 98(6), 1521-1527. [table of contents.]. [http://dx.doi.org/10.1213/01.ANE.0000112434.68702.E4] [PMID: 15155300]

[231] Ho, K.M.; Ismail, H. Use of intrathecal midazolam to improve perioperative analgesia: a meta-analysis. Anaesth. Intens. Care, 2008, 36(3), 365-373. [PMID: 18564797]

[232] Olsen, R.W.; Sieghart, W. International Union of Pharmacology. LXX. Subtypes of $\gamma$-aminobutyric acid(A) receptors: classification on the basis of subunit composition, pharmacology, and function. Update. Pharmacol. Rev., 2008, 60(3), 243-260. [http://dx.doi. org/10.1124/pr.108.00505] [PMID: 18790874]

[233] Sieghart, W.; Ramerstorfer, J.; Sarto-Jackson, I.; Varagic, Z.; Ernst, M. A novel GABA(A) receptor pharmacology: drugs interacting with the $\alpha(+) \beta(-)$ interface. Br. J. Pharmacol., 2012, $166(2)$, 476485. [http://dx.doi.org/10.1111/j.1476-5381.2011.01779.x] [PMID: 22074382]

[234] Sigel, E.; Lüscher, B.P. A closer look at the high affinity benzodiazepine binding site on GABAA receptors. Curr. Top. Med. Chem., 2011, 11(2), 241-246. [http://dx.doi.org/10.2174/ 156802611794863562] [PMID: 21189125]

[235] Wang, M. Neurosteroids and GABA-A Receptor Function. Front. Endocrinol. (Lausanne), 2011, 2, 44. [http://dx.doi.org/10.3389/ fendo.2011.00044] [PMID: 22654809]

[236] Carver, C.M.; Reddy, D.S. Neurosteroid interactions with synaptic and extrasynaptic GABA(A) receptors: regulation of subunit plasticity, phasic and tonic inhibition, and neuronal network 
excitability. Psychopharmacology (Berl.), 2013, 230(2), 151-188. [http://dx.doi.org/10.1007/s00213-013-3276-5] [PMID: 24071826]

[237] Bohlhalter, S.; Weinmann, O.; Mohler, H.; Fritschy, J.M. Laminar compartmentalization of GABAA-receptor subtypes in the spinal cord: an immunohistochemical study. J. Neurosci., 1996, 16(1), 283-297. [PMID: 8613794]

[238] Enna, S.J.; McCarson, K.E. The role of GABA in the mediation and perception of pain. Adv. Pharmacol., 2006, 54, 1-27. [http:// dx.doi.org/10.1016/S1054-3589(06)54001-3] [PMID: 17175808]

[239] Labrakakis, C.; Tong, C.K.; Weissman, T.; Torsney, C.; MacDermott, A.B. Localization and function of ATP and GABAA receptors expressed by nociceptors and other postnatal sensory neurons in rat. J. Physiol., 2003, 549(Pt 1), 131-142. [http://dx.doi. org/10.1113/jphysiol.2002.031963] [PMID: 12665615]

[240] Witschi, R.; Punnakkal, P.; Paul, J.; Walczak, J.S.; Cervero, F.; Fritschy, J.M.; Kuner, R.; Keist, R.; Rudolph, U.; Zeilhofer, H.U. Presynaptic alpha2-GABAA receptors in primary afferent depolarization and spinal pain control. J. Neurosci., 2011, 31(22), 8134-8142. [http://dx.doi.org/10.1523/JNEUROSCI.6328-10.2011] [PMID: 21632935]

[241] Hevers, W.; Lüddens, H. The diversity of GABAA receptors. Pharmacological and electrophysiological properties of GABAA channel subtypes. Mol. Neurobiol., 1998, 18(1), 35-86. [http://dx. doi.org/10.1007/BF02741459] [PMID: 9824848]

[242] Krall, J.; Balle, T.; Krogsgaard-Larsen, N.; Sørensen, T.E.; Krogsgaard-Larsen, P.; Kristiansen, U.; Frølund, B. GABAA receptor partial agonists and antagonists: structure, binding mode, and pharmacology. Adv. Pharmacol., 2015, 72, 201-227. [http:// dx.doi.org/10.1016/bs.apha.2014.10.003] [PMID: 25600372]

[243] Yaksh, T.L.; Allen, J.W. The use of intrathecal midazolam in humans: a case study of process. Anesth. Analg., 2004, 98(6), 1536-1545. [http://dx.doi.org/10.1213/01.ANE.0000122638.41130.BF] [PMID: 15155302]

[244] Yaksh, T.L.; Allen, J.W. Preclinical insights into the implementation of intrathecal midazolam: a cautionary tale. Anesth. Analg., 2004, 98(6), 1509-1511. [http://dx.doi.org/10.1213/01.ANE.0000121768. 79904.7F] [PMID: 15155298]

[245] Malinovsky, J.M.; Cozian, A.; Lepage, J.Y.; Mussini, J.M.; Pinaud, M.; Souron, R. Ketamine and midazolam neurotoxicity in the rabbit. Anesthesiology, 1991, 75(1), 91-97. [http://dx.doi.org/10. 1097/00000542-199107000-00015] [PMID: 2064066]

[246] Erdine, S.; Yücel, A.; Ozyalçin, S.; Ozyuvaci, E.; Talu, G.K.; Ahiskali, B.; Apak, H.; Savci, N. Neurotoxicity of midazolam in the rabbit. Pain, 1999, 80(1-2), 419-423. [http://dx.doi.org/10.1016/ S0304-3959(98)00240-1] [PMID: 10204757]

[247] Abedini, M.; Parish, M.; Mahmoodpoor, A.; Vazifehshenas, H. Cauda equina syndrome as a result of inadvertent intrathecal injection of sodium thiopentone. Anaesth. Intens. Care, 2015, 43(1), 131-132. [PMID: 25579301]

[248] Wafford, K.A.; van Niel, M.B.; Ma, Q.P.; Horridge, E.; Herd, M.B.; Peden, D.R.; Belelli, D.; Lambert, J.J. Novel compounds selectively enhance delta subunit containing GABA A receptors and increase tonic currents in thalamus. Neuropharmacology, 2009, 56(1), 182-189. [http://dx.doi.org/10.1016/j.neuropharm.2008.08. 004] [PMID: 18762200]

[249] Ferando, I.; Mody, I. Interneuronal GABAA receptors inside and outside of synapses. Curr. Opin. Neurobiol., 2014, 26, 57-63. [http://dx.doi.org/10.1016/j.conb.2013.12.001] [PMID: 24650505]

[250] Petersen, J.G.; Bergmann, R.; Krogsgaard-Larsen, P.; Balle, T.; Frølund, B. Probing the orthosteric binding site of GABAA receptors with heterocyclic GABA carboxylic acid bioisosteres. Neurochem. Res., 2014, 39(6), 1005-1015. [http://dx.doi.org/10. 1007/s11064-013-1226-6] [PMID: 24362592]

[251] Aouad, M.; Petit-Demoulière, N.; Goumon, Y.; Poisbeau, P. Etifoxine stimulates allopregnanolone synthesis in the spinal cord to produce analgesia in experimental mononeuropathy. Eur. J. Pain, 2014, 18(2), 258-268. [http://dx.doi.org/10.1002/j.15322149.2013.00367.x] [PMID: 23881562]

[252] Hoestgaard-Jensen, K.; Dalby, N.O.; Krall, J.; Hammer, H.; Krogsgaard-Larsen, P.; Frølund, B.; Jensen, A.A. Probing $\alpha 4 \beta \delta$ GABAA receptor heterogeneity: differential regional effects of a functionally selective $\alpha 4 \beta 1 \delta / \alpha 4 \beta 3 \delta$ receptor agonist on tonic and phasic inhibition in rat brain. J. Neurosci, 2014, 34 (49), 16256-16272. [http://dx.doi.org/10.1523/JNEUROSCI.149514.2014] [PMID: 25471566]
[253] Wilson, P.R.; Yaksh, T.L. Baclofen is antinociceptive in the spinal intrathecal space of animals. Eur. J. Pharmacol., 1978, 51(4), 323330. [http://dx.doi.org/10.1016/0014-2999(78)90423-5] [PMID: 581376]

[254] Mathur, S.N.; Chu, S.K.; McCormick, Z.; Chang Chien, G.C.; Marciniak, C.M. Long-term intrathecal baclofen: outcomes after more than 10 years of treatment. $P M R, \mathbf{2 0 1 4}, 6(6), 506-513 . e 1$. [http://dx.doi.org/10.1016/j.pmrj.2013.12.005] [PMID: 24355547]

[255] Guillaume, D.; Van Havenbergh, A.; Vloeberghs, M.; Vidal, J.; Roeste, G. A clinical study of intrathecal baclofen using a programmable pump for intractable spasticity. Arch. Phys. Med. Rehabil., 2005, 86(11), 2165-2171. [http://dx.doi.org/10.1016/j. apmr.2005.05.018] [PMID: 16271565]

[256] Furr-Stimming, E.; Boyle, A.M.; Schiess, M.C. Spasticity and intrathecal baclofen. Semin. Neurol., 2014, 34(5), 591-596. [http:// dx.doi.org/10.1055/s-0034-1396012] [PMID: 25520030]

[257] Patel, S.; Naeem, S.; Kesingland, A.; Froestl, W.; Capogna, M.; Urban, L.; Fox, A. The effects of GABA(B) agonists and gabapentin on mechanical hyperalgesia in models of neuropathic and inflammatory pain in the rat. Pain, 2001, 90(3), 217-226. [http:// dx.doi.org/10.1016/S0304-3959(00)00404-8] [PMID: 11207393]

[258] Hama, A.; Sagen, J. Combinations of intrathecal gamma-aminobutyrate receptor agonists and N-methyl-d-aspartate receptor antagonists in rats with neuropathic spinal cord injury pain. Eur. $J$. Pharmacol., 2012, 683(1-3), 101-108. [http://dx.doi.org/10.1016/ j.ejphar.2012.03.015] [PMID: 22449374]

[259] Liu, P.; Guo, W.Y.; Zhao, X.N.; Bai, H.P.; Wang, Q.; Wang, X.L.; Zhang, Y.Z. Intrathecal baclofen, a GABAB receptor agonist, inhibits the expression of p-CREB and NR2B in the spinal dorsal horn in rats with diabetic neuropathic pain. Can. J. Physiol. Pharmacol., 2014, 92(8), 655-660. [http://dx.doi.org/10.1139/cjpp2013-0463] [PMID: 24988216]

[260] van Rijn, M.A.; Munts, A.G.; Marinus, J.; Voormolen, J.H.; de Boer, K.S.; Teepe-Twiss, I.M.; van Dasselaar, N.T.; Delhaas, E.M.; van Hilten, J.J. Intrathecal baclofen for dystonia of complex regional pain syndrome. Pain, 2009, 143(1-2), 41-47. [http://dx.doi.org/10. 1016/j.pain.2009.01.014] [PMID: 19232828]

[261] Brown, D.C.; Agnello, K. Intrathecal substance P-saporin in the dog: efficacy in bone cancer pain. Anesthesiology, 2013, 119(5), 1178-1185. [http://dx.doi.org/10.1097/ALN.0b013e3182a95188] [PMID: 24195949]

[262] Kornau, H.C. GABA(B) receptors and synaptic modulation. Cell Tissue Res., 2006, 326(2), 517-533. [http://dx.doi.org/10.1007/ s00441-006-0264-7] [PMID: 16932937]

[263] Yang, K.; Wang, D.; Li, Y.Q. Distribution and depression of the GABA(B) receptor in the spinal dorsal horn of adult rat. Brain Res. Bull., 2001, 55(4), 479-485. [http://dx.doi.org/10.1016/S0361-9230 (01)00546-9] [PMID: 11543948]

[264] Thomas, D.A.; Navarrete, I.M.; Graham, B.A.; McGowan, M.K.; Hammond, D.L. Antinociception produced by systemic R(+)baclofen hydrochloride is attenuated by CGP 35348 administered to the spinal cord or ventromedial medulla of rats. Brain Res. 1996, 718(1-2), 129-137. [http://dx.doi.org/10.1016/0006-8993(96) 00100-X] [PMID: 8773775]

[265] Aran, S.; Hammond, D.L. Antagonism of baclofen-induced antinociception by intrathecal administration of phaclofen or 2 hydroxy-saclofen, but not delta-aminovaleric acid in the rat. $J$. Pharmacol. Exp. Ther., 1991, 257(1), 360-368. [PMID: 1850472]

[266] Sabbe, M.B.; Grafe, M.R.; Pfeifer, B.L.; Mirzai, T.H.; Yaksh, T.L. Toxicology of baclofen continuously infused into the spinal intrathecal space of the dog. Neurotoxicology, 1993, 14(4), 397410. [PMID: 8164885]

[267] Deer, T.R.; Raso, L.J.; Coffey, R.J.; Allen, J.W. Intrathecal baclofen and catheter tip inflammatory mass lesions (granulomas): a reevaluation of case reports and imaging findings in light of experimental, clinicopathological, and radiological evidence. Pain Med., 2008, 9(4), 391-395. [http://dx.doi.org/10.1111/j.1526-4637. 2008.00468.x] [PMID: 18489628]

[268] Murphy, P.M.; Skouvaklis, D.E.; Amadeo, R.J.; Haberman, C.; Brazier, D.H.; Cousins, M.J. Intrathecal catheter granuloma associated with isolated baclofen infusion. Anesth. Analg., 2006, 102(3), 848852. [http://dx.doi.org/10.1213/01.ane.0000196523.06573.10] [PMID: 16492839]

[269] Enna, S.J.; Harstad, E.B.; McCarson, K.E. Regulation of neurokinin-1 receptor expression by GABA(B) receptor agonists. 
Life Sci., 1998, 62(17-18), 1525-1530. [http://dx.doi.org/10.1016/ S0024-3205(98)00101-5] [PMID: 9585130]

[270] Brusberg, M.; Ravnefjord, A.; Martinsson, R.; Larsson, H.; Martinez, V.; Lindström, E. The GABA(B) receptor agonist, baclofen, and the positive allosteric modulator, CGP7930, inhibit visceral pain-related responses to colorectal distension in rats. Neuropharmacology, 2009, 56(2), 362-367. [http://dx.doi.org/ 10.1016/j.neuropharm.2008.09.006] [PMID: 18824012]

[271] Prado, W. A.; Goncalves, A. S. Antinociceptive effect of intrathecal neostigmine evaluated in rats by two different pain models. Braz. J. Med. Biol. Res., 1997, 30(10), 1225-1231.

[272] Hwang, J.H.; Hwang, K.S.; Leem, J.K.; Park, P.H.; Han, S.M.; Lee, D.M. The antiallodynic effects of intrathecal cholinesterase inhibitors in a rat model of neuropathic pain. Anesthesiology, 1999, 90(2), 492-499. [http://dx.doi.org/10.1097/00000542-19990200000025] [PMID: 9952157]

[273] Hartvig, P.; Gillberg, P.G.; Gordh, T., Jr; Post, C. Cholinergic mechanisms in pain and analgesia. Trends Pharmacol. Sci., 1989(Suppl.), 75-79. [PMID: 2694528]

[274] Lavandhomme, P.; Pan, H.L.; Eisenach, J.C. Intrathecal neostigmine, but not sympathectomy, relieves mechanical allodynia in a rat model of neuropathic pain. Anesthesiology, 1998, 89(2), 493499. [http://dx.doi.org/10.1097/00000542-199808000-00027] [PMID: 9710409]

[275] Park, P.; Schachter, S.; Yaksh, T. Intrathecal huperzine A increases thermal escape latency and decreases flinching behavior in the formalin test in rats. Neurosci. Lett., 2010, 470(1), 6-9. [http:// dx.doi.org/10.1016/j.neulet.2009.12.033] [PMID: 20026382]

[276] Bouaziz, H.; Tong, C.; Eisenach, J.C. Postoperative analgesia from intrathecal neostigmine in sheep. Anesth. Analg., 1995, 80(6), 11401144. [PMID: 7762841]

[277] Lauretti, G.R.; Hood, D.D.; Eisenach, J.C.; Pfeifer, B.L. A multicenter study of intrathecal neostigmine for analgesia following vaginal hysterectomy. Anesthesiology, 1998, 89(4), 913-918. [http:// dx.doi.org/10.1097/00000542-199810000-00016] [PMID: 9778009]

[278] Ho, K.M.; Ismail, H.; Lee, K.C.; Branch, R. Use of intrathecal neostigmine as an adjunct to other spinal medications in perioperative and peripartum analgesia: a meta-analysis. Anaesth. Intens. Care, 2005, 33(1), 41-53. [PMID: 15957690]

[279] Habib, A.S.; Gan, T.J. Use of neostigmine in the management of acute postoperative pain and labour pain: a review. CNS Drugs, 2006, 20(10), 821-839. [http://dx.doi.org/10.2165/00023210-20062010000004] [PMID: 16999453]

[280] Naguib, M.; Yaksh, T.L. Characterization of muscarinic receptor subtypes that mediate antinociception in the rat spinal cord. Anesth. Analg., 1997, 85(4), 847-853. [http://dx.doi.org/10.1213/00000539199710000-00025] [PMID: 9322468]

[281] Iwamoto, E.T.; Marion, L. Characterization of the antinociception produced by intrathecally administered muscarinic agonists in rats. $J$. Pharmacol. Exp. Ther., 1993, 266(1), 329-338. [PMID: 8101218]

[282] Yamamura, H.I.; Wamsley, J.K.; Deshmukh, P.; Roeske, W.R. Differential light microscopic autoradiographic localization of muscarinic cholinergic receptors in the brainstem and spinal cord of the rat using [3H]pirenzepine. Eur. J. Pharmacol., 1983, 91(1), 147-149. [http://dx.doi.org/10.1016/0014-2999(83)90379-5] [PMID: 6688587]

[283] Bonner, T.I. New subtypes of muscarinic acetylcholine receptors. Trends Pharmacol. Sci., 1989(Suppl.), 11-15. [PMID: 2694516]

[284] Caulfield, M.P.; Birdsall, N.J. International Union of Pharmacology. XVII. Classification of muscarinic acetylcholine receptors. Pharmacol. Rev., 1998, 50(2), 279-290. [PMID: 9647869]

[285] Halliwell, J.V. Physiological mechanisms of cholinergic action in the hippocampus. Prog. Brain Res., 1990, 84, 255-272. [http://dx. doi.org/10.1016/S0079-6123(08)60910-3] [PMID: 2176300]

[286] Fisahn, A.; Yamada, M.; Duttaroy, A.; Gan, J.W.; Deng, C.X.; McBain, C.J.; Wess, J. Muscarinic induction of hippocampal gamma oscillations requires coupling of the M1 receptor to two mixed cation currents. Neuron, 2002, 33(4), 615-624. [http:// dx.doi.org/10.1016/S0896-6273(02)00587-1] [PMID: 11856534]

[287] Brown, D.A. Muscarinic acetylcholine receptors (mAChRs) in the nervous system: some functions and mechanisms. J. Mol. Neurosci., 2010, 41(3), 340-346. [http://dx.doi.org/10.1007/s12031010-9377-2] [PMID: 20446119]

[288] Cai, Y-Q.; Chen, S-R.; Han, H-D.; Sood, A.K.; Lopez-Berestein, G.; Pan, H-L. Role of M2, M3, and M4 muscarinic receptor subtypes in the spinal cholinergic control of nociception revealed using siRNA in rats. J. Neurochem., 2009, 111(4), 10001010. [http://dx.doi.org/10.1111/j.1471-4159.2009.06396.x] [PMID: 19780895]

[289] Chen, S.R.; Chen, H.; Yuan, W.X.; Wess, J.; Pan, H.L. Differential regulation of primary afferent input to spinal cord by muscarinic receptor subtypes delineated using knockout mice. J. Biol. Chem., 2014, 289(20), 14321-14330. [http://dx.doi.org/10.1074/jbc.M114. 550384] [PMID: 24695732]

[290] Zhang, H.M.; Zhou, H.Y.; Chen, S.R.; Gautam, D.; Wess, J.; Pan, H.L. Control of glycinergic input to spinal dorsal horn neurons by distinct muscarinic receptor subtypes revealed using knockout mice. J. Pharmacol. Exp. Ther., 2007, 323(3), 963-971. [http://dx.doi. org/10.1124/jpet.107.127795] [PMID: 17878406]

[291] Baba, H.; Kohno, T.; Okamoto, M.; Goldstein, P.A.; Shimoji, K.; Yoshimura, M. Muscarinic facilitation of GABA release in substantia gelatinosa of the rat spinal dorsal horn. J. Physiol., 1998, 508(Pt 1), 83-93. [http://dx.doi.org/10.1111/j.1469-7793.1998.083br. x] [PMID: 9490821]

[292] Yaksh, T.L.; Grafe, M.R.; Malkmus, S.; Rathbun, M.L.; Eisenach, J.C. Studies on the safety of chronically administered intrathecal neostigmine methylsulfate in rats and dogs. Anesthesiology, 1995, 82(2), 412-427. [http://dx.doi.org/10.1097/00000542-19950200000012] [PMID: 7856900]

[293] Greig, N.H.; Reale, M.; Tata, A.M. New pharmacological approaches to the cholinergic system: an overview on muscarinic receptor ligands and cholinesterase inhibitors. Recent Patents CNS Drug Discov., 2013, 8(2), 123-141. [http://dx.doi.org/10.2174/ 1574889811308020003] [PMID: 23597304]

[294] Sosnowski, M.; Stevens, C.W.; Yaksh, T.L. Assessment of the role of A1/A2 adenosine receptors mediating the purine antinociception, motor and autonomic function in the rat spinal cord. J. Pharmacol. Exp. Ther., 1989, 250(3), 915-922. [PMID: 2778719]

[295] Lee, Y.W.; Yaksh, T.L. Pharmacology of the spinal adenosine receptor which mediates the antiallodynic action of intrathecal adenosine agonists. J. Pharmacol. Exp. Ther., 1996, 277(3), 16421648. [PMID: 8667233]

[296] Cui, J.G.; Sollevi, A.; Linderoth, B.; Meyerson, B.A. Adenosine receptor activation suppresses tactile hypersensitivity and potentiates spinal cord stimulation in mononeuropathic rats. Neurosci. Lett., 1997, 223(3), 173-176. [http://dx.doi.org/10.1016/S0304-3940(97) 13435-8] [PMID: 9080460]

[297] Yamaguchi, D.; Terayama, R.; Omura, S.; Tsuchiya, H.; Sato, T.; Ichikawa, H.; Sugimoto, T. Effect of adenosine A1 receptor agonist on the enhanced excitability of spinal dorsal horn neurons after peripheral nerve injury. Int. J. Neurosci., 2014, 124(3), 213-222. [http:// dx.doi.org/10.3109/00207454.2013.842566] [PMID: 24016034]

[298] Katz, N.K.; Ryals, J.M.; Wright, D.E. Central or peripheral delivery of an adenosine A1 receptor agonist improves mechanical allodynia in a mouse model of painful diabetic neuropathy. Neuroscience, 2015, 285, 312-323. [http://dx.doi.org/10.1016/j.neuroscience.2014. 10.065] [PMID: 25451280]

[299] Zahn, P.K.; Straub, H.; Wenk, M.; Pogatzki-Zahn, E.M. Adenosine A1 but not A2a receptor agonist reduces hyperalgesia caused by a surgical incision in rats: a pertussis toxin-sensitive $G$ proteindependent process. Anesthesiology, 2007, 107(5), 797-806. [http:// dx.doi.org/10.1097/01.anes.0000286982.36342.3f] [PMID: 18073555]

[300] Rane, K.; Karlsten, R.; Sollevi, A.; Gordh, T., Jr; Svensson, B.A. Spinal cord morphology after chronic intrathecal administration of adenosine in the rat. Acta Anaesthesiol. Scand., 1999, 43(10), 1035-1040. [http://dx.doi.org/10.1034/j.1399-6576.1999.431011.x] [PMID: 10593467]

[301] Eisenach, J.C.; Curry, R.; Hood, D.D. Dose response of intrathecal adenosine in experimental pain and allodynia. Anesthesiology, 2002, 97(4), 938-942. [http://dx.doi.org/10.1097/00000542-20021000000028] [PMID: 12357162]

[302] Belfrage, M.; Segerdahl, M.; Arnér, S.; Sollevi, A. The safety and efficacy of intrathecal adenosine in patients with chronic neuropathic pain. Anesth. Analg., 1999, 89(1), 136-142. [PMID: 10389791]

[303] Eisenach, J.C.; Rauck, R.L.; Curry, R. Intrathecal, but not intravenous adenosine reduces allodynia in patients with neuropathic pain. Pain, 2003, 105(1-2), 65-70. [http://dx.doi.org/10.1016/S03043959(03)00158-1] [PMID: 14499421] 
[304] Sharma, M.; Mohta, M.; Chawla, R. Efficacy of intrathecal adenosine for postoperative pain relief. Eur. J. Anaesthesiol., 2006, 23(6), 449-453. [http://dx.doi.org/10.1017/S0265021506000342] [PMID: 16507193]

[305] Fredholm, B.B.; IJzerman, A.P.; Jacobson, K.A.; Klotz, K.N.; Linden, J. International Union of Pharmacology. XXV. Nomenclature and classification of adenosine receptors. Pharmacol. Rev., 2001, 53(4), 527-552. [PMID: 11734617]

[306] Choca, J.I.; Green, R.D.; Proudfit, H.K. Adenosine A1 and A2 receptors of the substantia gelatinosa are located predominantly on intrinsic neurons: an autoradiography study. J. Pharmacol. Exp. Ther., 1988, 247(2), 757-764. [PMID: 3183969]

[307] Sawynok, J.; Liu, X.J. Adenosine in the spinal cord and periphery: release and regulation of pain. Prog. Neurobiol., 2003, 69(5), 313-340. [http://dx.doi.org/10.1016/S0301-0082(03)00050-9] [PMID: 12787573]

[308] Schulte, G.; Robertson, B.; Fredholm, B.B.; DeLander, G.E.; Shortland, P.; Molander, C. Distribution of antinociceptive adenosine A1 receptors in the spinal cord dorsal horn, and relationship to primary afferents and neuronal subpopulations. Neuroscience, 2003, 121(4), 907-916. [http://dx.doi.org/10.1016/S0306-4522(03) 00480-9] [PMID: 14580941]

[309] Sawynok, J. Adenosine receptor activation and nociception. Eur. J. Pharmacol., 1998, 347(1), 1-11. [http://dx.doi.org/10.1016/S00142999(97)01605-1] [PMID: 9650842]

[310] Li, J.; Perl, E.R. Adenosine inhibition of synaptic transmission in the substantia gelatinosa. J. Neurophysiol., 1994, 72(4), 1611-1621. [PMID: 7823090]

[311] Sosnowski, M.; Yaksh, T.L. The role of spinal and brainstem adenosine receptors in the modulation of the volume-evoked micturition reflex in the unanesthetized rat. Brain Res., 1990, 515 (1-2), 207-213. [http://dx.doi.org/10.1016/0006-8993(90)90597-5] [PMID: 2357559]

[312] Kitta, T.; Chancellor, M.B.; de Groat, W.C.; Kuno, S.; Nonomura, K.; Yoshimura, N. Suppression of bladder overactivity by adenosine A2A receptor antagonist in a rat model of Parkinson disease. $J$. Urol., 2012, 187(5), 1890-1897. [http://dx.doi.org/10.1016/j.juro. 2011.12.062] [PMID: 22425056]

[313] Martin, T.J.; Eisenach, J.C.; Misler, J.; Childers, S.R. Chronic activation of spinal adenosine A1 receptors results in hypersensitivity. Neuroreport, 2006, 17(15), 1619-1622. [http://dx.doi.org/10.1097/ 01.wnr.0000239949.37825.e9] [PMID: 17001280]

[314] Chiari, A.; Yaksh, T.L.; Myers, R.R.; Provencher, J.; Moore, L.; Lee, C.S.; Eisenach, J.C. Preclinical toxicity screening of intrathecal adenosine in rats and dogs. Anesthesiology, 1999, 91(3), 824-832. [http://dx.doi.org/10.1097/00000542-199909000-00035] [PMID: 10485794]

[315] Karlsten, R.; Gordh, T., Jr; Svensson, B.A. A neurotoxicologic evaluation of the spinal cord after chronic intrathecal injection of R-phenylisopropyl adenosine (R-PIA) in the rat. Anesth. Analg., 1993, 77(4), 731-736. [http://dx.doi.org/10.1213/00000539-19931000000013] [PMID: 8214657]

[316] Loram, L.C.; Harrison, J.A.; Sloane, E.M.; Hutchinson, M.R.; Sholar, P.; Taylor, F.R.; Berkelhammer, D.; Coats, B.D.; Poole, S.; Milligan, E.D.; Maier, S.F.; Rieger, J.; Watkins, L.R. Enduring reversal of neuropathic pain by a single intrathecal injection of adenosine $2 \mathrm{~A}$ receptor agonists: a novel therapy for neuropathic pain. J. Neurosci., 2009, 29(44), 14015-14025. [http://dx.doi.org/ 10.1523/JNEUROSCI.3447-09.2009] [PMID: 19890011]

[317] Dai, S.S.; Zhou, Y.G. Adenosine 2A receptor: a crucial neuromodulator with bidirectional effect in neuroinflammation and brain injury. Rev. Neurosci., 2011, 22(2), 231-239. [http://dx.doi.org/ 10.1515/rns.2011.020] [PMID: 21476942]

[318] Yaksh, T.L.; Dirig, D.M.; Conway, C.M.; Svensson, C.; Luo, Z.D.; Isakson, P.C. The acute antihyperalgesic action of nonsteroidal, anti-inflammatory drugs and release of spinal prostaglandin E2 is mediated by the inhibition of constitutive spinal cyclooxygenase- 2 (COX-2) but not COX-1. J. Neurosci., 2001, 21(16), 5847-5853. [PMID: 11487607]

[319] Malmberg, A.B.; Yaksh, T.L. Cyclooxygenase inhibition and the spinal release of prostaglandin E2 and amino acids evoked by paw formalin injection: a microdialysis study in unanesthetized rats. $J$. Neurosci., 1995, 15(4), 2768-2776. [PMID: 7722627]

[320] Yang, L.C.; Marsala, M.; Yaksh, T.L. Characterization of time course of spinal amino acids, citrulline and PGE2 release after carrageenan/kaolin-induced knee joint inflammation: a chronic microdialysis study. Pain, 1996, 67(2-3), 345-354. [http://dx.doi. org/10.1016/0304-3959(96)03106-5] [PMID: 8951928]

[321] Lau, Y.M.; Wong, S.C.; Tsang, S.W.; Lau, W.K.; Lu, A.P.; Zhang, H. Cellular sources of cyclooxygenase- 1 and -2 up-regulation in the spinal dorsal horn after spinal nerve ligation. Neuropathol. Appl. Neurobiol., 2014, 40(4), 452-463. [http://dx.doi.org/10.1111/nan. 12078] [PMID: 23899306]

[322] Meves, H. The action of prostaglandins on ion channels. Curr. Neuropharmacol., 2006, 4(1), 41-57. [http://dx.doi.org/10.2174/ 157015906775203048] [PMID: 18615137]

[323] Harvey, R.J.; Depner, U.B.; Wässle, H.; Ahmadi, S.; Heindl, C.; Reinold, H.; Smart, T.G.; Harvey, K.; Schütz, B.; Abo-Salem, O.M.; Zimmer, A.; Poisbeau, P.; Welzl, H.; Wolfer, D.P.; Betz, H.; Zeilhofer, H.U.; Müller, U.; Gly, R. GlyR alpha3: an essential target for spinal PGE2-mediated inflammatory pain sensitization. Science, 2004, 304(5672), 884-887. [http://dx.doi.org/10.1126/ science.1094925] [PMID: 15131310]

[324] Parris, W. C.; Janicki, P. K.; Johnson, B., Jr; Horn, J. L. Intrathecal ketorolac tromethamine produces analgesia after chronic constriction injury of sciatic nerve in rat. Can. J. Anaesth., 1996, 43(8), 867870.

[325] Lee, I.O.; Seo, Y. The effects of intrathecal cyclooxygenase-1, cyclooxygenase-2, or nonselective inhibitors on pain behavior and spinal Fos-like immunoreactivity. Anesth. Analg., 2008, 106(3), 972-977. [http://dx.doi.org/10.1213/ane.0b013e318163f602] [PMID: 18292448]

[326] Malmberg, A.B.; Yaksh, T.L. Antinociceptive actions of spinal nonsteroidal anti-inflammatory agents on the formalin test in the rat J. Pharmacol. Exp. Ther., 1992, 263(1), 136-146. [PMID: 1403779]

[327] Zhu, X.; Conklin, D.R.; Eisenach, J.C. Preoperative inhibition of cyclooxygenase- 1 in the spinal cord reduces postoperative pain. Anesth. Analg., 2005, 100(5), 1390-1393. [http://dx.doi.org/10. 1213/01.ANE.0000148127.53832.8E] [PMID: 15845692]

[328] Yaksh, T. L.; Horais, K. A.; Tozier, N.; Rathbun, M.; Richter, P.; Rossi, S.; Grafe, M.; Tong, C.; Meschter, C.; Cline, J. M.; Eisenach, J. Intrathecal ketorolac in dogs and rats. Toxicol. Sci., 2004, 80(2), 322-334.

[329] Korkmaz, H.A.; Maltepe, F.; Erbayraktar, S.; Yilmaz, O.; Güray, M.; Canda, M.S.; Günerli, A.; Gökmen, N. Antinociceptive and neurotoxicologic screening of chronic intrathecal administration of ketorolac tromethamine in the rat. Anesth. Analg., 2004, 98(1), 148-152. [http://dx.doi.org/10.1213/01.ANE.0000093226.75543.90] [PMID: 14693610]

[330] Eisenach, J.C.; Curry, R.; Hood, D.D.; Yaksh, T.L. Phase I safety assessment of intrathecal ketorolac. Pain, 2002, 99(3), 599-604. [http://dx.doi.org/10.1016/S0304-3959(02)00208-7] [PMID: 12406536]

[331] Eisenach, J.C.; Curry, R.; Tong, C.; Houle, T.T.; Yaksh, T.L. Effects of intrathecal ketorolac on human experimental pain. Anesthesiology, 2010, 112(5), 1216-1224. [http://dx.doi.org/10. 1097/ALN.0b013e3181d94d8b] [PMID: 20395821]

[332] Lauretti, G.R.; Righeti, C.C.; Mattos, A.L. Intrathecal ketorolac enhances intrathecal morphine analgesia following total knee arthroplasty. J. Anaesthesiol. Clin. Pharmacol., 2013, 29(4), 503-508. [http://dx.doi.org/10.4103/0970-9185.119155] [PMID: 24249988]

[333] Eisenach, J.C.; Curry, R.; Rauck, R.; Pan, P.; Yaksh, T.L. Role of spinal cyclooxygenase in human postoperative and chronic pain. Anesthesiology, 2010, 112(5), 1225-1233. [http://dx.doi.org/10. 1097/ALN.0b013e3181d94dc0] [PMID: 20395820]

[334] Wang, L.; Bauer, M.; Curry, R.; Larsson, A.; Sessler, D.I.; Eisenach, J.C. Intrathecal ketorolac does not improve acute or chronic pain after hip arthroplasty: a randomized controlled trial. $J$. Anesth., 2014, 28(5), 790-793. [http://dx.doi.org/10.1007/s00540014-1798-6] [PMID: 24535482]

[335] Ferraguti, F.; Shigemoto, R. Metabotropic glutamate receptors. Cell Tissue Res., 2006, 326(2), 483-504. [http://dx.doi.org/10.1007/ s00441-006-0266-5] [PMID: 16847639]

[336] Ritter, S.L.; Hall, R.A. Fine-tuning of GPCR activity by receptorinteracting proteins. Nat. Rev. Mol. Cell Biol., 2009, 10(12), 819830. [http://dx.doi.org/10.1038/nrm2803] [PMID: 19935667]

[337] Osikowicz, M.; Mika, J.; Przewlocka, B. The glutamatergic system as a target for neuropathic pain relief. Exp. Physiol., 2013, 98(2), 372-384. [http://dx.doi.org/10.1113/expphysiol.2012.069922] [PMID: 23002244] 
[338] Boye, L.D.; Ingemann, K.G.; Panchalingam, V.; Laursen, J.C.; Nørgaard, P.J.; Skallerup, A.M.; Kandiah, A.; Gazerani, P. Investigating the expression of metabotropic glutamate receptors in trigeminal ganglion neurons and satellite glial cells: implications for craniofacial pain. J. Recept. Signal Transduct. Res., 2014, 34(4), 261-269. [http://dx.doi.org/10.3109/10799893.2014.885049] [PMID: 24495291]

[339] Shigemoto, R.; Kinoshita, A.; Wada, E.; Nomura, S.; Ohishi, H.; Takada, M.; Flor, P.J.; Neki, A.; Abe, T.; Nakanishi, S.; Mizuno, N. Differential presynaptic localization of metabotropic glutamate receptor subtypes in the rat hippocampus. J. Neurosci., 1997, 17(19), 7503-7522. [PMID: 9295396]

[340] Palazzo, E.; Marabese, I.; de Novellis, V.; Rossi, F.; Maione, S. Supraspinal metabotropic glutamate receptors: a target for pain relief and beyond. Eur. J. Neurosci., 2014, 39(3), 444-454. [http://dx.doi.org/10.1111/ejn.12398] [PMID: 24494684]

[341] Mills, C.D.; Johnson, K.M.; Hulsebosch, C.E. Group I metabotropic glutamate receptors in spinal cord injury: roles in neuroprotection and the development of chronic central pain. $J$. Neurotrauma, 2002, 19(1), 23-42. [http://dx.doi.org/10.1089/ 089771502753460213] [PMID: 11852976]

[342] Mills, C.D.; Johnson, K.M.; Hulsebosch, C.E. Role of group II and group III metabotropic glutamate receptors in spinal cord injury. Exp. Neurol., 2002, 173(1), 153-167. [http://dx.doi.org/10.1006/ exnr.2001.7828] [PMID: 11771948]

[343] Osikowicz, M.; Mika, J.; Makuch, W.; Przewlocka, B. Glutamate receptor ligands attenuate allodynia and hyperalgesia and potentiate morphine effects in a mouse model of neuropathic pain. Pain, 2008, 139(1), 117-126. [http://dx.doi.org/10.1016/j.pain.2008.03. 017] [PMID: 18442882]

[344] Fisher, K.; Coderre, T.J. Comparison of nociceptive effects produced by intrathecal administration of mGluR agonists. Neuroreport, 1996, 7(15-17), 2743-2747. [http://dx.doi.org/10.1097/ 00001756-199611040-00067] [PMID: 8981459]

[345] Fisher, K.; Coderre, T.J. The contribution of metabotropic glutamate receptors (mGluRs) to formalin-induced nociception. Pain, 1996, 68(2-3), 255-263. [http://dx.doi.org/10.1016/S03043959(96)03212-5] [PMID: 9121812]

[346] Zeilhofer, H.U. Loss of glycinergic and GABAergic inhibition in chronic paincontributions of inflammation and microglia. Int. Immunopharmacol., 2008, 8(2), 182-187. [http://dx.doi.org/10. 1016/j.intimp.2007.07.009] [PMID: 18182224]

[347] Goudet, C.; Chapuy, E.; Alloui, A.; Acher, F.; Pin, J.P.; Eschalier, A. Group III metabotropic glutamate receptors inhibit hyperalgesia in animal models of inflammation and neuropathic pain. Pain, 2008, 137(1), 112-124. [http://dx.doi.org/10.1016/j.pain.2007.08. 020] [PMID: 17900808]

[348] Ren, B.X.; Gu, X.P.; Zheng, Y.G.; Liu, C.L.; Wang, D.; Sun, Y.E.; $\mathrm{Ma}$, Z.L. Intrathecal injection of metabotropic glutamate receptor subtype 3 and 5 agonist/antagonist attenuates bone cancer pain by inhibition of spinal astrocyte activation in a mouse model. Anesthesiology, 2012, 116(1), 122-132. [http://dx.doi.org/10.1097/ ALN.0b013e31823de68d] [PMID: 22123524]

[349] Acher, F.; Goudet, C. Therapeutic potential of group III metabotropic glutamate receptor ligands in pain. Curr. Opin. Pharmacol., 2015, 20, 64-72. [http://dx.doi.org/10.1016/j.coph. 2014.11.007] [PMID: 25498980]

[350] Montana, M.C.; Gereau, R.W. Metabotropic glutamate receptors as targets for analgesia: antagonism, activation, and allosteric modulation. Curr. Pharm. Biotechnol., 2011, 12(10), 1681-1688. [http://dx. doi.org/10.2174/138920111798357438] [PMID: 21466446]

[351] Saito, O.; Svensson, C.I.; Buczynski, M.W.; Wegner, K.; Hua, X.Y.; Codeluppi, S.; Schaloske, R.H.; Deems, R.A.; Dennis, E.A.; Yaksh, T.L. Spinal glial TLR4-mediated nociception and production of prostaglandin $\mathrm{E}(2)$ and TNF. Br. J. Pharmacol., 2010, 160(7), 1754-1764. [http://dx.doi.org/10.1111/j.1476-5381. 2010.00811.x] [PMID: 20649577]

[352] Liu, T.; Gao, Y.J.; Ji, R.R. Emerging role of Toll-like receptors in the control of pain and itch. Neurosci. Bull., 2012, 28(2), 131-144. [http://dx.doi.org/10.1007/s12264-012-1219-5] [PMID: 22466124]

[353] Watkins, L.R.; Hutchinson, M.R.; Rice, K.C.; Maier, S.F. The toll of opioid-induced glial activation: improving the clinical efficacy of opioids by targeting glia. Trends Pharmacol. Sci., 2009, 30(11), 581-591. [http://dx.doi.org/10.1016/j.tips.2009.08.002] [PMID: $19762094]$
[354] Jacobsen, J.H.; Watkins, L.R.; Hutchinson, M.R. Discovery of a novel site of opioid action at the innate immune pattern-recognition receptor TLR4 and its role in addiction. Int. Rev. Neurobiol., 2014, 118, 129-163. [http://dx.doi.org/10.1016/B978-0-12-8012840.00006-3] [PMID: 25175864]

[355] Connolly, D.J.; ONeill, L.A. New developments in Toll-like receptor targeted therapeutics. Curr. Opin. Pharmacol., 2012, 12(4), 510-518. [http://dx.doi.org/10.1016/j.coph.2012.06.002] [PMID: 22748800]

[356] Lucas, K.; Maes, M. Role of the Toll Like receptor (TLR) radical cycle in chronic inflammation: possible treatments targeting the TLR4 pathway. Mol. Neurobiol., 2013, 48(1), 190-204. [http:// dx.doi.org/10.1007/s12035-013-8425-7] [PMID: 23436141]

[357] Wang, X.; Smith, C.; Yin, H. Targeting Toll-like receptors with small molecule agents. Chem. Soc. Rev., 2013, 42(12), 4859-4866. [http://dx.doi.org/10.1039/c3cs60039d] [PMID: 23503527]

[358] Vasileiou, I.; Fotopoulou, G.; Matzourani, M.; Patsouris, E.; Theocharis, S. Evidence for the involvement of cannabinoid receptors polymorphisms in the pathophysiology of human diseases. Expert Opin. Ther. Targets, 2013, 17(4), 363-377. [http://dx.doi. org/10.1517/14728222.2013.754426] [PMID: 23293857]

[359] Anand, P.; Whiteside, G.; Fowler, C.J.; Hohmann, A.G. Targeting $\mathrm{CB} 2$ receptors and the endocannabinoid system for the treatment of pain. Brain Res. Brain Res. Rev., 2009, 60(1), 255-266. [http://dx. doi.org/10.1016/j.brainresrev.2008.12.003] [PMID: 19150370]

[360] Starowicz, K.; Przewlocka, B. Modulation of neuropathic-painrelated behaviour by the spinal endocannabinoid/endovanilloid system. Philos. Trans. Royal Soc. Lond., 2012, 367(1607), 32863299.

[361] Cui, J.H.; Kim, W.M.; Lee, H.G.; Kim, Y.O.; Kim, C.M.; Yoon, M.H. Antinociceptive effect of intrathecal cannabinoid receptor agonist WIN 55,2122 in a rat bone tumor pain model. Neurosci. Lett., 2011, 493(3), 67-71. [http://dx.doi.org/10.1016/j.neulet.2010. 12.052] [PMID: 21195743]

[362] Cui, J.H.; Ju, J.; Yoon, M.H. Pharmacology of cannabinoid receptor agonists and a cyclooxygenase-2 inhibitor in rat bone tumor pain. Pharmacology, 2013, 92(3-4), 150-157. [http://dx.doi.org/10.1159/ 000354296] [PMID: 24008428]

[363] Wilkerson, J.L.; Gentry, K.R.; Dengler, E.C.; Wallace, J.A.; Kerwin, A.A.; Kuhn, M.N.; Zvonok, A.M.; Thakur, G.A.; Makriyannis, A.; Milligan, E.D. Immunofluorescent spectral analysis reveals the intrathecal cannabinoid agonist, AM1241, produces spinal anti-inflammatory cytokine responses in neuropathic rats exhibiting relief from allodynia. Brain Behav., 2012 2(2), 155-177. [http://dx.doi.org/10.1002/brb3.44] [PMID: 22574283]

[364] Burnstock, G. Physiology and pathophysiology of purinergic neurotransmission. Physiol. Rev., 2007, 87(2), 659-797. [http://dx. doi.org/10.1152/physrev.00043.2006] [PMID: 17429044]

[365] Abbracchio, M.P.; Burnstock, G.; Verkhratsky, A.; Zimmermann, $\mathrm{H}$. Purinergic signalling in the nervous system: an overview. Trends Neurosci., 2009, 32(1), 19-29. [http://dx.doi.org/10.1016/ j.tins.2008.10.001] [PMID: 19008000]

[366] Kobayashi, K.; Yamanaka, H.; Noguchi, K. Expression of ATP receptors in the rat dorsal root ganglion and spinal cord. Anat. Sci Int., 2013, 88(1), 10-16. [http://dx.doi.org/10.1007/s12565-0120163-9] [PMID: 23179910]

[367] Bianco, F.; Fumagalli, M.; Pravettoni, E.; DAmbrosi, N. Volonte, C.; Matteoli, M.; Abbracchio, M.P.; Verderio, C. Pathophysiological roles of extracellular nucleotides in glial cells: differential expression of purinergic receptors in resting and activated microglia. Brain Res. Brain Res. Rev., 2005, 48(2), $144-$ 156. [http://dx.doi.org/10.1016/j.brainresrev.2004.12.004] [PMID: 15850653 ]

[368] Inoue, K.; Tsuda, M. The role of microglia and ATP receptors in a mechanism of neuropathic pain. Nihon yakurigaku zasshi. Folia Pharmacologica Japonica, 2006, 127(1), 14-17.

[369] Jarvis, M.F. The neural-glial purinergic receptor ensemble in chronic pain states. Trends Neurosci., 2010, 33(1), 48-57. [http://dx.doi.org/10.1016/j.tins.2009.10.003] [PMID: 19914722]

[370] Clark, A.K.; Wodarski, R.; Guida, F.; Sasso, O.; Malcangio, M.; Cathepsin, S. Cathepsin S release from primary cultured microglia is regulated by the $\mathrm{P} 2 \mathrm{X} 7$ receptor. Glia, 2010, 58(14), 1710-1726. [http://dx.doi.org/10.1002/glia.21042] [PMID: 20629190]

[371] Donnelly-Roberts, D.; McGaraughty, S.; Shieh, C.C.; Honore, P.; Jarvis, M.F. Painful purinergic receptors. J. Pharmacol. Exp. Ther., 
2008, 324(2), 409-415. [http://dx.doi.org/10.1124/jpet.106.105890] [PMID: 18042830]

[372] Tsuda, M.; Shigemoto-Mogami, Y.; Koizumi, S.; Mizokoshi, A.; Kohsaka, S.; Salter, M.W.; Inoue, K. P2X4 receptors induced in spinal microglia gate tactile allodynia after nerve injury. Nature, 2003, 424(6950), 778-783. [http://dx.doi.org/10.1038/nature01786] [PMID: 12917686]

[373] Chessell, I.P.; Hatcher, J.P.; Bountra, C.; Michel, A.D.; Hughes, J.P.; Green, P.; Egerton, J.; Murfin, M.; Richardson, J.; Peck, W.L.; Grahames, C.B.; Casula, M.A.; Yiangou, Y.; Birch, R.; Anand, P.; Buell, G.N. Disruption of the P2X7 purinoceptor gene abolishes chronic inflammatory and neuropathic pain. Pain, 2005, 114(3), 386-396. [http://dx.doi.org/10.1016/j.pain.2005.01.002] [PMID: 15777864]

[374] Kobayashi, K.; Yamanaka, H.; Yanamoto, F.; Okubo, M.; Noguchi, $\mathrm{K}$. Multiple P2Y subtypes in spinal microglia are involved in neuropathic pain after peripheral nerve injury. Glia, 2012, 60(10), 15291539. [http://dx.doi.org/10.1002/glia.22373] [PMID: 22736439]

[375] Tozaki-Saitoh, H.; Tsuda, M.; Miyata, H.; Ueda, K.; Kohsaka, S.; Inoue, K. P2Y12 receptors in spinal microglia are required for neuropathic pain after peripheral nerve injury. J. Neurosci., 2008, 28(19), 4949-4956. [http://dx.doi.org/10.1523/JNEUROSCI.032308.2008] [PMID: 18463248]

[376] Trang, T.; Salter, M.W. P2X4 purinoceptor signaling in chronic pain. Purinergic Signal., 2012, 8(3), 621-628. [http://dx.doi.org/ 10.1007/s11302-012-9306-7] [PMID: 22528681]

[377] Sacerdote, P.; Franchi, S.; Moretti, S.; Castelli, M.; Procacci, P.; Magnaghi, V.; Panerai, A.E. Cytokine modulation is necessary for efficacious treatment of experimental neuropathic pain. J. Neuroimmune Pharmacol., 2013, 8(1), 202-211. [http://dx.doi.org/ 10.1007/s1 1481-012-9428-2] [PMID: 23242694]

[378] Opal, S.M.; DePalo, V.A. Anti-inflammatory cytokines. Chest, 2000, 117(4), 1162-1172. [http://dx.doi.org/10.1378/chest.117.4. 1162] [PMID: 10767254]

[379] Tayal, V.; Kalra, B.S. Cytokines and anti-cytokines as therapeuticsan update. Eur. J. Pharmacol., 2008, 579(1-3), 1-12. [http://dx.doi.org/10.1016/j.ejphar.2007.10.049] [PMID: 18021769]

[380] Milligan, E. D.; Penzkover, K. R.; Soderquist, R. G.; Mahoney, M. J. Spinal interleukin-10 therapy to treat peripheral neuropathic pain. Neuromodulation, 2012, 15(6), 520-526.

[381] Yaksh, T.L.; Farb, D.H.; Leeman, S.E.; Jessell, T.M. Intrathecal capsaicin depletes substance $\mathrm{P}$ in the rat spinal cord and produces prolonged thermal analgesia. Science, 1979, 206(4417), 481-483. [http://dx.doi.org/10.1126/science.228392] [PMID: 228392]

[382] Jhamandas, K.; Yaksh, T.L.; Harty, G.; Szolcsanyi, J.; Go, V.L. Action of intrathecal capsaicin and its structural analogues on the content and release of spinal substance P: selectivity of action and relationship to analgesia. Brain Res., 1984, 306(1-2), 215-225. [http://dx.doi.org/10.1016/0006-8993(84)90371-8] [PMID: 6205719]

[383] Szolcsanyi, J. Capsaicin and sensory neurones: a historical perspective. Prog. Drug Res. Fortschritte der Arzneimittelforschung. Progres des recherches pharmaceutiques, 2014, 68, 1-37.

[384] Brown, D.C.; Agnello, K.; Iadarola, M.J. Intrathecal resiniferatoxin in a dog model: efficacy in bone cancer pain. Pain, 2015, 156(6), 1018-1024. [PMID: 25659068]

[385] Binshtok, A.M.; Bean, B.P.; Woolf, C.J. Inhibition of nociceptors by TRPV1-mediated entry of impermeant sodium channel blockers. Nature, 2007, 449(7162), 607-610. [http://dx.doi.org/10.1038/ nature06191] [PMID: 17914397]

[386] Latapy, C.; Beaulieu, J.M. $\beta$-Arrestins in the central nervous system. Prog. Mol. Biol. Transl. Sci., 2013, 118, 267-295. [http://dx. doi.org/10.1016/B978-0-12-394440-5.00011-5] [PMID: 23764058]

[387] Wiley, R.G.; Lappi, D.A. Targeted toxins in pain. Adv. Drug Deliv. Rev., 2003, 55(8), 1043-1054. [http://dx.doi.org/10.1016/S0169409X(03)00102-9] [PMID: 12935943]

[388] Todd, A.J. Anatomy of primary afferents and projection neurones in the rat spinal dorsal horn with particular emphasis on substance $\mathrm{P}$ and the neurokinin 1 receptor. Exp. Physiol., 2002, 87(2), 245249. [http://dx.doi.org/10.1113/eph8702351] [PMID: 11856970]

[389] Khasabov, S.G.; Rogers, S.D.; Ghilardi, J.R.; Peters, C.M.; Mantyh, P.W.; Simone, D.A. Spinal neurons that possess the substance $\mathrm{P}$ receptor are required for the development of central sensitization. J. Neurosci., 2002, 22(20), 9086-9098. [PMID: $12388616]$
[390] Wiese, A.J.; Rathbun, M.; Butt, M.T.; Malkmus, S.A.; Richter, P.J.; Osborn, K.G.; Xu, Q.; Veesart, S.L.; Steinauer, J.J.; Higgins, D.; Lappi, D.A.; Russell, B.; Yaksh, T.L. Intrathecal substance Psaporin in the dog: distribution, safety, and spinal neurokinin-1 receptor ablation. Anesthesiology, 2013, 119(5), 1163-1177. [http:// dx.doi.org/10.1097/ALN.0b013e3182a95164] [PMID: 24051388]

[391] Pellett, S. Learning from the past: historical aspects of bacterial toxins as pharmaceuticals. Curr. Opin. Microbiol., 2012, 15(3), 292-299. [http://dx.doi.org/10.1016/j.mib.2012.05.005] [PMID: 22651975]

[392] Kakegawa, W.; Yuzaki, M. A mechanism underlying AMPA receptor trafficking during cerebellar long-term potentiation. Proc. Natl. Acad. Sci. USA, 2005, 102(49), 17846-17851. [http://dx.doi. org/10.1073/pnas.0508910102] [PMID: 16303868]

[393] Marinelli, S.; Luvisetto, S.; Cobianchi, S.; Makuch, W.; Obara, I.; Mezzaroma, E.; Caruso, M.; Straface, E.; Przewlocka, B.; Pavone, F. Botulinum neurotoxin type A counteracts neuropathic pain and facilitates functional recovery after peripheral nerve injury in animal models. Neuroscience, 2010, 171(1), 316-328. [http://dx.doi.org/ 10.1016/j.neuroscience.2010.08.067] [PMID: 20826198]

[394] Huang, P.P.; Khan, I.; Suhail, M.S.; Malkmus, S.; Yaksh, T.L. Spinal botulinum neurotoxin B: effects on afferent transmitter release and nociceptive processing. PLoS One, 2011, 6(4), e19126. [http://dx.doi.org/10.1371/journal.pone.0019126] [PMID: 21559464]

[395] Lee, W.H.; Shin, T.J.; Kim, H.J.; Lee, J.K.; Suh, H.W.; Lee, S.C.; Seo, K. Intrathecal administration of botulinum neurotoxin type A attenuates formalin-induced nociceptive responses in mice. Anesth. Analg., 2011, 112(1), 228-235. [http://dx.doi.org/10.1213/ANE. 0b013e3181ffa1d7] [PMID: 21081780]

[396] Coelho, A.; Oliveira, R.; Rossetto, O.; Cruz, C.D.; Cruz, F.; Avelino, A. Intrathecal administration of botulinum toxin type A improves urinary bladder function and reduces pain in rats with cystitis. Eur. J. Pain, 2014, 18(10), 1480-1489. [http://dx.doi.org/ 10.1002/ejp.513] [PMID: 24756904]

[397] Ramachandran, R.; Yaksh, T.L. Therapeutic use of botulinum toxin in migraine: mechanisms of action. Br. J. Pharmacol., 2014, 171(18), 4177-4192. [http://dx.doi.org/10.1111/bph.12763] [PMID 24819339]

[398] Matak, I.; Lacković, Z. Botulinum toxin A, brain and pain. Prog. Neurobiol., 2014, 119-120, 39-59. [http://dx.doi.org/10.1016/ j.pneurobio.2014.06.001] [PMID: 24915026]

[399] Carroll, I.; Fischbein, N.; Barad, M.; Mackey, S. Human response to unintended intrathecal injection of botulinum toxin. Pain Med. 2011, 12(7), 1094-1097. [http://dx.doi.org/10.1111/j.1526-4637. 2011.01135.x] [PMID: 21627762]

[400] Mustafa, G.; Anderson, E.M.; Bokrand-Donatelli, Y.; Neubert, J.K.; Caudle, R.M. Anti-nociceptive effect of a conjugate of substance $\mathrm{P}$ and light chain of botulinum neurotoxin type A. Pain, 2013, 154(11), 2547-2553. [http://dx.doi.org/10.1016/j.pain.2013. 07.041] [PMID: 23933181]

[401] Röhl, T.; Kurreck, J. RNA interference in pain research. $J$ Neurochem., 2006, 99(2), 371-380. [http://dx.doi.org/10.1111/ j.1471-4159.2006.04082.x] [PMID: 17029593]

[402] Dominguez, E.; Meunier, A.; Pohl, M. Gene-based approaches in the study of pathological pain. Methods Mol. Biol., 2010, 617, 297-308. [http://dx.doi.org/10.1007/978-1-60327-323-7 22] [PMID: 20336430]

[403] Molet, J.; Pohl, M. Gene-based approaches in pain research and exploration of new therapeutic targets and strategies. Eur. $J$. Pharmacol., 2013, 716(1-3), 129-141. [http://dx.doi.org/10.1016/ j.ejphar.2013.01.073] [PMID: 23500201]

[404] Kim, D.S.; Li, K.W.; Boroujerdi, A.; Peter Yu, Y.; Zhou, C.Y.; Deng, P.; Park, J.; Zhang, X.; Lee, J.; Corpe, M.; Sharp, K.; Steward, O.; Eroglu, C.; Barres, B.; Zaucke, F.; Xu, Z.C.; Luo, Z.D. Thrombospondin-4 contributes to spinal sensitization and neuropathic pain states. J. Neurosci., 2012, 32(26), 8977-8987. [http://dx.doi.org/10.1523/JNEUROSCI.6494-11.2012] [PMID: 22745497]

[405] Hua, X.Y.; Chen, P.; Polgar, E.; Nagy, I.; Marsala, M.; Phillips, E.; Wollaston, L.; Urban, L.; Yaksh, T.L.; Webb, M. Spinal neurokinin NK1 receptor down-regulation and antinociception: effects of spinal NK1 receptor antisense oligonucleotides and NK1 receptor occupancy. J. Neurochem., 1998, 70(2), 688-698. [http://dx.doi. org/10.1046/j.1471-4159.1998.70020688.x] [PMID: 9453563] 
[406] Alvarez, P.; Chen, X.; Bogen, O.; Green, P.G.; Levine, J.D. IB4(+) nociceptors mediate persistent muscle pain induced by GDNF. $J$. Neurophysiol., 2012, 108(9), 2545-2553. [http://dx.doi.org/10. 1152/jn.00576.2012] [PMID: 22914655]

[407] Tan, P.H.; Yang, L.C.; Shih, H.C.; Lan, K.C.; Cheng, J.T. Gene knockdown with intrathecal siRNA of NMDA receptor NR2B subunit reduces formalin-induced nociception in the rat. Gene Ther., 2005, 12(1), 59-66. [http://dx.doi.org/10.1038/sj.gt.3302376] [PMID: 15470478]

[408] Fundytus, M.E.; Yashpal, K.; Chabot, J.G.; Osborne, M.G.; Lefebvre, C.D.; Dray, A.; Henry, J.L.; Coderre, T.J. Knockdown of spinal metabotropic glutamate receptor $1(\operatorname{mGluR}(1))$ alleviates pain and restores opioid efficacy after nerve injury in rats. $B r . J$. Pharmacol., 2001, 132(1), 354-367. [http://dx.doi.org/10.1038/sj. bjp.0703810] [PMID: 11156596]

[409] Fundytus, M.E.; Osborne, M.G.; Henry, J.L.; Coderre, T.J.; Dray, A. Antisense oligonucleotide knockdown of mGluR1 alleviates hyperalgesia and allodynia associated with chronic inflammation. Pharmacol. Biochem. Behav., 2002, 73(2), 401-410. [http://dx. doi.org/10.1016/S0091-3057(02)00831-6] [PMID: 12117595]

[410] Chen, M.; Zhang, X.; Xu, H.; Ma, X.; Jiang, W.; Xu, T. Inhibitory effect of spinal $\mathrm{mGlu}(5)$ receptor antisense oligonucleotide on the up-regulated expression of spinal $\mathrm{G}$ protein associated with chronic morphine treatment. Eur. J. Pharmacol., 2014, 723, 253-258. [http://dx.doi.org/10.1016/j.ejphar.2013.11.024] [PMID: 24296320]

[411] Barclay, J.; Patel, S.; Dorn, G.; Wotherspoon, G.; Moffatt, S.; Eunson, L.; Abdelal, S.; Natt, F.; Hall, J.; Winter, J.; Bevan, S.; Wishart, W.; Fox, A.; Ganju, P. Functional downregulation of $\mathrm{P} 2 \mathrm{X} 3$ receptor subunit in rat sensory neurons reveals a significant role in chronic neuropathic and inflammatory pain. J. Neurosci., 2002, 22(18), 8139-8147. [PMID: 12223568]

[412] Dorn, G.; AbdelAl, S.; Natt, F.J.; Weiler, J.; Hall, J.; Meigel, I.; Mosbacher, J.; Wishart, W. Specific inhibition of the rat ligandgated ion channel $\mathrm{P} 2 \mathrm{X} 3$ function via methoxyethoxy-modified phosphorothioated antisense oligonucleotides. Antisense Nucleic Acid Drug Dev., 2001, 11(3), 165-174. [http://dx.doi.org/10.1089/ 108729001300338690] [PMID: 11446592]

[413] Wu, Z.; Yang, Q.; Crook, R.J.; ONeil, R.G.; Walters, E.T. TRPV1 channels make major contributions to behavioral hypersensitivity and spontaneous activity in nociceptors after spinal cord injury. Pain, 2013, 154(10), 2130-2141. [http://dx.doi.org/10.1016/j.pain. 2013.06.040] [PMID: 23811042]

[414] Alvarez, P.; Green, P.G.; Levine, J.D. Role for monocyte chemoattractant protein-1 in the induction of chronic muscle pain in the rat. Pain, 2014, 155(6), 1161-1167. [http://dx.doi.org/10. 1016/j.pain.2014.03.004] [PMID: 24637038]

[415] Yao, Y.X.; Jiang, Z.; Zhao, Z.Q. Knockdown of synaptic scaffolding protein Homer $1 \mathrm{~b} / \mathrm{c}$ attenuates secondary hyperalgesia induced by complete Freunds adjuvant in rats. Anesth. Analg., 2011, 113(6), 1501-1508. [http://dx.doi.org/10.1213/ANE.0b013 e31822c0b98] [PMID: 22003220]

[416] Svensson, C.I.; Lucas, K.K.; Hua, X.Y.; Powell, H.C.; Dennis, E.A.; Yaksh, T.L. Spinal phospholipase A2 in inflammatory hyperalgesia: role of the small, secretory phospholipase A2. Neuroscience, 2005, 133(2), 543-553. [http://dx.doi.org/10.1016/j. neuroscience.2005.01.024] [PMID: 15885922]

[417] Fitzsimmons, B.L.; Zattoni, M.; Svensson, C.I.; Steinauer, J.; Hua, X.Y.; Yaksh, T.L. Role of spinal p38alpha and beta MAPK in inflammatory hyperalgesia and spinal COX-2 expression. Neuroreport, 2010, 21(4), 313-317. [http://dx.doi.org/10.1097/ WNR.0b013e32833774bf] [PMID: 20134354]

[418] Kim, D.H.; Fitzsimmons, B.; Hefferan, M.P.; Svensson, C.I.; Wancewicz, E.; Monia, B.P.; Hung, G.; Butler, M.; Marsala, M.; Hua, X.Y.; Yaksh, T.L. Inhibition of spinal cytosolic phospholipase $\mathrm{A}(2)$ expression by an antisense oligonucleotide attenuates tissue injury-induced hyperalgesia. Neuroscience, 2008, 154(3), 10771087. [http://dx.doi.org/10.1016/j.neuroscience.2008.04.033] [PMID: $18511207]$

[419] Lai, J.; Gold, M.S.; Kim, C.S.; Bian, D.; Ossipov, M.H.; Hunter, J.C.; Porreca, F. Inhibition of neuropathic pain by decreased expression of the tetrodotoxin-resistant sodium channel, NaV1.8. Pain, 2002, 95(1-2), 143-152. [http://dx.doi.org/10.1016/S03043959(01)00391-8] [PMID: 11790477]

[420] Parada, C.A.; Vivancos, G.G.; Tambeli, C.H.; Cunha, F.Q.; Ferreira, S.H. Activation of presynaptic NMDA receptors coupled to NaV1.8-resistant sodium channel C-fibers causes retrograde mechanical nociceptor sensitization. Proc. Natl. Acad. Sci. USA, 2003, 100(5), 2923-2928. [http://dx.doi.org/10.1073/pnas.252777799] [PMID: 12589028]

[421] Bourinet, E.; Alloui, A.; Monteil, A.; Barrère, C.; Couette, B.; Poirot, O.; Pages, A.; McRory, J.; Snutch, T.P.; Eschalier, A.; Nargeot, J. Silencing of the Cav3.2 T-type calcium channel gene in sensory neurons demonstrates its major role in nociception. EMBO J., 2005, 24(2), 315-324. [http://dx.doi.org/10.1038/sj.emboj. 7600515] [PMID: 15616581]

[422] Wen, X.J.; Li, Z.J.; Chen, Z.X.; Fang, Z.Y.; Yang, C.X.; Li, H.; Zeng, Y.M. Intrathecal administration of Cav3.2 and Cav3.3 antisense oligonucleotide reverses tactile allodynia and thermal hyperalgesia in rats following chronic compression of dorsal root of ganglion. Acta Pharmacol. Sin., 2006, 27(12), 1547-1552. [http:// dx.doi.org/10.1111/j.1745-7254.2006.00461.x] [PMID: 17112407]

[423] Mamet, J.; Klukinov, M.; Yaksh, T.L.; Malkmus, S.A.; Williams, S.; Harris, S.; Manning, D.C.; Taylor, B.K.; Donahue, R.R.; Porreca, F.; Xie, J.Y.; Oyarzo, J.; Brennan, T.J.; Subieta, A.; Schmidt, W.K.; Yeomans, D.C. Single intrathecal administration of the transcription factor decoy AYX1 prevents acute and chronic pain after incisional, inflammatory, or neuropathic injury. Pain, 2014, 155(2), 322-333. [http://dx.doi.org/10.1016/j.pain.2013.10.015] [PMID: 24145208]

[424] Storek, B.; Reinhardt, M.; Wang, C.; Janssen, W.G.; Harder, N.M.; Banck, M.S.; Morrison, J.H.; Beutler, A.S. Sensory neuron targeting by self-complementary AAV8 via lumbar puncture for chronic pain. Proc. Natl. Acad. Sci. USA, 2008, 105(3), 1055-1060. [http://dx.doi.org/10.1073/pnas.0708003105] [PMID: 18215993]

[425] Tzabazis, A.Z.; Klukinov, M.; Feliciano, D.P.; Wilson, S.P.; Yeomans, D.C. Gene therapy for trigeminal pain in mice. Gene Ther., 2014, 21(4), 422-426. [http://dx.doi.org/10.1038/gt.2014.14] [PMID: 24572785]

[426] Wu, F.; Xu, X.; Miao, X.; Chen, J.; Sun, Y.; Yu, W. Effect of recombinant adenovirus coding for endomorphin-2 on neuropathic pain in rats. Int. J. Clin. Exp. Pathol., 2012, 5(9), 914-923. [PMID: 23119108]

[427] Goss, J.R.; Mata, M.; Goins, W.F.; Wu, H.H.; Glorioso, J.C.; Fink, D.J. Antinociceptive effect of a genomic herpes simplex virusbased vector expressing human proenkephalin in rat dorsal root ganglion. Gene Ther., 2001, 8(7), 551-556. [http://dx.doi.org/ 10.1038/sj.gt.3301430] [PMID: 11319622]

[428] Wu, C.M.; Lin, M.W.; Cheng, J.T.; Wang, Y.M.; Huang, Y.W.; Sun, W.Z.; Lin, C.R. Regulated, electroporation-mediated delivery of pro-opiomelanocortin gene suppresses chronic constriction injury-induced neuropathic pain in rats. Gene Ther., 2004, 11(11), 933940. [http://dx.doi.org/10.1038/sj.gt.3302244] [PMID: 15116065]

[429] Milligan, E.D.; Sloane, E.M.; Langer, S.J.; Cruz, P.E.; Chacur, M.; Spataro, L.; Wieseler-Frank, J.; Hammack, S.E.; Maier, S.F.; Flotte, T.R.; Forsayeth, J.R.; Leinwand, L.A.; Chavez, R.; Watkins, L.R. Controlling neuropathic pain by adeno-associated virus driven production of the anti-inflammatory cytokine, interleukin-10. Mol. Pain, 2005, 1, 9. [http://dx.doi.org/10.1186/1744-8069-1-9] [PMID: 15813997]

[430] Soderquist, R.G.; Sloane, E.M.; Loram, L.C.; Harrison, J.A.; Dengler, E.C.; Johnson, S.M.; Amer, L.D.; Young, C.S.; Lewis M.T.; Poole, S.; Frank, M.G.; Watkins, L.R.; Milligan, E.D.; Mahoney, M.J. Release of plasmid DNA-encoding IL-10 from PLGA microparticles facilitates long-term reversal of neuropathic pain following a single intrathecal administration. Pharm. Res., 2010, 27(5), 841-854. [http://dx.doi.org/10.1007/s1 1095-010-0077y] [PMID: 20224990]

[431] Pleticha, J.; Malkmus, S.A.; Heilmann, L.F.; Veesart, S.L.; Rezek, R.; Xu, Q.; Yaksh, T.L.; Beutler, A.S. High cerebrospinal fluid levels of interleukin-10 attained by AAV in dogs. Gene Ther. 2015, 22(2), 202-208. [http://dx.doi.org/10.1038/gt.2014.96] [PMID: 25354684]

[432] Ndong, C.; Landry, R.P.; DeLeo, J.A.; Romero-Sandoval, E.A Mitogen activated protein kinase phosphatase-1 prevents the development of tactile sensitivity in a rodent model of neuropathic pain. Mol. Pain, 2012, 8, 34. [http://dx.doi.org/10.1186/1744-80698-34] [PMID: 22540262]

[433] Fischer, G.; Pan, B.; Vilceanu, D.; Hogan, Q.H.; Yu, H. Sustained relief of neuropathic pain by AAV-targeted expression of CBD3 
peptide in rat dorsal root ganglion. Gene Ther., 2014, 21(1), 44-51. [http://dx.doi.org/10.1038/gt.2013.56] [PMID: 24152582]

[434] Fan, L.; Guan, X.; Wang, W.; Zhao, J.Y.; Zhang, H.; Tiwari, V.; Hoffman, P.N.; Li, M.; Tao, Y.X. Impaired neuropathic pain and preserved acute pain in rats overexpressing voltage-gated potassium channel subunit Kv1.2 in primary afferent neurons. Mol. Pain, 2014, 10(1), 8. [http://dx.doi.org/10.1186/1744-8069-10-8] [PMID: 24472174]

[435] Chattopadhyay, M.; Zhou, Z.; Hao, S.; Mata, M.; Fink, D.J. Reduction of voltage gated sodium channel protein in DRG by vector mediated miRNA reduces pain in rats with painful diabetic neuropathy. Mol. Pain, 2012, 8, 17. [http://dx.doi.org/10.1186/ 1744-8069-8-17] [PMID: 22439790]

[436] Xu, Q.; Chou, B.; Fitzsimmons, B.; Miyanohara, A.; Shubayev, V.; Santucci, C.; Hefferan, M.; Marsala, M.; Hua, X.Y. In vivo gene knockdown in rat dorsal root ganglia mediated by selfcomplementary adeno-associated virus serotype 5 following intrathecal delivery. PLoS One, 2012, 7(3), e32581. [http://dx.doi.org/ 10.1371/journal.pone.0032581] [PMID: 22403675]

[437] Beutler, A.S.; Banck, M.S.; Walsh, C.E.; Milligan, E.D. Intrathecal gene transfer by adeno-associated virus for pain. Curr. Opin. Mol. Ther., 2005, 7(5), 431-439. [PMID: 16248278]

[438] Hutchings, M.; Weller, R.O. Anatomical relationships of the pia mater to cerebral blood vessels in man. J. Neurosurg., 1986, 65(3), 316-325. [http://dx.doi.org/10.3171/jns.1986.65.3.0316] [PMID: 3734882]

[439] Cloyd, M.W.; Low, F.N. Scanning electron microscopy of the subarachnoid space in the dog. I. Spinal cord levels. J. Comp. Neurol., 1974, 153(4), 325-368. [http://dx.doi.org/10.1002/cne. 901530402] [PMID: 4816519]

[440] Filippidis, A. S.; Zarogiannis, S. G.; Ioannou, M.; Gourgoulianis, K.; Molyvdas, P. A.; Hatzoglou, C. Permeability of the arachnoid and pia mater. Child's Nervous System, 2012, 28(4), 533-540.

[441] Vulchanova, L.; Schuster, D.J.; Belur, L.R.; Riedl, M.S.; PodetzPedersen, K.M.; Kitto, K.F.; Wilcox, G.L.; McIvor, R.S.; Fairbanks, C.A. Differential adeno-associated virus mediated gene transfer to sensory neurons following intrathecal delivery by direct lumbar puncture. Mol. Pain, 2010, 6, 31. [http://dx.doi.org/10. 1186/1744-8069-6-31] [PMID: 20509925]

[442] Wall, P.D.; Shortland, P. Long-range afferents in the rat spinal cord. 1. Numbers, distances and conduction velocities. Philos. Trans. R. Soc. Lond. B Biol. Sci., 1991, 334(1269), 85-93. [http:// dx.doi.org/10.1098/rstb.1991.0098] [PMID: 1684674]

[443] Shortland, P.; Wall, P.D. Long-range afferents in the rat spinal cord. II. Arborizations that penetrate grey matter. Philos. Trans. $R$. Soc. Lond. B Biol. Sci., 1992, 337(1282), 445-455. [http://dx.doi. org/10.1098/rstb.1992.0120] [PMID: 1279734]

[444] Hylden, J.L.; Wilcox, G.L. Intrathecal opioids block a spinal action of substance $\mathrm{P}$ in mice: functional importance of both mu- and delta-receptors. Eur. J. Pharmacol., 1982, 86(1), 95-98. [http://dx. doi.org/10.1016/0014-2999(82)90403-4] [PMID: 6186500]

[445] Yaksh, T.L. Analgetic actions of intrathecal opiates in cat and primate. Brain Res., 1978, 153(1), 205-210. [http://dx.doi.org/ 10.1016/0006-8993(78)91146-0] [PMID: 98219]

[446] Yaksh, T.L.; Noueihed, R.Y.; Durant, P.A. Studies of the pharmacology and pathology of intrathecally administered 4anilinopiperidine analogues and morphine in the rat and cat. Anesthesiology, 1986, 64(1), 54-66. [http://dx.doi.org/10.1097/ 00000542-198601000-00009] [PMID: 2867722]

[447] Sabbe, M.B.; Grafe, M.R.; Mjanger, E.; Tiseo, P.J.; Hill, H.F.; Yaksh, T.L. Spinal delivery of sufentanil, alfentanil, and morphine in dogs. Physiologic and toxicologic investigations. Anesthesiology, 1994, 81(4), 899-920. [http://dx.doi.org/10.1097/00000542-19941000000017] [PMID: 7943841]

[448] Nordberg, G.; Hedner, T.; Mellstrand, T.; Dahlström, B. Pharmacokinetic aspects of intrathecal morphine analgesia. Anesthesiology, 1984, 60(5), 448-454. [http://dx.doi.org/10.1097/ 00000542-198405000-00010] [PMID: 6546839]

[449] Lipman, J.J.; Blumenkopf, B. Comparison of subjective and objective analgesic effects of intravenous and intrathecal morphine in chronic pain patients by heat beam dolorimetry. Pain, 1989, 39(3), 249-256. [http://dx.doi.org/10.1016/0304-3959(89)90037-7] [PMID: 2616177]

[450] Suzukawa, M.; Matsumoto, M.; Collins, J.G.; Kitahata, L.M.; Yuge, O. Dose-response suppression of noxiously evoked activity of
WDR neurons by spinally administered fentanyl. Anesthesiology, 1983, 58(6), 510-513. [http://dx.doi.org/10.1097/00000542-19830600000005] [PMID: 6859581]

[451] Homma, E.; Collins, J.G.; Kitahata, L.M.; Matsumoto, M.; Kawahara, M. Suppression of noxiously evoked WDR dorsal horn neuronal activity by spinally administered morphine. Anesthesiology, 1983, 58(3), 232-236. [http://dx.doi.org/10.1097/00000542-19830300000005] [PMID: 6829958]

[452] Bujedo, B.M.; Santos, S.G.; Azpiazu, A.U. A review of epidural and intrathecal opioids used in the management of postoperative pain. J. Opioid Manag., 2012, 8(3), 177-192. [http://dx.doi.org/ 10.5055/jom.2012.0114] [PMID: 22798178]

[453] Syková, E.; Nicholson, C. Diffusion in brain extracellular space. Physiol. Rev., 2008, 88(4), 1277-1340. [http://dx.doi.org/10.1152/ physrev.00027.2007] [PMID: 18923183]

[454] Wolak, D.J.; Thorne, R.G. Diffusion of macromolecules in the brain: implications for drug delivery. Mol. Pharm., 2013, 10(5), 14921504. [http://dx.doi.org/10.1021/mp300495e] [PMID: 23298378]

[455] Schroth, G.; Klose, U. Cerebrospinal fluid flow. I. Physiology of cardiac-related pulsation. Neuroradiology, 1992, 35(1), 1-9. [http://dx.doi.org/10.1007/BF00588270] [PMID: 1289731]

[456] Schroth, G.; Klose, U. Cerebrospinal fluid flow. II. Physiology of respiration-related pulsations. Neuroradiology, 1992, 35(1), 10-15. [http://dx.doi.org/10.1007/BF00588271] [PMID: 1289732]

[457] Bernards, C.M. Cerebrospinal fluid and spinal cord distribution of baclofen and bupivacaine during slow intrathecal infusion in pigs. Anesthesiology, 2006, 105(1), 169-178. [http://dx.doi.org/10.1097/ 00000542-200607000-00027] [PMID: 16810009]

[458] Flack, S.H.; Anderson, C.M.; Bernards, C. Morphine distribution in the spinal cord after chronic infusion in pigs. Anesth. Analg., 2011, 112(2), 460-464. [http://dx.doi.org/10.1213/ANE.0b013e318203b7c0] [PMID: 21212256]

[459] Flack, S.H.; Bernards, C.M. Cerebrospinal fluid and spinal cord distribution of hyperbaric bupivacaine and baclofen during slow intrathecal infusion in pigs. Anesthesiology, 2010, 112(1), 165-173. [http://dx.doi.org/10.1097/ALN.0b013e3181c38da5] [PMID: 19996952]

[460] Wallace, M.; Yaksh, T.L. Characteristics of distribution of morphine and metabolites in cerebrospinal fluid and plasma with chronic intrathecal morphine infusion in humans. Anesth Analg., 2012, 115(4), 797-804. [http://dx.doi.org/10.1213/ANE.0b013 e3182645dfd] [PMID: 22822192]

[461] Yaksh, T.L.; Hassenbusch, S.; Burchiel, K.; Hildebrand, K.R.; Page, L.M.; Coffey, R.J. Inflammatory masses associated with intrathecal drug infusion: a review of preclinical evidence and human data. Pain Med., 2002, 3(4), 300-312. [http://dx.doi.org/ 10.1046/j.1526-4637.2002.02048.x] [PMID: 15099235]

[462] Yaksh, T.L. Spinal Delivery and Assessment of Drug Safety. In: Fundamental Neuropathology for Pathologists and Toxicologists; Principles and Techniques, 2011; pp. 451-462. [http://dx.doi.org/ 10.1002/9780470939956.ch27]

[463] Bhatia, G.; Lau, M.E.; Koury, K.M.; Gulur, P. Intrathecal Drug Delivery (ITDD) systems for cancer pain. F1000 Res., 2013, 2, 96. [PMID: 24555051]

[464] Deer, T.R.; Raso, L.J.; Garten, T.G. Inflammatory mass of an intrathecal catheter in patients receiving baclofen as a sole agent: a report of two cases and a review of the identification and treatment of the complication. Pain Med., 2007, 8(3), 259-262. [http://dx.doi. org/10.1111/j.1526-4637.2006.00150.x] [PMID: 17371413]

[465] Grouls, R.J.; Korsten, E.H.; Yaksh, T.L. General considerations for the formulation of drugs for spinal delivery. In: Spinal Drug Delivery; Yaksh, T.L., Ed.; Elsevier Science B.V.: Amsterdam, 1999; pp. 371-393.

[466] Lagarce, F.; Benoit, J.P. Sustained release formulations for spinal drug delivery. J. Drug Deliv. Sci. Technol., 2004, 14(5), 331-343. [http://dx.doi.org/10.1016/S1773-2247(04)50061-8]

[467] Yaksh, T.L.; Jang, J.D.; Nishiuchi, Y.; Braun, K.P.; Ro, S.G.; Goodman, M. The utility of 2-hydroxypropyl-beta-cyclodextrin as a vehicle for the intracerebral and intrathecal administration of drugs. Life Sci., 1991, 48(7), 623-633. [http://dx.doi.org/10.1016/ 0024-3205(91)90537-L] [PMID: 1703620]

[468] Jang, J.; Yaksh, T.L.; Hill, H.F. Use of 2-hydroxypropyl-betacyclodextrin as an intrathecal drug vehicle with opioids. $J$ Pharmacol. Exp. Ther., 1992, 261(2), 592-600. [PMID: 1349642] 
[469] Meert, T.F.; Mesens, J.; Verheyen, P.; Noorduin, H. Hydroxypropylbeta-cyclodextrin can modulate the activity of spinally administered sufentanil. Eur. J. Anaesthesiol., 1992, 9(5), 399-409. [PMID: 1396627]

[470] Yaksh, T.L.; Malmberg, A.B.; Ro, S.; Schiller, P.; Goodman, M. Characterization of the spinal antinociceptive activity of constrained peptidomimetic opioids. J. Pharmacol. Exp. Ther., 1995, 275(1), 63-72. [PMID: 7562596]

[471] Lagarce, F.; Faisant, N.; Desfontis, J.C.; Marescaux, L.; Gautier, F.; Holopherne, D.; Rousselet, M.C.; Menei, P.; Benoit, J.P. Biopharmaceutics of intrathecal baclofen-loaded microparticles in a goat model. Int. J. Pharm., 2005, 298(1), 68-79. [http://dx.doi.org/ 10.1016/j.ijpharm.2005.03.025] [PMID: 15919163]

[472] Lagarce, F.; Faisant, N.; Desfontis, J. C.; Marescaux, L.; Gautier, F.; Richard, J.; Menei, P.; Benoit, J. P. Baclofen-loaded microspheres in gel suspensions for intrathecal drug delivery: in vitro and in vivo evaluation. Eur. J. Pharm. Biopharm., 2005, 61(3), 171-180.

[473] Hildebrand, K.R.; Elsberry, D.D.; Hassenbusch, S.J. Stability and compatibility of morphine-clonidine admixtures in an implantable infusion system. J. Pain Symptom Manage., 2003, 25(5), 464-471. [http://dx.doi.org/10.1016/S0885-3924(03)00041-1] [PMID: 12727045]

[474] Classen, A.M.; Wimbish, G.H.; Kupiec, T.C. Stability of admixture containing morphine sulfate, bupivacaine hydrochloride, and clonidine hydrochloride in an implantable infusion system. J. Pain Symptom Manage., 2004, 28(6), 603-611. [http://dx.doi.org/ 10.1016/j.jpainsymman.2004.04.011] [PMID: 15589086]

[475] Ward, K. W.; Nagilla, R.; Jolivette, L. J. Comparative evaluation of oral systemic exposure of 56 xenobiotics in rat, dog, monkey and human. Xenobiotica, 2005, 35(2), 191-210.

[476] Bergadano, A.; Andersen, O.K.; Arendt-Nielsen, L.; Spadavecchia, C. Noninvasive assessment of the facilitation of the nociceptive withdrawal reflex by repeated electrical stimulations in conscious dogs. Am. J. Vet. Res., 2007, 68(8), 899-907. [http://dx.doi.org/ 10.2460/ajvr.68.8.899] [PMID: 17669031]

[477] Wegner, K.; Horais, K.A.; Tozier, N.A.; Rathbun, M.L.; Shtaerman, Y.; Yaksh, T.L. Development of a canine nociceptive thermal escape model. J. Neurosci. Methods, 2008, 168(1), 88-97. [http://dx.doi.org/10.1016/j.jneumeth.2007.09.019] [PMID: 18054083]

[478] Watabiki, T.; Nagakura, Y.; Wegner, K.; Kakimoto, S.; Tozier, N.A.; Malkmus, S.A.; Yaksh, T.L. Assessment of canine sensory function by using sine-wave electrical stimuli paradigm. Physiol. Behav., 2010, 101(3), 327-330. [http://dx.doi.org/10.1016/j. physbeh.2010.05.019] [PMID: 20570687]

[479] Rohrbach, H.; Zeiter, S.; Andersen, O.K.; Wieling, R.; Spadavecchia, C. Quantitative assessment of the nociceptive withdrawal reflex in healthy, non-medicated experimental sheep. Physiol. Behav., 2014, 129, 181-185. [http://dx.doi.org/10.1016/ j.physbeh.2014.02.017] [PMID: 24561088]

[480] Rohrbach, H.; Andersen, O.K.; Zeiter, S.; Wieling, R.; Spadavecchia, C. Repeated electrical stimulations as a tool to evoke temporal summation of nociceptive inputs in healthy, non-medicated experimental sheep. Physiol. Behav., 2015, 142, 85-89. [http://dx. doi.org/10.1016/j.physbeh.2015.02.008] [PMID: 25659734]

[481] Piel, M.J.; Kroin, J.S.; van Wijnen, A.J.; Kc, R.; Im, H.J. Pain assessment in animal models of osteoarthritis. Gene, 2014, 537(2), 184188. [http://dx.doi.org/10.1016/j.gene.2013.11.091] [PMID: 24333346]

[482] Brimmo, O.A.; Pfeiffer, F.; Bozynski, C.C.; Kuroki, K.; Cook, C.; Stoker, A.; Sherman, S.L.; Monibi, F.; Cook, J.L. Development of a Novel Canine Model for Posttraumatic Osteoarthritis of the Knee. J. Knee Surg., 2015. [http://dx.doi.org/10.1055/s-0035-1549026] [PMID: 25892003]

[483] McCarty, D.J., Jr; Phelps, P.; Pyenson, J. Crystal-induced inflammation in canine joints. I. An experimental model with quantification of the host response. J. Exp. Med., 1966, 124(1), 99114. [http://dx.doi.org/10.1084/jem.124.1.99] [PMID: 4287616]
[484] Lopez, M.J.; Kunz, D.; Vanderby, R., Jr; Heisey, D.; Bogdanske, J.; Markel, M.D. A comparison of joint stability between anterior cruciate intact and deficient knees: a new canine model of anterior cruciate ligament disruption. J. Orthop. Res., 2003, 21(2), 224-230. [http://dx.doi.org/10.1016/S0736-0266(02)00132-8] [PMID: 12568952]

[485] Budsberg, S.C. Long-term temporal evaluation of ground reaction forces during development of experimentally induced osteoarthritis in dogs. Am. J. Vet. Res., 2001, 62(8), 1207-1211. [http://dx.doi. org/10.2460/ajvr.2001.62.1207] [PMID: 11497439]

[486] Marshall, W.; Bockstahler, B.; Hulse, D.; Carmichael, S. A review of osteoarthritis and obesity: current understanding of the relationship and benefit of obesity treatment and prevention in the dog. Vet. Comp. Orthop. Traumatol., 2009, 22(5), 339-345. [PMID: 19750285]

[487] Ru, G.; Terracini, B.; Glickman, L.T. Host related risk factors for canine osteosarcoma. Vet. J., 1998, 156(1), 31-39. [http://dx. doi.org/10.1016/S1090-0233(98)80059-2] [PMID: 9691849]

[488] Brown, D.C.; Bell, M.; Rhodes, L. Power of treatment success definitions when the Canine Brief Pain Inventory is used to evaluate carprofen treatment for the control of pain and inflammation in dogs with osteoarthritis. Am. J. Vet. Res., 2013, 74(12), 1467-1473. [http://dx.doi.org/10.2460/ajvr.74.12.1467] [PMID: 24274882]

[489] Lascelles, B.D.; Knazovicky, D.; Case, B.; Freire, M.; Innes, J.F.; Drew, A.C.; Gearing, D.P. A canine-specific anti-nerve growth factor antibody alleviates pain and improves mobility and function in dogs with degenerative joint disease-associated pain. BMC Vet. Res., 2015, 11(1), 101. [http://dx.doi.org/10.1186/s12917-0150413-x] [PMID: 25926287]

[490] Hayashida, K. Substance P-saporin for bone cancer pain in dogs: can mans best friend solve the lost in translation problem in analgesic development? Anesthesiology, 2013, 119(5), 999-1000. [http://dx. doi.org/10.1097/ALN.0b013e3182a951a2] [PMID: 24195943]

[491] Walker, S.M.; Yaksh, T.L. Neuraxial analgesia in neonates and infants: a review of clinical and preclinical strategies for the development of safety and efficacy data. Anesth. Analg., 2012, 115(3), 638-662. [PMID: 22798528]

[492] Butt, M.T. Evaluation of the Adult Nervous System in Preclinical Studies. In: Fundamental Neuropathology for Pathologists and Toxicologists: Principles and Techniques; Butt, B.B., Ed.; John Wiley \& Sons, Inc.: Hoboken, NJ, USA, 2011; pp. 321-338. [http://dx.doi.org/10.1002/9780470939956.ch21]

[493] Westin, B.D.; Walker, S.M.; Deumens, R.; Grafe, M.; Yaksh, T.L. Validation of a preclinical spinal safety model: effects of intrathecal morphine in the neonatal rat. Anesthesiology, 2010 , 113(1), 183-199. [http://dx.doi.org/10.1097/ALN.0b013e3181dcd6ec] [PMID: 20526189]

[494] Yahalom, B.; Athiraman, U.; Soriano, S.G.; Zurakowski, D.; Carpino, E.A.; Corfas, G.; Berde, C.B. Spinal anesthesia in infant rats: development of a model and assessment of neurologic outcomes. Anesthesiology, 2011, 114(6), 1325-1335. [http://dx.doi. org/10.1097/ALN.0b013e31821b5729] [PMID: 21555934]

[495] Walker, S.M.; Grafe, M.; Yaksh, T.L. Intrathecal clonidine in the neonatal rat: dose-dependent analgesia and evaluation of spinal apoptosis and toxicity. Anesth. Analg., 2012, 115(2), 450-460. [http:// dx.doi.org/10.1213/ANE.0b013e3182501a09] [PMID: 22467896]

[496] Hamurtekin, E.; Fitzsimmons, B.L.; Shubayev, V.I.; Grafe, M.R.; Deumens, R.; Yaksh, T.L.; Walker, S.M. Evaluation of spinal toxicity and long-term spinal reflex function after intrathecal levobupivaciane in the neonatal rat. Anesthesiology, 2013, 119(1), 142-155. [http://dx.doi.org/10.1097/ALN.0b013e31828fc7e7] [PMID: $23514721]$

[497] Yaksh, T.L.; Rudy, T.A. Analgesia mediated by a direct spinal action of narcotics. Science, 1976, 192(4246), 1357-1358. [http:// dx.doi.org/10.1126/science.1273597] [PMID: 1273597]

[498] Yaksh, T.L.; Rudy, T.A. Chronic catheterization of the spinal subarachnoid space. Physiol. Behav., 1976, 17(6), 1031-1036. [http:// dx.doi.org/10.1016/0031-9384(76)90029-9] [PMID: 14677603] 